\title{
The natural and social production of a lake shore environment: The case of Erie and Presque Isle, Pennsylvania
}

Christopher R. Schaney
West Virginia University

West Virginia University

Follow this and additional works at: https://researchrepository.wvu.edu/etd

\section{Recommended Citation}

Schaney, Christopher R., "The natural and social production of a lake shore environment: The case of Erie and Presque Isle, Pennsylvania" (2010). Graduate Theses, Dissertations, and Problem Reports. 3237.

https://researchrepository.wvu.edu/etd/3237

This Dissertation is protected by copyright and/or related rights. It has been brought to you by the The Research Repository @ WVU with permission from the rights-holder(s). You are free to use this Dissertation in any way that is permitted by the copyright and related rights legislation that applies to your use. For other uses you must obtain permission from the rights-holder(s) directly, unless additional rights are indicated by a Creative Commons license in the record and/ or on the work itself. This Dissertation has been accepted for inclusion in WVU Graduate Theses, Dissertations, and Problem Reports collection by an authorized administrator of The Research Repository @ WVU.

For more information, please contact researchrepository@mail.wvu.edu. 


\title{
The Natural and Social Production of a Lake Shore Environment: The Case of Erie and Presque Isle, Pennsylvania
}

\author{
Christopher R. Schaney \\ Dissertation submitted to Eberly College of Arts and Sciences \\ at West Virginia University in partial \\ fulfillment of the requirements for the degree of
}

Doctor of Philosophy

in

Geography

\author{
Robert Q. Hanham, Ph.D., Chair \\ Robert Behling, Ph.D. \\ Kobena Hanson, Ph.D. \\ Richard J. Hoch, Ph.D. \\ Timothy A. Warner, Ph.D. \\ Department of Geology and Geography \\ Morgantown, West Virginia \\ 2010
}

Keywords: Presque Isle, Erie, Pennsylvania, Human Geography, Physical Geography, Historic Geography Copyright 2010 Christopher R. Schaney 


\title{
$\underline{\text { Abstract }}$ \\ Social Production of a Lake Shore Environment:
}

\section{The Case of Presque Isle, Pennsylvania}

\author{
Christopher R. Schaney
}

The objective of this research has been to combine geographic traditions of physical and human geography to investigate the role each play in the conceptualization of place utilizing the City of Erie and Presque Isle as a case study. From its inception, the economic structure associated with the City of Erie has been primarily centered on the presence of Presque Isle. Early industry focused on shipbuilding, shipping related to heavy industry. By 1907, the shipping industry at Erie was third largest on the Great Lakes, behind only Buffalo and Chicago. When the shipping industry began to wane in the mid to late $20^{\text {th }}$ Century, Presque Isle became a major recreation destination in Pennsylvania, hosting up to four million visitors each year. Throughout Erie's history, the unique natural presence of Presque Isle has fostered and continues to create economic opportunity. For this research, a narrative incorporating historic economic exploitation, from the incorporation of Erie, through the most recent economic transition from an industrial focus, which took place in the late 1970s and early 1980s, to one centered on a recreation driven service economy has been constructed in order to emphasize the interconnectivity of physical forces acting out on a land form and geomorphic influences on urban infrastructure and economic activity. In order to achieve this goal, this research has examined each of these phenomenon dependently in order to gain a more complete understanding of what constitutes place. 


\section{$\underline{\text { Dedication }}$}

$\underline{\text { To my Parents: }}$

Ray and Diana

To my Brother:

Nathan

To my Wife:

Mitzy 


\section{$\underline{\text { Acknowledgments }}$}

A dissertation is often viewed as a lonely exasperating task. Ultimately a dissertation has but one owner. However, there are times when an idea needs expansion or a concept needs refined. It is during these times when one reaches for the telephone, or pulls a knowledgeable and trusted colleague from important work and draws on expertise and sensitivity not otherwise available.

I am indebted to a number of people who have believed in my premises and offered invaluable assistance and advice, which has been instrumental in my ability to construct this dissertation, of which I am proud to have completed. Among them are my mentors and members of my committee, Chair, Dr. Robert Hanham whose insight and enthusiasm for this research has been an inspiration, Dr. Bob Behling, Dr. Kobena Hanson, Dr. Richard Hoch and Dr. Timothy Warner without their knowledge, enthusiasm and belief in my ideas, this would not be possible.

Also I would like to thank Dr. Richard Hoch for his patience and knowledge, allowing me to endlessly pick his brain for ideas and refinements. Additionally, I would like to thank Dr. Brent McCusker for lending his expertise and time in the unfortunate absence of Dr. Hanson during the defense of this dissertation. I would also like to thank my friends (Todd, Sam, Brian, Pat, Karen, Sarah, Walter to name a few) for keeping me sane through laughter and understanding during this difficult process. To all the graduate students, faculty and staff at West Virginia University Geology and Geography Department all of which together created the most enriching and fulfilling experience of my life.

Finally I owe a deep debt of gratitude to my wife Mitzy who has given encouragement, skillful editorial assistance and eternal patience throughout this process.

Thank you all, I would have never made it without you! 


\section{Table of Contents}

Abstract.........................................................................................................................................

Dedication ...................................................................................................................iii

Acknowledgments .................................................................................................................... iv

Table of Contents ................................................................................................................... v

List of Figures.............................................................................................................................. vii

Chapter 1: Introduction ............................................................................................................. 1

Chapter 2: Natural Processes and Place ..................................................................................... 9

Hydro-Climatological Impact on Lake Level ...................................................... 12

Storm Impact on Lake Level ............................................................................. 13

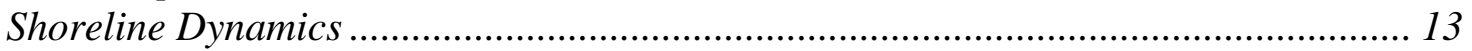

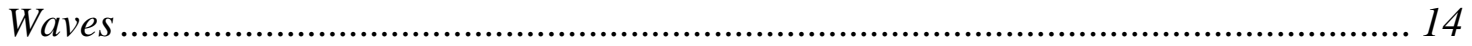

Longshore Drift............................................................................................. 14

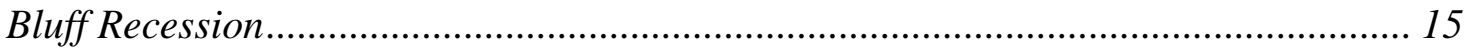

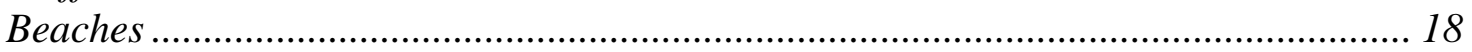

Chapter 3: Social Processes and Place .......................................................................................... 20

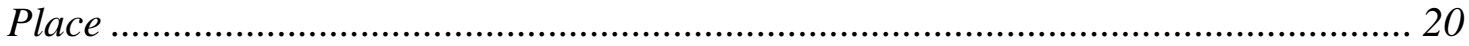

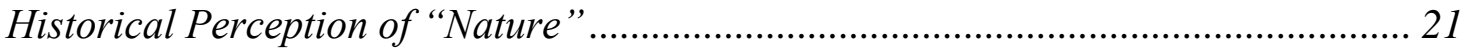

Structured Coherence ……………………………….......................................... 23

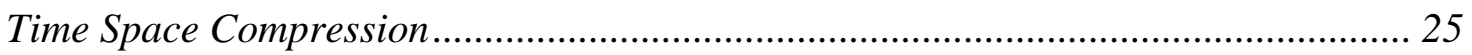

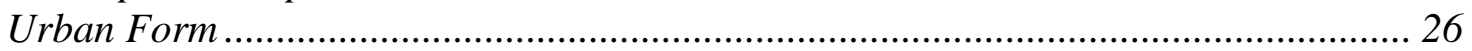

Socio-Spatial Practices and the Historic Construction of Place ................................... 30

Social Production of Nature .................................................................................. 33

Chapter 4: Industrial Era City of Erie / Engineering History......................................... 36

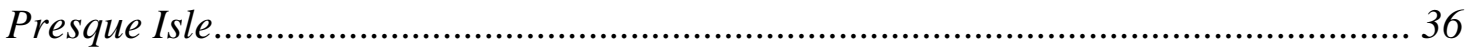

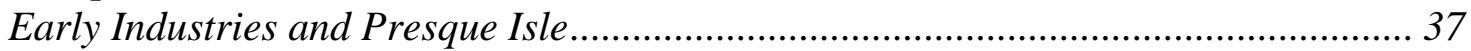

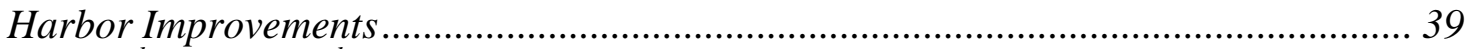

Mid-1 $9^{\text {th }}$ to Mid-20 ${ }^{\text {th }}$ Century Developments in Transportation ................................... 41

Presque Isle Migration and Early Breaches in the Neck.............................................. 43

Mid-19th - Early 20th Century Industry ................................................................ 47

Continued Breaches on Presque Isle ................................................................... 49

Mid-20 ${ }^{\text {th }}$ Century Developments in Transportation.................................................... 50

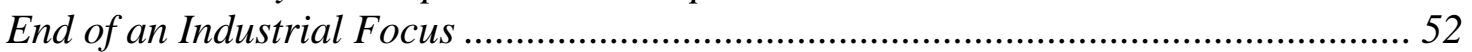

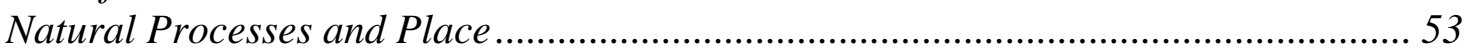

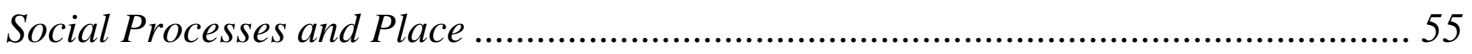

Natural / Social Interdependencies and Place.......................................................... 56

Chapter 5: Recreation Era City of Erie / Engineering History ...................................... 57

Recreational Beginnings......................................................................................... 57

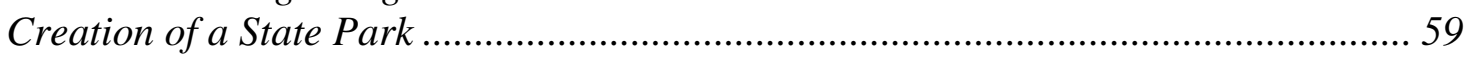

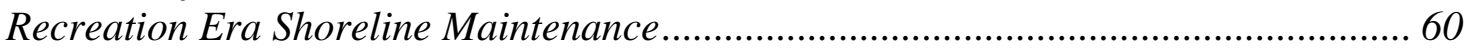

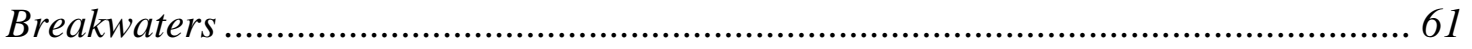

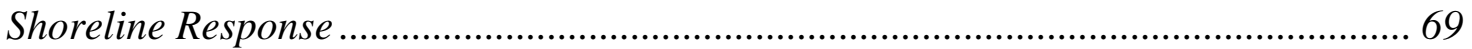

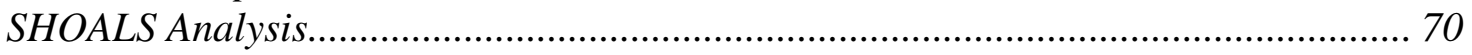

Focus on Recreation Driven Service Activity ......................................................... 74

Natural Processes and Place ............................................................................. 90

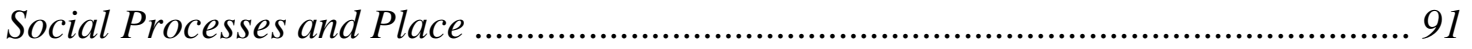


Natural-Social Interdependencies and Place ............................................................. 92

Chapter 6: Conclusion ................................................................................................................. 94

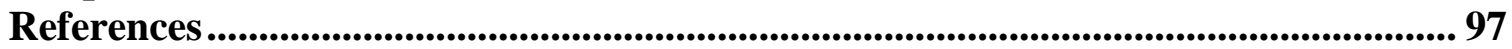

Appendix A ................................................................................................................................... 104

Scanning Hydrographic Operational Airborne Light Detection and Ranging Survey (SHOALS)

Appendix B ...................................................................................................................... 105

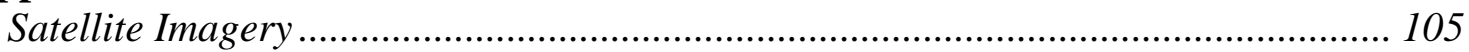

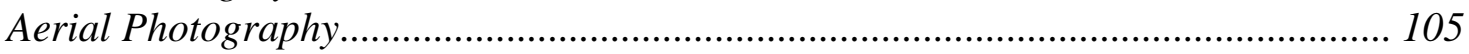

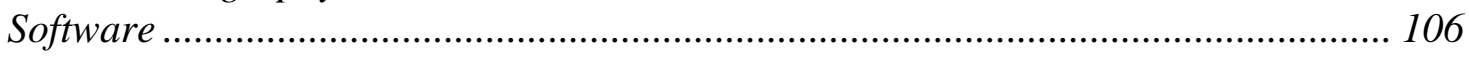




\section{List of Figures}

Figure 1: Map of Presque Isle produced by USACE, Buffalo District, highlighting beaches ponds and harbor entrance (Gorecski and Pope, 1993) ...................................... 5

Figure 2: Western Pennsylvania Counties and Major Urban Centers. ............................... 6

Figure 3: Map of the Laurentian Great Lakes (Ballert, 1953) ....................................... 10

Figure 4: Historic map illustrating the natural entrance to Presque Isle (no scale or original date of publication given) (Swisher, 1979) (Schaney, 2003)........................... 38

Figure 5: Entrance to the harbor as illustrated in a PA Map image acquired 2005 (www.pasda.psu.edu). Inset is an artist rendering of the harbor entrance 1836 (Swisher, 1979).

Figure 6: Digitized shorelines of 1819, 1839 and 1865 overlaid on a 2002 aerial photography mosaic documenting the eastward migration of Presque Isle (Schaney, 2003).

Figure 7: Digitized shorelines of 1888 and 1907 overlaid on a 2002 aerial photography mosaic documenting the eastward migration of Presque Isle (Schaney, 2003). 46

Figure 8: Digitized 1839 shoreline overlaid on a 2002 aerial photography mosaic illustrating second breach in the neck of the peninsula (Schaney, 2003)...................... 48 Figure 9: Location of three proto-type breakwaters at beach 10 (Gorecki and Pope, 1993).

Figure 10: Map of Presque Isle produced by U.S. Army Engineers Buffalo District, highlighting 58 segmented rubblemound breakwater position and construction (Gorecski

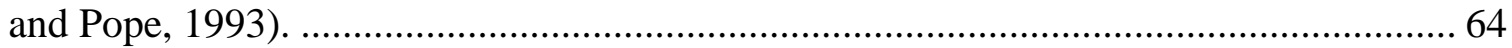

Figure 11: Creation of tombolos shoreward of the breakwaters along the peninsula shoreline (Schaney, 2003).

Figure 12: Shoreline bathymetry of the neck of the breakwater system (mainland connection - 20) (Mohr et al, 1999). 72

Figure 13: Shoreline bathymetry of the apex of the breakwater system (23-40) (Mohr et al, 1999).

Figure 14: Shoreline bathymetry of the terminus of the breakwater system (40-58) (Mohr

et al, 1999).

Figure 15: Aerial photography from 1970, 1983 and 1987 illustrating the transition from industrial to recreational usage of the harbor (www.eros.usgs.gov).

Figure 16: Aerial photography from 1993 and 2006 illustrating the transition from industrial usage to recreational usage of the harbor (www.pasda.psu.edu).

Figure 17: Aerial photography from 1977 illustrating major areas of service along the I79, 90 and Peach corridors (www.eros.usgs.gov).

Figure 18: Aerial photography from 1983 illustrating major areas of service along the I79, 90 and Peach corridors (www.eros.usgs.gov).

Figure 19: Aerial photography from 1993 illustrating growth of major areas of service

along the I-79, 90 and Peach corridors (www.pasda.psu.edu). 82 Figure 20: Aerial photography from 2005 illustrating growth of major areas of service along the I-79, 90 and Peach corridors (www.pasda.psu.edu)...................................... 83 Figure 21: Study Area..................................................................................... 84

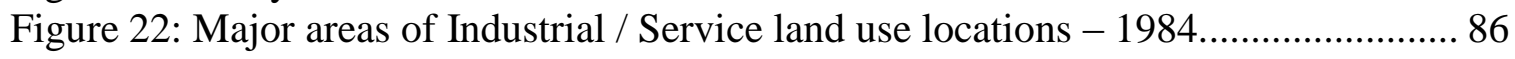
Figure 23: Major areas of Industrial / Service land use location -2007 ......................... 88 Figure 24: Mean center of Industry / Service 1984 / 2007. .......................................... 89 


\section{Chapter 1: Introduction}

For the purposes of the research, place is referred to as a physical setting within which economic activity and social interaction take place. Place is not a rigid unevolving feature, rather it is created and reproduced by continuous social utilization of a physical setting. A major component of this research will investigate the interplay of physical and social processes and the role the two play in the production of place. The construction of place is designed to express the inevitability of the social relationship with nature by uncovering the domination of nature manifested by capitalist modes of production and the romanticized response to the domination of nature by society (Smith, 1996). Understanding the role these two processes play will not only allow for a greater understanding of how place is produced, but also reproduced in the wake of economic transition or crisis.

Little has been done in recent geographical research that ties physical process with social processes with concern to our understanding of the nature of place. In an attempt to gain a more complete understanding of social and physical structures found within historical geographical research, a theoretically informative narrative has been constructed, designed to apply and synthesize a range of social and physical conceptualizations relating to the changing nature of those structures within a historically specific context.

Conceptualizations used in this narrative are found within the broader disciplines of human and physical geography. Although historically linked, they have since 
diverged. It is the intent of this research to link these traditions in order to achieve a more holistic understanding of the production of space as it is manifested in place. The separation of human geography from physical geography is a relatively recent

development within the greater context of geographical research. As late as the early $20^{\text {th }}$ Century, human geography was intertwined with physical geographical concepts with emphasis on human - environmental relationships (Johnston, 2000). However during the 1960s and 70s, an adoption of a quantitative revolution and the related sub discipline of spatial science, promoted a direction in human geography concentrated on models of socio-economic systems. The adoption of spatial science had the effect of splintering the relationship between human and physical geography into two distinct schools (Johnston, 2000).

In reaction to the adoption of spatial science, geographers began to critique the influences of the quantitative revolution and its failure to recognize individual humans in and their attitudes, feelings and values associated with sense of place. In response, place, or the setting for which social relations are identified and played out, became an important geographical conceptualization within the field of human geography. Place, manifested itself in the discipline through investigations by Agnew (1987) and Johnston (1991), among others, through major elements of; 1) locale, the setting for with social relationships take place, 2) location, the geographical area for which social interaction takes place within a wider social and economic framework, and 3) sense of place, from a greater regional perspective (Agnew, 1987; Johnston, 1991).

Other conceptualizations put forth by Harvey $(1985 ; 1987 ; 1990 ; 2002 \mathrm{a} ; 2002 \mathrm{~b}$; 2003) investigate place in context of the effects of time space compression, structured 
coherence, urban form and the geographically uneven effects of globalization. Massey $(1993 ; 1999 \mathrm{a} ; 1999 \mathrm{~b})$ furthered the understanding of place by drawing attention to specificity or uniqueness of place while recognizing the wider processes operating at a global scale. Massey identifies theorizations of wider processes while also recognizing the uneven effects caused by the particularities of specific places and their unique histories within the context of larger regions (Duncan, 2000).

Historically, physical geography has been concerned with the description of the earth; its landforms and processes, floral and faunal inhabitants, the distribution of its inhabitants and the causes of those distributions (Goudie, 2000). More recently, contributions by Innes (1992), Thomas and Middleton (1994) and Williams et al (1998) to the field of physical geography have become more focused on human impacts on environment including; forest decline, desertification and climate change with concern to global climate change. Other applications within the field of physical geography include a link to societal needs through environmental management of water recourses and coasts, as well as hazards and disaster research. Recently, a move has been put forth to redefine physical geography as to be concerned with: 1) the identification and description of biochemical components in the environment, 2) the spatial and temporal interpretation of environmental systems and 3) determination of the resilience of environmental systems in response to various disruptions including human activity (Goudie, 2000).

The objective of this research is to combine the above geographic traditions of Physical and Human Geography to investigate the role each play in the conceptualization of space through an understanding of place utilizing the City of Erie and Presque Isle as a case study. Erie, founded in 1795, situated in the northwest corner of the Commonwealth 
of Pennsylvania (Pennsylvania) is located adjacent to Presque Isle Peninsula, a significant coastal feature on the south shore of Lake Erie (Figures 1 and 2). Geomorphology associated with Presque Isle is dynamic, and consequently erosion and re-deposition continuously alter the landform. In response, there has been a wide range of stabilization attempts by government agencies, in particular the United States Army Corps of Engineers (USACE) and Pennsylvania (Pope and Gorecski, 1982).

From its inception, the economic structure associated with the City of Erie is primarily centered on the presence of Presque Isle. Early industry focused on shipbuilding, shipping related to heavy industry such as iron ore, coal, and salt, and the mining and transportation of sand and gravel deposits (MacDonald and Frew, 1996). By 1907, the shipping industry at Erie was third largest on the Great Lakes, behind only Buffalo and Chicago. When the shipping industry began to wane in the mid to late $20^{\text {th }}$ Century, Presque Isle became a major recreation destination in Pennsylvania, hosting up to four million visitors each year. Throughout Erie's history, the unique natural presence of Presque Isle has fostered economic activity. This research has been designed to illustrate the changing relationship between economic exchanges, found within a capitalist framework, exploiting the presence of Presque Isle through the last economic transition from an industrial focus, which took place in the late 1970s and early 1980s, to one centered on a recreation driven service.

The ability to adapt to changing economic patterns and reproduce structured coherence has been largely accomplished by the presence of Lake Erie and more specifically Presque Isle Peninsula. Because of the inter-connectivity of physical forces 


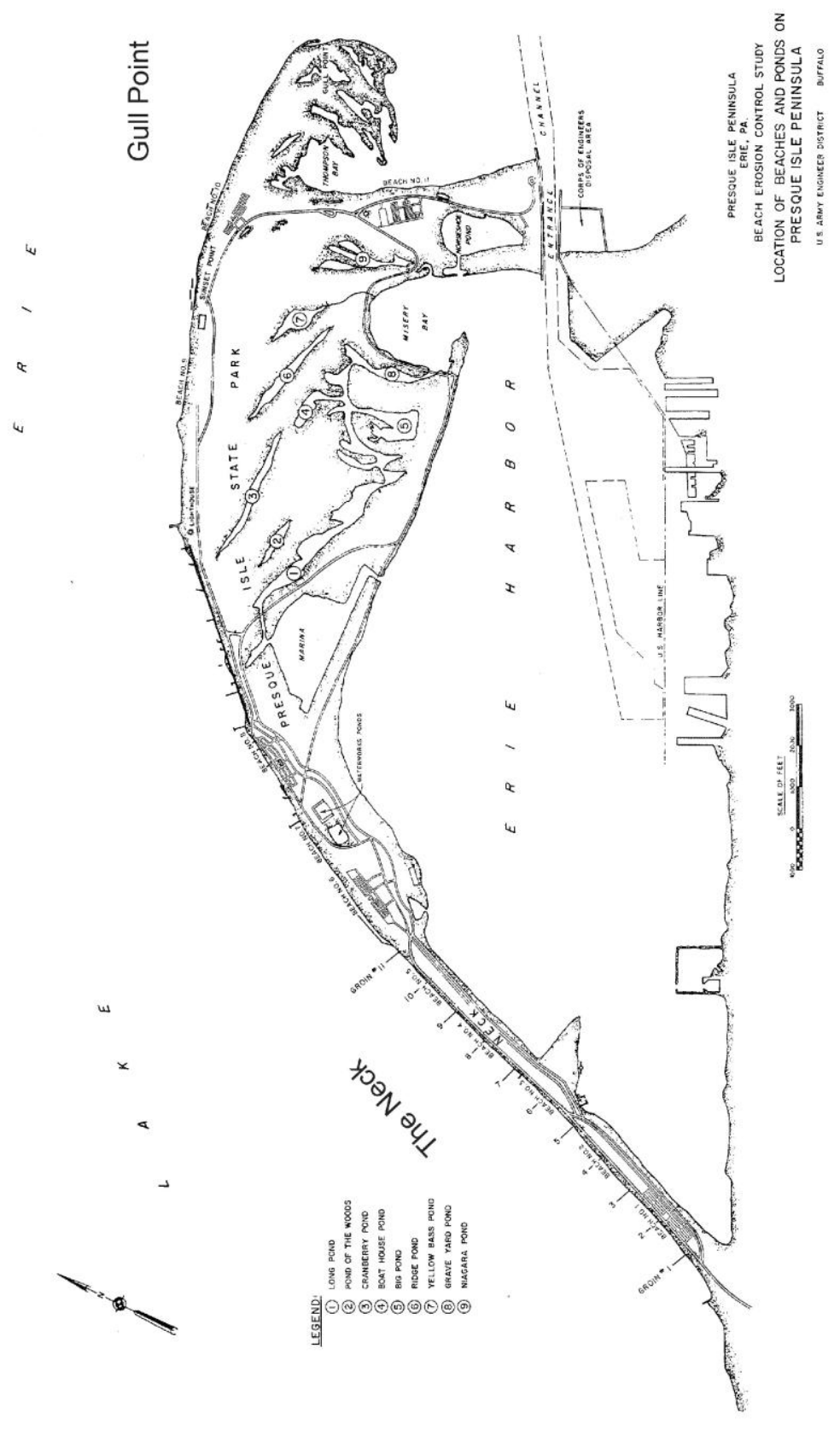

Figure 1: Map of Presque Isle produced by USACE, Buffalo District, highlighting beaches ponds and harbor entrance (Gorecski and Pope, 1993). 


\section{Western Pennsylvania Counties and Major Urban Areas}

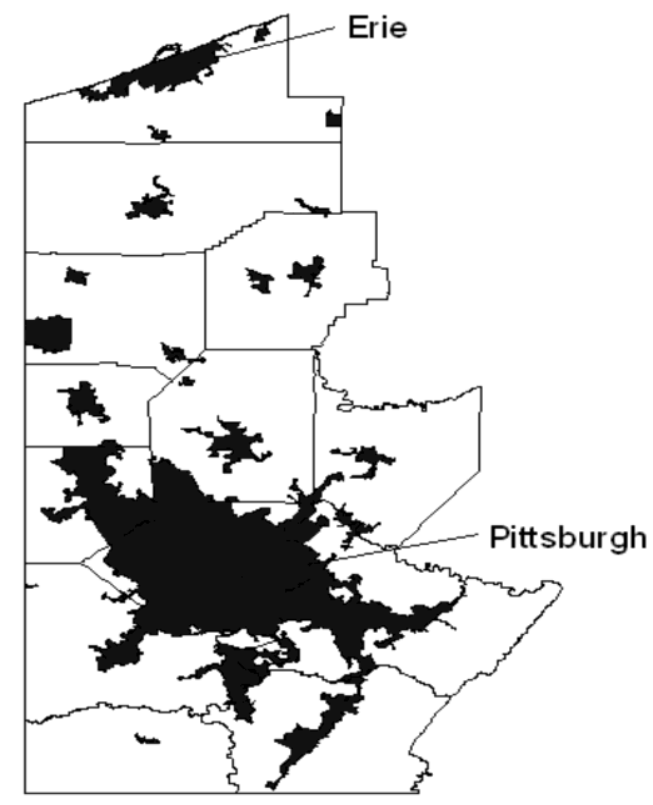

30

30

60 Miles

\section{Counties}

Urban Areas

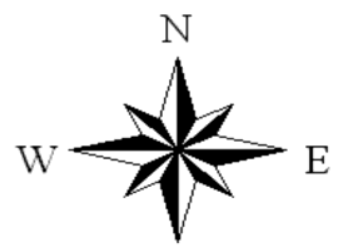

$\mathrm{S}$

Figure 2: Western Pennsylvania Counties and Major Urban Centers. 
and urban infrastructure, this research will examine each phenomenon in order to gain a more complete understanding of what constitutes place.

The ontological position of this research is one that identifies nature as a socially produced environment constructed with the intention of serving social interests. In the case of Presque Isle associated with the City of Erie, understanding what constitutes place cannot be removed from a discussion of issues associated with society - nature relations. Comprehension of place will be investigated within the greater context of the interconnectivity of social relations within a capitalist economic framework of various forms of production and consumption.

Changes in the economy from an industrial base to one focused on recreational driven service have not only altered the structure of the urban environment, but also the role that Presque Isle and the harbor play within the new economy. The changing role of the peninsula has also had a dramatic effect on how the peninsula shoreline has been used and maintained. This research utilizes remote sensing technologies together with geographical theories concerning the construction of place as a way to identify physical changes in the landscape and illustrate social forces at work in the region that have shaped those changes.

A unique challenge of this research has been to construct a theoretically informed narrative illustrating place that is both historically and geographically specific, a contextually dependant phenomena, manifested in a specific location (Sayer, 1989). Improvement of our understanding of locality with concern to this research has been to create a narrative which situates place in a concrete space - time setting. Construction of the description of place includes studies of generally accepted stages in the development 
of capitalism that have originated in specific geographical and historical circumstances, which continue to develop in ways that bear the imprints of the geo-historical contexts in which they are found (Cusmano, 1985; Littler, 1982; Sayer, 1986; Urry, 1986). In addition, the narrative incorporates place specific physical geomorphic processes that have not only complemented historic capitalist activity but have also contradicted continued capitalist progress.

Inspiration for constructing this narrative has been taken from initial investigations of the City of Erie and Presque Isle in conclusion of my Master's Thesis completed 2003. For that research, I examined the glacial / geomorphic history of Presque Isle, industrial and economic history of Erie, and the history of engineering practices associated with stabilization and maintenance activities conducted by USACE. These histories were applied within the context of remote sensing techniques and methodologies in and effort to illustrate west to east migration of the peninsula using historical aerial photography. As with many instances of initial research, I was compelled to a more complete appreciation and application of conceptualizations found within the field of geography that would allow a greater understanding of the complex relationship between physical and human geography and the creation of place. In an effort to achieve this goal, I have placed brief summarizations of Erie history taken from my Master's Thesis and incorporated them within the conceptually informed narrative into the Chapters Four and the beginning of Chapter Five. These brief summarizations, which I have cited from my previous research, are designed to illustrate this long term socio-environmental relationship, and provide context for understanding the last economic transition from industry to service. 


\section{Chapter 2: Natural Processes and Place}

Information compiled for this chapter has been designed to conceptualize natural lake processes associated with the Great Lakes with specific reference to Lake Erie and Presque Isle, adjacent to the City of Erie. This chapter is designed to illustrate the role physical processes play in the creation and evolution of place. Within this chapter, processes associated with lake level, shoreline dynamics and bluff recession will be investigated in order to identify underlying activities associated with landform creation, migration and stabilization. Understanding lake process and associated evolution of shoreline position on Presque Isle will enable this research to express the social relationship with nature by uncovering the domination of nature manifested in capitalist modes of production.

The Laurentian Great Lakes (Figure 3), which include Superior, Michigan, Huron, Erie, Ontario, Georgian Bay and Lake St. Clair comprise the United States' premier surface water resource, with a basin area of 770,000 kilometers $^{2}\left(\mathrm{~km}^{2}\right)\left(300,000\right.$ miles $^{2}$ $\left.\left(\mathrm{mi}^{2}\right)\right)$ (Assel et al, 2004). The combined length of the Great Lakes coastline is greater than 15,000 kilometers $(\mathrm{km})(9,321$ miles (mi)), the longest in the nation. These lakes provide about 18 per cent of the world's freshwater supply and approximately 80 per cent of the water supply for the United States. In addition to supplying over 40 million people with water, the Great Lakes also support recreational activities, a 1,931 km (1,200 mi) commercial shipping route, industry, commercial navigation and fish and wildlife habitats (Assel et al, 2004). 


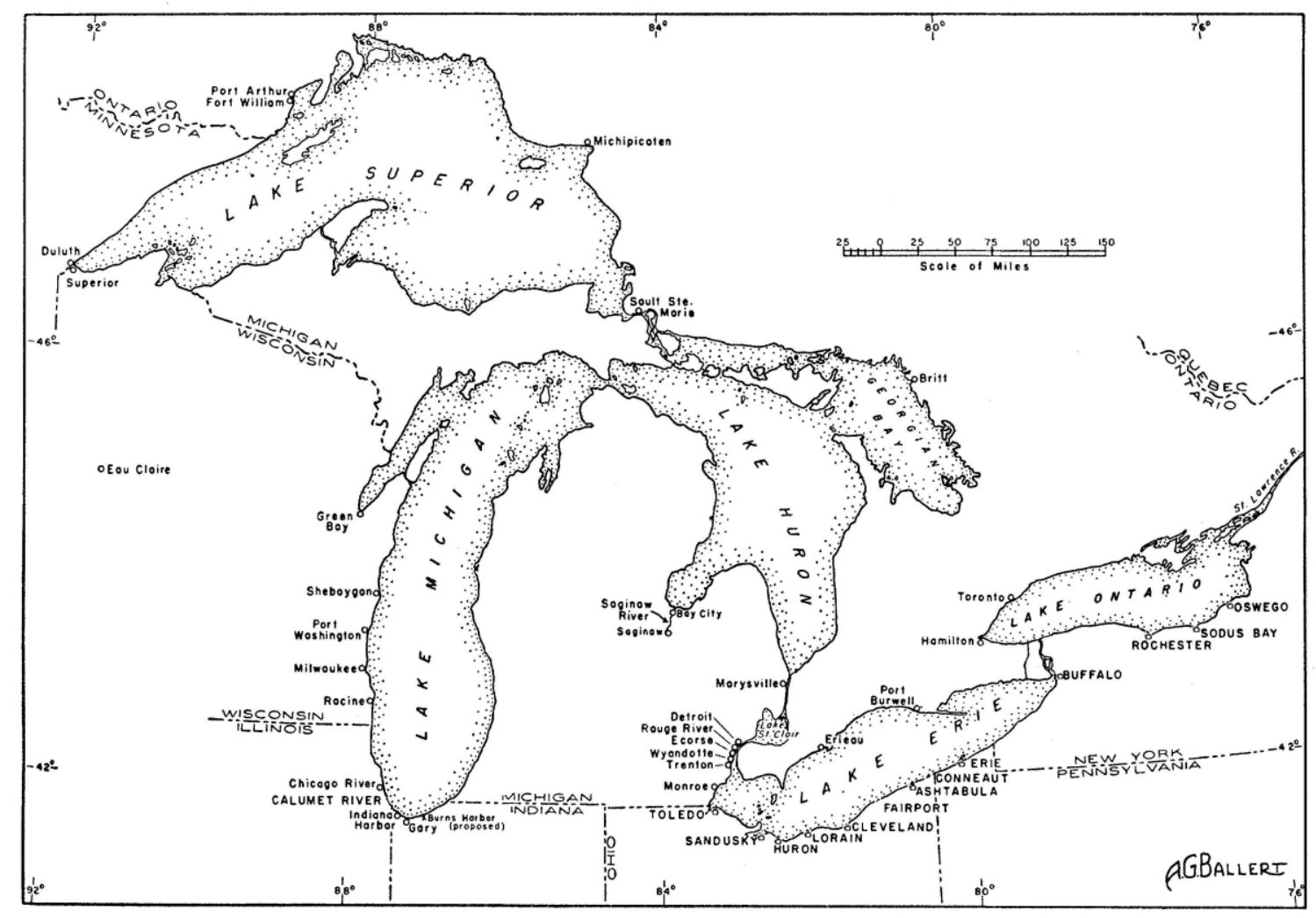

Figure 3: Map of the Laurentian Great Lakes (Ballert, 1953) 
For the purposes of this research, Lake Erie level and associated coastal zone erosion and deposition will be the primary focus of coastal zone processes. The coastal zone is defined as the shoreline, beach, and bluffs. These three areas were included in the coastal zone because each plays a major role in shoreline morphology. Lake Erie's coastal zone is a dynamic area in constant motion. The coastal zone is an exceedingly complex area with three primary factors determining erosion rates; lake level, wave energy and shore material composition (Carter et al, 1987). Lake level, including closely associated wave energy, is the most dominant factor affecting coastal zone erosion. During times of high lake level beaches narrow, lowering the amount of energy needed to reach the shore increasing the amount of erosion. During times of low lake level, beaches widen, increasing the amount of wave energy needed for shoreline erosion. The resistance of material making up the shore, as well as closely associated wave energy, are other important factors determining shore erosion rates (Carter et al, 1987).

The lakes and their connecting channels are naturally well regulated due to the large lake surface areas and narrow outlets. Lakes Superior and Ontario are artificially regulated. Natural and artificial regulation have resulted in a relatively small range of fluctuation, about 1.8 meters (m) (6 feet (ft)) (Assel et al, 2004). Water is removed from Lake Erie by the outflow of the Niagara River, evaporation from the lake surface, groundwater seeping out of the lake, and artificial diversions out of the lake, such as the Welland Canal and municipal and industrial intakes. Hydrologic factors of water gain and loss are measurable and excesses in one way or another cause lake level to rise or fall (Carter et al, 1987). 


\section{Hydro-Climatological Impact on Lake Level}

The greatest long-term and seasonal variation of lake level is precipitation (Assel et al, 2004). There is a seasonal time lag between precipitation highs and lows and associated changes in lake level. High lake levels, usually in June and July, occur as a result of an increase in precipitation and groundwater input due to typically higher rainfall in the spring. Low lake levels, in December and January, occur due to lower levels of precipitation in summer and fall. Along with seasonal variations in lake level, there are also cyclical variations in the lake based on prolonged drought or prolonged periods of above normal precipitation. Because of cyclical changes in lake level, although not continuous, Lake Erie water levels were high from the late 1960s until the late 1990s with records set in 1973 and 1986. Historically, major low levels occurred in the 1930s, the mid-1950s and the late 1980s (Assel et al, 2004). Long term lake level decline between 1954 and 1997 demonstrated the drop in level was primarily driven by greatly decreased run-off and high lake evaporation due to higher air temperatures (Assel et al, 2004). The El Niño in the late 1990s with low snow-pack, record low ice cover, and high evaporation due to higher air temperatures continued a cycle of record decline in lake level that continues to the present. As of November 2007, outflow from the lake into the Niagara River was below average in November. Forecasted water levels through May 2008 will remain 20 to 33 centimeters (cm) (8 to 13 inches (in)) below long term average and 38 to $56 \mathrm{~cm}$ (15 to 22 in) below last year's levels, but well above record lows (USACE, 2007). 


\section{Storm Impact on Lake Level}

Storms and wind generated by high and low pressure systems that travel along the greatest axis of the lake cause major, rapid, short-term changes in lake level. Most of the energy that is spent in the shore zone is conveyed by wind generated waves on the water surface (Bloom, 1991). The intensity of waves generated by wind is dependent on wind speed, duration, and fetch (for Lake Erie, wind is predominantly from west to east). The effect of storm winds on the lake surface transports large volumes of water in the direction the wind is blowing resulting in a storm surge. Storm surges formed by wind driven waves raise the level of the lake, with the most dramatic effects at its eastern and western ends (Carter et al, 1987). The surge is often responsible for the creation of a seiche or back and forth oscillations of water level in enclosed or semi-enclosed basins (Ritter et al, 1995). The initial and hence greatest rise in lake level along with accompanying large waves inflicts the most damage along the shore. After the initial surge, the oscillations gradually decrease until the original equilibrium level is reached (Ritter et al, 1995).

\section{Shoreline Dynamics}

The shoreline is characterized by the line of demarcation between land and water. The shore zone (the zone affected by wave action) has been subdivided into; offshore, the shallow bottom seaward of the breaking waves; nearshore, between the breaker zone and the low tide level; foreshore, which extends from the low tide level to the limit of high tide, storm wave effects; and backshore, from the limit of frequent storm waves landward to the base of a cliff, dune, beach ridge or permanent vegetation (Bloom, 1991) 


\section{Waves}

Waves are responsible for most erosion, sediment transport and deposition in coastal areas (Monroe and Wicander, 2006). One of the most crucial influences on coastal dynamics is wave height (Carter et al, 1987). Wave height has a large effect on shoreline erosion rates and is reliant on wind speed, duration and fetch. Wind is the connection that converts solar energy to wave energy (Bloom, 1991). Although winds can blow out of the east, the prevailing winds for Lake Erie generally blow out of the west parallel, to the greatest amount of open water, resulting in large wave energy at most commonly the western end of Lake Erie (Carter et al, 1987). Waves become a geomorphic agent when wave velocity begins to decrease due to bottom friction (Bloom, 1991). Contact with the bottom causes waves to refract from an oblique shoreline approach to more parallel to the shoreline (Monroe and Wicander, 2006).

\section{Longshore Drift}

Although waves are refracted and break nearly parallel to the shoreline, they most often reach the shoreline at some angle (Monroe and Wicander, 2006). The angle waves break on the shoreline cause the water between the breaker zone and the beach to flow parallel to the shoreline. Allowing a longshore current to develop which flows in the same direction as the approaching wave. Longshore currents flow parallel to the shoreline and expend energy in the transport and deposit of sediment in the nearshore zone. The oblique angle waves strike beaches cause sediment to move up the beach face at a similar angle. However as the sediment is carried seaward by the backwash, the sediment moves perpendicular to the shoreline. As a result, sediment moves along the 
beach in a zigzag pattern in the direction of longshore current (Monroe and Wicander, 2006).

Longshore drift on Lake Erie with concern to sediment deposition on Presque Isle moves in a west to east direction. For general lake processes, from Cleveland, Ohio east, longshore drift is predominantly west to east (Carter et al, 1987). West of Cleveland, longshore drift is reversed from east to west. This is due to winds that blow out of the east generate larger and more powerful waves as a result of greater fetch. These differences translate into less frequent longshore sediment transport to the west (Carter et al, 1987).

\section{Bluff Recession}

Coastal recession is a foremost geologic process in the United States where it is estimated that 75 per cent of shorelines are undergoing recession (Pilkey and Thieler, 1992). Lake Erie is $338 \mathrm{~km}$ (210 mi) long by $92 \mathrm{~km}$ (57 mi) wide with a total shoreline length of $1400 \mathrm{~km}$ (870 mi), including islands (Dawson and Evans, 2001). The Pennsylvania shoreline of Lake Erie is approximately $70 \mathrm{~km}$ (44 mi). Studies on the Ohio shoreline recession rates investigated by Guy (1995) indicated that 90 per cent of the bluffs are experiencing recession at an economic loss of 10 million dollars per year. Approximately 1.6 million metric tons of sediment is eroded each year, 80 per cent of which is fine grained sediment deposited in deep water offshore (Guy, 1995)

The bluffs, where most beach material is derived, are composed of primarily three layers. The lowermost, first layer underlying the unconsolidated bluff strata is ancient (Devonian age) bedrock consisting of alternating layers of shale and very fine-grained 
sandstone (Buyce, 2005). To the east of the peninsula this bedrock forms the lower portion of the bluffs, armoring the slopes from the effect of wave educed erosion. Directly above the bedrock is, up to $10 \mathrm{~m}(31 \mathrm{ft})$ of poorly sorted impermeable glacial silt and clay (diamict), which, west of the peninsula, constitutes the lower portion of the bluff. The upper portion of the bluff is comprised of up to11 m (33 ft) of permeable glacial lake sands (Buyce, 2005).

In large part, mass wasting events along the coastal bluffs of Lake Erie west of the peninsula are the product of wave action (Vallejo and Degroot, 1998). Lake level is directly responsible for the ease at which wave action reaches the bluff face. Wave action on the lowermost strata of diamict west of the peninsula is the principle mechanism for increasing the steepness of the bluffs (Carter et al, 1987). During a period of high lake level, the erosion rate of bluffs increase because beaches are narrow. The diminished beaches allow storm driven waves to easily reach the toe of bluffs. During low water the opposite effect is true. The erosion rate decreases due to a wider beach zone in which the waves expend their energy before reaching the bluff face. Although wave action on the toe of the bluffs is believed to be the most important factor influencing changes in bluff geometry, other factors affecting slope geometry include; bluff composition and groundwater (Vallejo and Degroot, 1988).

When waves strike the toe of the bluffs, two interdependent forces act on the bluff face; normal force pressure and tangential force shearing (Vallejo and Degroot, 1988). Normal force pressure expends wave energy perpendicular to the face. Tangential force shearing is exerted during the washout process removing material from the toe of the bluff. The effects of normal wave loads cause a decrease in the strength of cohesive soils 
increasing its susceptibility to erosion by running water. Tangential forces remove the weakened soil during the washout process (Vallejo and Degroot, 1988).

Changing wave energy on the toe of the slope, driven by changing lake level, affects the balance between erosion and the resistance of materials that comprise the bluffs. Mass wasting or bluff recession occurs as the slope adapts to the new energy conditions imposed on it, and will continue until the bluffs regain equilibrium (Vallejo and Degroot, 1988).

According to Vallejo and Degroot (1988), there are three types of wave energy conditions at work on the toe the slope; strong toe erosion, moderate toe erosion and no toe erosion. During strong toe erosion, the bluffs are over steepened by strong wave action. As a result, the bluffs fall out of equilibrium. In order to achieve balance, the slopes fail, most commonly in a rotational slide, in an attempt to regain a natural angle of repose. Once the bluffs fail, waves remove the material accumulated at the toe of the bluff (Vallejo and Degroot, 1988).

During moderate toe erosion, waves do not remove intact material from the toe of the bluff. The only wave energy expended on the bluffs is the removal of prior failures accumulated at the toe (Vallejo and Degroot, 1988). The effect on the slopes is that they are not over steepened. Unaided slope processes take over and a slow parallel retreat occurs (Woodroffe, 2003).

No tow erosion takes place when lake level reduces, resulting in waves that break at long distances from the shoreline (Vallejo and Degroot, 1988). During this period, toe erosion, as well as the removal of weathered material at the toe ceases allowing weathered material to accumulate at the toe of the slope (Woodroffe, 2003). If 
accumulation of weathered material continues to build up the slope will stabilize and evolve into a natural angle of repose.

\section{Beaches}

Beaches are deposits of unconsolidated material which extend from low tide water line landward to a change in topography or permanent vegetation (Monroe and Wicander, 2006). Most of the material that comprises the beaches on Lake Erie are derived from bluff recession or redistributed sediment along the shoreline by longshore currents (Carter et al, 1987). Very little material from streams and rivers contribute to Lake Erie beach material. Due to embayments at the mouths of tributary streams and rivers, most of the material transported drops out upstream of the mouth due to the loss of stream flow energy (Pope and Gorecski, 1982).

Beach profiles are most dramatically changed during storms. Beaches are narrower and steeper during and after storms (Carter et al, 1987). Because of the increase in wave energy, sand sized grains are swept offshore and deposited on the nearshore bottom. Once wave energy weakens, the sand from the nearshore is carried back on shore by the processes of longshore drift. Other common factors that dictate beach profile include waves, lake level, sand supply and beach gradient (Carter et al, 1987).

In this chapter, natural processes have been examined in order to gain insight into the creation of the lake shore environment associated with Presque Isle and the City of Erie. Understanding these processes provides knowledge into activities carried out by a number of state and federal agencies in order to stabilize and maintain the physical landscape. Additionally, natural processes have been examined to provide insight into 
the complexities of the social relationship with nature. Understanding the role of physical processes within a historical context will allow for conceptualization of space and place from a perspective of the creation and evolution of a landform specifically designed to serve social interest through the creation of a profit driven landscape. 


\section{Chapter 3: Social Processes and Place}

Information for this chapter has been designed to conceptualize social processes and the production and evolution of space through an understanding of the impacts of capitalism with regard to the City of Erie. The effects of capitalist activity are examined from a dual perspective of the of the built environment that address socio-economic activity, as well as the commodification of landscapes historically constructed and reconstructed in particular profit motivated ways. Within this chapter, incorporation of landscape modification through capitalist activity has been illustrated through an examination of generally accepted conceptualizations of space and place. This framework enables a greater understanding of landscape modification by capitalist activity. In addition, historical perceptions of nature as well as the social production of nature have been conceptualized in order to gain insight into changing attitudes toward nature, as the construction of place evolves within particular location.

\section{Place}

This research has been conducted from a theoretical foundation in which place is referred to as a setting for economic activity and social interaction at a particular location constituted out of an assemblage of buildings, land use patterns and arteries of communication and commerce (Pred, 1984). In this instance, place is not a rigid unevolving feature, rather it is created and reproduced by continuous social utilization of a physical setting. Whether a village or metropolis, place is not constructed in isolation. Understanding the evolution of place from a historical perspective provides meaning on 
how the global capitalist system has grounded itself and acted out in a specific location (Merrifield, 1993). Hence the space of the whole (global capitalist system), derives its meaning through place.

Within the greater concept of space and place, social capitalist space represents a fluidity of material flows such as commodities, money, and information which is comprised in a network of exchange and a flow of resources (Merrifield, 1993). In order for capital to flow through a network, capital must fix itself in the landscape which manifests itself as the built environment. However, there exists, several contradictions, discussed in greater detail below, that undermine capital fixity such as time space compression, accumulation and expansion of the economy, and class struggle within a territory that break down and weaken capital fixity in the landscape. As a necessity, capital fixity and the creation of the built environment emerge as a stopping point or as a specific moment in the dynamic of capitalist social space (Merrifield, 1993). Within this capitalist framework, the fixity of capital and the creation of place becomes the landscape where "social practices of consumption, enjoyment, tradition, self identification, solidarity, social support, and social reproduction are lived out" (Merrifield, 1993). Place, born out of capitalist space, is where everyday life is positioned.

\section{Historical Perception of "Nature"}

Even though there is an extensive history of evolution of Presque Isle as a socially produced second nature, there is a continued perceived autonomy from the commodification of the peninsula. Popular perception of the peninsula is more in line with external or universal conceptualizations of nature. These conceptualizations are not 
new in the field of geography or with environmentalists concerned with preservation. It is however, my intention with this research to demonstrate continued production and reproduction of structured coherence of the City of Erie is dependant on the dichotomy of a real verses perceived nature associated with Presque Isle.

Each of the discussions on external and universal conceptions of nature illustrated below contain within them contradictions that are each broken into two perspectives. Smith (1984) demonstrated the evolution of the conception of an external view of nature. The first theoretical position viewed the wilderness as the antithesis of civilization. The wilderness was viewed as an obstacle to overcome and conquer in path to progress and civilization. However, once the wilderness was perceived to be tamed, a second perspective of external nature evolved. Put forth by disjointed city dwellers removed from natural environments, a romanticized view of nature developed. From this romanticized view, a "back to nature" movement developed which viewed social infringement on the natural world as inherently negative (Smith, 1984). From the back to nature perspective, nature was viewed as something to be celebrated as sanctuary or retreat from the everyday stresses of society (Smith, 1996). This conception of nature positions human beings against a rapidly disappearing non-social world that is in need of protection from an encroaching social destruction or alteration of the natural world (Castree, 2001).

From the universal perspective, nature has been viewed as evidence of an inherently virtuous, dignified form of deeper spiritual meaning (Smith, 1984). Emerson, as found in Smith (1984) demonstrates this sentiment writing;

\footnotetext{
"The noblest ministry of nature is to stand as the apparition of God. It is the organ through which the universal spirit speaks to the individual and strives to lead back the
} 
individual to it. Man is nature's head and heart, and finds something of himself in every great and small thing, in every mountain stratum, in every new leaf of color, fact of astronomy, or atmospheric influence which observation or analysis lay open" (Smith, 1984).

From this perspective, man and nature are seen as a harmonious entity that cannot be distinguished from one another. However, a contradiction developed from the initial external position that viewed nature as a wilderness as the antithesis of civilization, to a universal position that viewed nature in harmony with society. From this contradiction the universal conception of nature is viewed as a garden in need of tending in order to bring it on-line with human / social experience.

Popular perception of Presque Isle is based in the above external / universal framework. From these theoretical positions, the push and pull between the universal / external debate has influenced the direction of the social production of the peninsula. This debate has resulted in an evolution of stabilization / manipulation efforts in line with the populist perception of nature.

\section{Structured Coherence}

Harvey defines structured coherence as "the forms and technologies of production (patterns of resource use, inter-industry linkages, forms of organization), the technologies, quantities and qualities of consumption, patterns of labor demand and supply and of physical and social infrastructures" (Harvey, 1985). As a basic premise, movement over space can be attained only by fixing certain physical infrastructures into the built environment (Harvey, 2003). Railways, roads, port facilities, water and sewage systems, etc., represent fixed capital rooted in the landscape. Such physical 
infrastructures absorb much capital, which can only be recovered if the structures are used in situ. As a result, fixed capital invested in the land assists in the spatial mobility for other forms of capital and labor, this, in order for its value to be realized, must follow a fixed geographical pattern. Because of the fixity of the physical infrastructure, the key contradiction of fixed capital emerges as it hinders geographical transformations and relocation of capitalist activity (Harvey, 2003).

The formation of physical and social infrastructures not only support economic activity they also circulate cultural and educational values and strengthen the coherence of a region within the national or global economy (Harvey, 2003). Patterns of trade, industry or technologies link regional economies into a pattern of uneven geographical development. However, at the same time, there are processes at work that undermine this coherence. First, accumulation and expansion, in addition to the need to produce and absorb labor power and capital surpluses, increase pressures within a region that spill outwards (capital export) or pull inward (immigration) (Harvey, 1985). Second, revolutions in technology and transportation free production and consumption from their spatial constraints and improve the ability to overcome spatial barriers. Third, class struggle within a territory may force capitalist and / or laborers to move in order to find conditions that are more tailored to their realization of profit. Fourth, revolutions in capitalist forms of organization, which follow advancements in technology and transportation, allow capitalist to expand over larger areas (Harvey, 1985). 


\section{Time Space Compression}

Harvey (1990) states that the capacity to measure time has been revolutionized, first through the production and diffusion of accurate time keeping devices as well as by the speed and coordinating machinery of production (automation, robotization) and the speed of movement of goods, people, information etc. (Harvey, 1990). As a result, the material foundation of space and time has become moving rather than fixed datum points in the landscape. Time is vital under capitalism because labor time is the measure of value and surplus labor time lies at the origin of profit. In addition, the turnover time of capital is significant because an increase in production and capital is a powerful competitive advantage for individual capitalists to exploit. In times of economic crisis and intense competition, capitalists with faster turnover times are able to compete more efficiently than others who cannot. The result of faster turnover times is that intensity of working and living tends to increase, and the rate of change accelerates. The elimination of spatial barriers and the effort to "annihilate space by time" becomes heightened in crises of capital over-accumulation and is essential to the whole dynamic of capital accumulation (Harvey, 1990).

On the other hand, accumulation for accumulations sake produces continuous revolutions in transportation technology as well as a continuous push to overcome spatial barriers - all of which are disruptive to any existing spatial pattern (Harvey, 2002a). Hence, a contradiction arises that in order to overcome spatial barriers and to annihilate space with time, spatial structures are created which act as barriers to further accumulation. These spatial structures are articulated in the form of immobile transport facilities and associated works built in the landscape. These long term, high cost 
facilities of fixed capital investments of slow turnover time are needed in order to speed up the turnover time of the rest, and it takes the production of a specific set of space relations (like a rail network or highway system) in order to annihilate space by time. As a result, revolutions in temporal and spatial relations often follow, destroying not only ways of life and social practices built around preceding time - space systems, but also a wide range of physical assets embedded in the landscape. The geographical landscape which results is one that best fits the present capitalist development. At the same time however, it expresses the power of past labor over present labor as it inhibits the accumulation process within a specific set of spatial physical constraints. These physical constraints can only be removed slowly unless there is a substantial devaluation of the exchange value locked up in those physical assets. Under capitalism there is a continuous struggle in which capital builds a physical landscape appropriate to a particular moment in time, only to have to destroy it, usually in the course of a crisis, at a subsequent point in time (Harvey, 2002a).

\section{Urban Form}

During the economic crisis of the 1970s a combination of plant shutdowns, movement of production overseas, advancements in technology and transportation have resulted in a transition from a Fordist based social economic organization grounded on a standardized mass production system to one dependant on an economic organization of flexible accumulation. It is this transformation that will be examined in the context of the City of Erie. 
Transition from traditional Fordist mode of production to a regime of flexible accumulation provides one explanation of changes of the built environment associated with the City of Erie under a capitalist framework. Fordism is a historically specific expression between processes of production and mode of consumption (Schoenberger, 1988). The labor process under Fordism is structured on a standardized mass-production operation based on costly fixed purpose machinery. However, a fundamental contradiction arises, as mass production must be offset by its counterpart mass consumption in order to absorb the output of the production system. The possibility for mass consumption arises from a transformation of the conditions of the working class, especially through the institutionalization of the capital-labor relation in collective bargaining. Labor tranquility is traded for wage increases in line with productivity growth (Schoenberger, 1988).

An inherent weakness in the Fordist regime of accumulation is it can only be maintained as long as it is confined to a few core countries (Schoenberger, 1988). Fordism depends on and ability to control product competition and prices. Competition is therefore channeled into product differentiation, advertising, and distribution. Global expansion of Fordism has disrupted price and product stability. The production techniques associated with Fordism, combined with an inability of the domestic market to absorb the output of production, channels investment abroad bringing an end to traditional relationships of production and consumption which throws the entire system into disarray. Firms within the core countries find themselves at a serious competitive disadvantage with competing firms that have not adopted traditional controls of products, prices, and wages (Schoenberger, 1988). 
Pressures of increasing international competition have forced capital to 1) find cheap compliant sources of labor in less developed countries in order to regain competitive advantage (Schoenberger, 1988). This diffusion of firms from the core to the periphery has been made possible by advancements in transportation and technology to effectively annihilate space by time. 2) Adopt a flexible mode of production. Flexible forms of production differ from traditional modes in that a given machine can be programmed to manufacture a range of products and configurations in contrast to fixed purpose dedicated machinery (Schoenberger, 1988). Flexible forms of production free traditional forms of mass consumption form the constraints of Fordist style mass production.

As a result of a globalized economy, export of domestic firms and the influx of foreign competitors in the 1970 s and 80 s there has been massive exportation of businesses and people in several mid-western cities such as Cleveland, St. Louis, Indianapolis, Pittsburgh and Erie. As a result, these cities began to engage in growth coalitions that began to reinvent themselves and their cities and offset economic and physical decline with new possibilities for urban growth (Wilson and Wouters, 2003). As a result, cities had to become entrepreneurial if globalization could be turned to their advantage. The discourse pushed for one kind of growth, which emphasized the establishment of upper-class neighborhoods, high technology growth nodes, elite cultural districts and consumption retail zones. One of the most consistent themes in the discourse was the idea of accelerated competition between cities for investment and jobs. Due to increased globalization and the erosion of barriers to the movement of capital and 
equipment, cities were forced to create a business climate that was favorable to promoting investment (Wilson and Wouters, 2003).

As a result of the transition from a Fordist production system to a distinctly PostFordist style of production, there has been a shift form a managerial to an entrepreneurial style of urban governance. Harvey (2002b), states that the 'managerial' approach typical of the 1960s steadily gave way to 'entrepreneurial' forms of action in the 1970s and 1980s. The recession of the early 1970s resulted in widespread de-industrialization, 'structural' unemployment, fiscal rigidness at both the national and local levels, as well as a stronger demand for privatization (Harvey, 2002b).

Harvey (2002b) offers three affects that entrepreneurialism has had on typical American cities. First, entrepreneurialism represents the idea of a "public-private partnership" in which a traditional local interest is integrated with local governmental powers to try and draw in external sources of funding, investments, or new employment opportunities (Harvey, 2002b). Secondly, the activity of the public-private partnership is entrepreneurial in nature because it is speculative in execution and design. Therefore, it is affected by the difficulties that are associated with speculative as opposed to rationally planned and coordinated development. Thirdly, entrepreneurialism focuses more closely on the political economy of a place rather than of territory. The construction of place (a new civic center, an industrial park) or the enhancement of conditions within a place (intervention in local labor markets) can have impacts on than a territory where such projects are located (Harvey, 2002b).

The result of these affects, is that entrepreneurialism implies some level of interurban competition (Harvey, 2002). As inter-urban competition becomes more focused, it 
functions as an "external coercive power" over individual cities to bring them closer into line with the discipline of capitalist development. As a result, cities stand to improve or lose their economic strength if they do not offer enterprises necessary conditions to come to or remain in town. The reduction of spatial barriers has made competition between localities for development capital even more heightened. Urban governance has become more focused on the creation of a "good business climate" in an effort to attract highly mobile and flexible production, financial, and consumption flows into its space (Harvey, 2002b).

As a consequence to the changes in the structure of production and the advent of globalization, capitalism has moved into a phase in which the cultural forms and meanings of its outputs became critical elements of productive strategy (Scott, 1997). In some cases, they come from traditional manufacturing sectors engaged in production (e.g. clothing, furniture). Other cases take the form of services that involve personalized production and diffusion of information (e.g. tourist services). These individual identities are developed as tourist destinations with complex interlocking of production and service functions that lure consumers on the basis of a unique asset (physical or cultural) that is then made accessible and continually re-imaged as the local production system (Scott, 1997).

\section{Socio-Spatial Practices and the Historic Construction of Place}

Two theoretical interpretations of space and place provided by Massey and Harvey will be used to understand not only the social construction of space and place, but also to examine their effect on the local. Although Harvey and Massey share broad 
similarities in their conceptualizations of space, the conclusions that they draw are vastly different. Massey (1993) disagrees with those who interpret the current phase of timespace compression (accessibility and distanciation) as primarily generating insecurity in spatial relations and argue that 'place' is a source of stability and an un-problematical identity. In other words, a sense of place is constructed out of an introverted, inward looking history based on exploring into the past for internalized origins. For Massey, capitalism and its developments are insufficient in the explanation of our understanding and experience of place. What gives a place its specificity is not some long internalized history, but the fact that it is constructed out of a particular constellation of relations brought together at a particular locus. Instead of thinking of places with boundaries, they can be expressed as fluid movements in networks of social relations and understanding. This conceptualization allows for a sense of place which is extroverted, includes a awareness of its links with the wider world and integrates in a positive way the global and the local (Massey, 1993).

While Massey's interpretation draws heavily on social relations as the root of understanding space and place, Harvey conceptualizes space and place hand in hand within a more critical perspective of globalized capitalism. Harvey (1990) states that the more global inter-relations between place and space become and the more spatial barriers disintegrate, the more the world's population adheres to place, or nation, as specific marks of identity (Harvey, 1990). In other words, the reduction of spatial barriers under global capital has brought about an increasing sense of nationalism and localism. Due to the reduction in the power of spatial barriers, geo-political rivalries and tensions arise from an inability to separate and defend against others. The capitalist response has been 
to re-invent tradition as yet another item of commodity production and consumption (i.e. the re-enactment of local traditions and spectacles and a renewed interest in local heritage and culture). The reduction of spatial barriers has also made competition between localities for developmental capital even more acute. The task of local urban governance has become to entice highly mobile and flexible production, financial, and consumption flows into its space and become much more oriented to the creation of a "good business climate" in order to attract capital (Harvey, 1990).

Both of the conclusions drawn from Massey and Harvey lay a solid foundation for understanding the complexities of space and place. However, a third, physical aspect is also an integral part in our conceptualization. Investigating spatial outcomes needs to be addressed through an understanding of the contingency of natural processes on social process. In order to more completely appreciate what constitutes place, an understanding of flows of physical activity needs to be investigated. In the case of Erie, physical activity and events play an important role in the complexity of space. Processes such as lake level, erosion, deposition, bluff recession, wave activity, wind, precipitation and ice build-up, all have profound effects on the space and place.

In conclusion, integrating physical forces with the two conceptualizations provided by Massey and Harvey illustrates the interdependence between social and physical processes. The interplay between these two forces is sometimes complementary and at other times contradictory. The presence of the peninsula played a complementary role in the City of Erie's ability to adapt to changes in economic structure over time. With respect to recreation, Presque Isle and its uniqueness as a natural feature in the region has the ability to attract capital under a regime of flexible accumulation. Because 
the peninsula is a dynamic and evolving landform, natural forces tend to be contradictory to the social forces attempting to exploit its presence. From the first engineering efforts constructed to combat erosive forces in 1829 to present day sand replenishment and "natural" aesthetic erosion control measures, social forces have been at work in an attempt to maintain and protect the peninsula from the dynamic physical forces that threaten its stability.

\section{Social Production of Nature}

Contemporary geographic literature has treated issues concerned with the society - nature interface from three theoretical approaches external, intrinsic and universal (Castree, 2001). External refers to a distinction between society and nature that indicates nature is external and explicitly non-social or nonhuman. Intrinsic nature conceptualizes nature as an essential and unchanging quality of something (i.e. external nature and / or human nature). Thirdly, universal nature, contradictory to external nature has two aspects; first is to identify natural characteristics generally rather than specifically. Second, nature is seen as encompassing everything biological including human beings (Castree, 2001).

Historically, the three above definitions that geographers have applied to nature infer that 1) nature operates through a set of truths based on how natural systems operate (Castree, 2001). This argument is used to illustrate facts about disappearing environments. 2) Definitions of nature offer society a set of resources that are essentially unchangeable. Often this definition is used to call for a restriction of human activities in order to preserve rapidly vanishing first nature. 3) Definitions of nature are used to 
determine value judgments on what is viewed as good / bad, normal / abnormal either socially or ecologically. For example, preservation of natural resources is often seen as an innately valuable, whereas use of those resources is intrinsically negative as they disrupt the inherent balance of nature (Castree, 2001).

The view of nature this research employs differs from the above theoretical position in that nature is placed in an historical context, demonstrating the development of the material landscape as an increasing process of a social production of nature (Smith, 1984). Through progress in capital and the expansion of the economy, the material landscape has been altered and transformed from its initial pristine state (first nature) to one that reflects more and more a product of social production (second nature). In short, second nature and the social production of nature under capitalism reflects the way in which human activity has transformed the earth's surface through human labor, as well as, the legal, economic and political rules by which society operates (Smith, 1984).

It is from this conceptualization of nature that allows the research to exclude the above universal, intrinsic and external conceptions of nature as it shows the inaccuracy of perceiving nature as pristine, untouched by human activity. Instead, the research points to an internal conception of nature, one that is unavoidably social. From an internal standpoint, nature is defined and physically constructed by different societies in order to serve dominant social interests (Castree, 1995). Secondly, it allows for an understanding of how capitalism commodifies landscapes and constructs and reconstructs those landscapes in particular profit motivated ways. Third, it unveils particular networks of exploitation of natural products in specific places. Fourth, it historicizes social relations 
with nature which, in turn, allow for unique possibilities of investigation concerning the interconnectivity of politics and the transformation of nature and society (Castree, 1995).

In short, Castree (1995) views the production of nature as capturing:

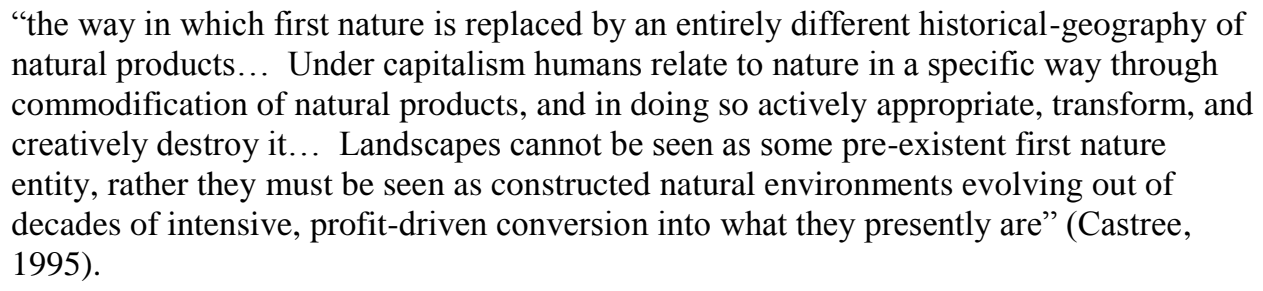

This chapter has been designed to develop an understanding into the development and evolution of place. Conceptualizations on the effects of capitalism with concern to place, from a historical perspective, provides meaning on how the capitalist system has grounded itself at a particular location, and identifies conditions that exist which undermine capital fixity in the landscape. Furthermore, socio-spatial practices with concern to historic production of space have been placed within a historic perception / social production of nature framework in order to provide knowledge into social factors contributing to the construction of place. From this point forward in the research, conceptualizations concerning natural and social processes involved in the production of place will be examined within the context of the City of Erie and Presque Isle. Tying the above conceptions with the case study of Erie and Presque Isle has been designed to illustrate how the space of the capitalist system derives its meaning through place. 


\section{Chapter 4: Industrial Era City of Erie / Engineering History}

The purpose of this chapter is to provide a case study for the conceptualizations expressed in the previous chapters of this research. This chapter is designed to illustrate changes associated with the City of Erie and Presque Isle which tie physical process with social processes with concern to a more holistic understanding of the nature of place. A theoretically informative narrative has been constructed designed to uncover the relationship between a dynamic physical landform of Presque Isle with changing economic structure found within historic context of the City of Erie. The goal of this chapter is to express the interdependence between industrial activities associated with the City of Erie and the historic role the peninsula has played with regard to the production and maintenance of economic exchanges from Erie's incorporation in 1796 through the mid-20 $20^{\text {th }}$ Century.

\section{Presque Isle}

Development and sustained existence of industry in Erie is closely linked to Presque Isle peninsula. The natural harbor created by Presque Isle has been associated with commerce since the initial settlement at Presque Isle in 1795. Efforts to stabilize the inherently unstable landform of the Presque Isle shoreline began soon after commercial exploitation of the harbor.

The peninsula is a geomorphic feature formed during the North American Pleistocene glaciation period (Figure 1) (Mohr et al, 1999). The peninsula is a compound, re-curved sand spit that arches southward approximately $4 \mathrm{~km}(2.5 \mathrm{mi})$ from 
the southern shore of Lake Erie (Gorecki and Pope, 1993). The length of the peninsula from its eastern connection to the mainland to its western terminus is approximately 10 km (6.25 mi) (Mohr et al, 1999). The neck of the peninsula (Figure 1), which extends from the mainland approximately $3.2 \mathrm{~km}(2 \mathrm{mi})$ has an average width of less than $244 \mathrm{~m}$ $(800 \mathrm{ft})$. East of the neck, the peninsula widens to an approximate width of over $1.6 \mathrm{~km}$ (1 mi). The eastern terminus, Gull Point (Figure 1), is an accretionary feature which terminates in several low, flat, re-curving longshore bars (Mohr et al, 1999). The peninsula consists mainly of fine sand, from up-drift bluffs, reworked by wave action originating from glacial deposits. From 1824, the initial appropriation of funds to provide a deep entrance to the harbor, to present, an array of engineering efforts have been made designed to retard erosive forces at work on the peninsula including; tree plantings, groins, traps, bulkheads, and most recently, sand replenishment and offshore breakwaters.

\section{Early Industries and Presque Isle}

Industry early in Erie's history was limited to shipbuilding and the transportation of salt from the deposits found to the east of Erie (Schaney, 2003). The salt industry was of particular importance as it established Erie as an early center of inland commerce (Erie County Unit of the Federal Writers' Project of the Works Progress Administration for the Commonwealth of Pennsylvania (FWPCOP), 1938). During this period in Erie history, the peninsula acted as a barrier to continued economic growth due to the shallow natural entrance to the bay (Figure 4). Due to this natural barrier to commerce, cargos of salt were unloaded to the east of the peninsula entrance (Schaney, 2003). 


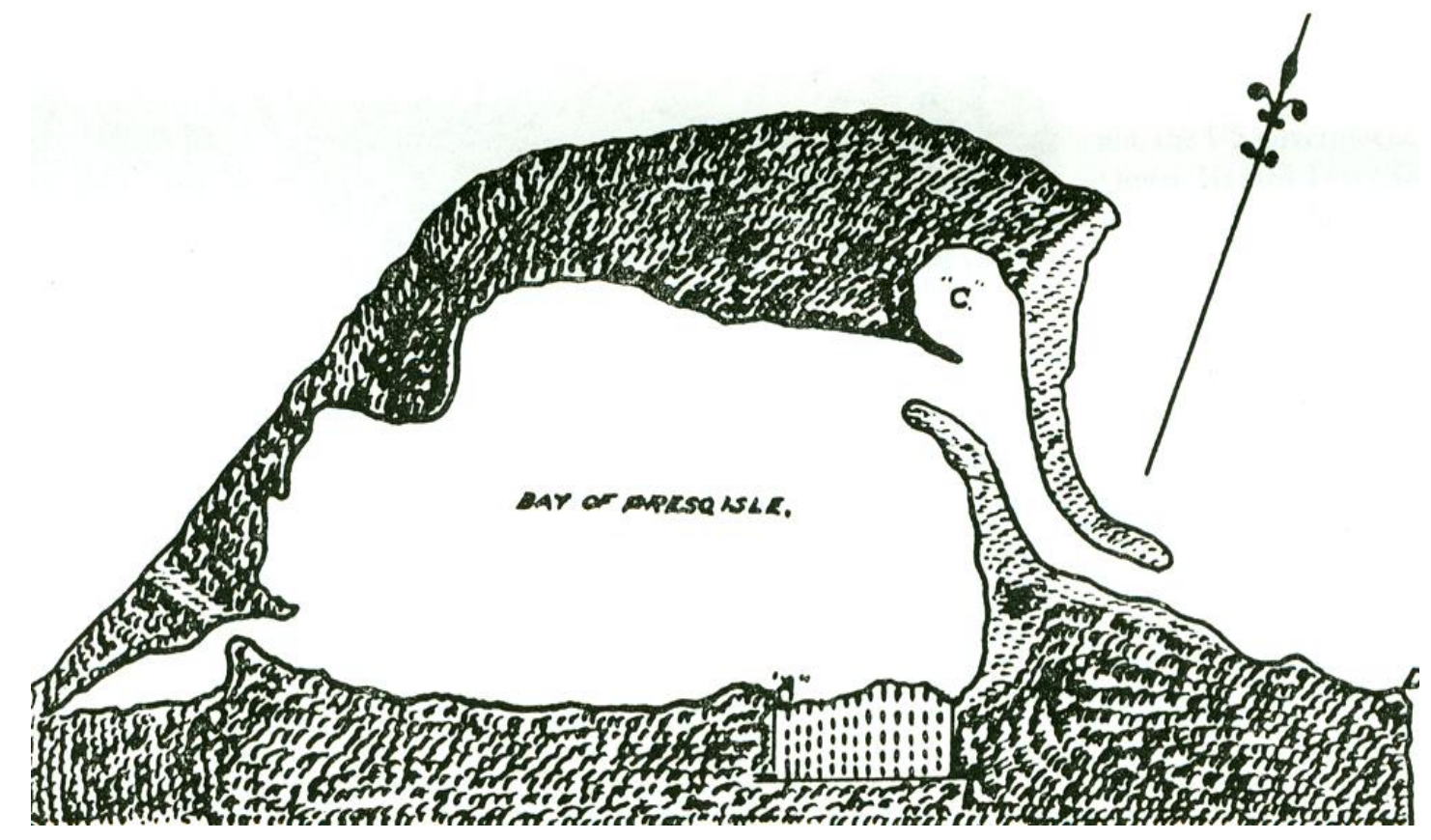

Figure 4: Historic map illustrating the natural entrance to Presque Isle (no scale or original date of publication given) (Swisher, 1979) (Schaney, 2003). 


\section{Harbor Improvements}

The shallow entrance to the bay became an increasing impediment to continued commerce. Advancements in shipping technology led by the development of large deep draft steamships became more common on the Great Lakes (Schaney, 2003).

In order to promote continued economic exchange and take advantage of increasing shipping opportunities on the Great Lakes, plans were developed to deepen the harbor entrance. By 1827 a deep entrance channel was dredged, and construction of a series dikes and piers was completed (Schaney, 2003) (Figure 5).

Improvements to the harbor offer the first evidence of the competitive nature of the natural forces at work on the peninsula and contradictory social forces attempting to exploit its presence. Initially, industry located within the Erie region (shipbuilding and salt industry) was able to function despite the natural first nature condition of the peninsula. However, revolutions in transportation as evidenced by the arrival of deep draft steamships and their increased capacity for cargo, initiated modification of the natural state of the peninsula. This initial modification of the peninsula, put into motion by revolutions in shipping technology, began the transformation of Presque Isle from its original unaltered natural state into a second nature cultural landscape. Once modification of the harbor entrance had taken place, it facilitated continued engineering practices designed to retard dynamic geomorphic forces threatening the stability of the land form and closely associated economic exploitation. 


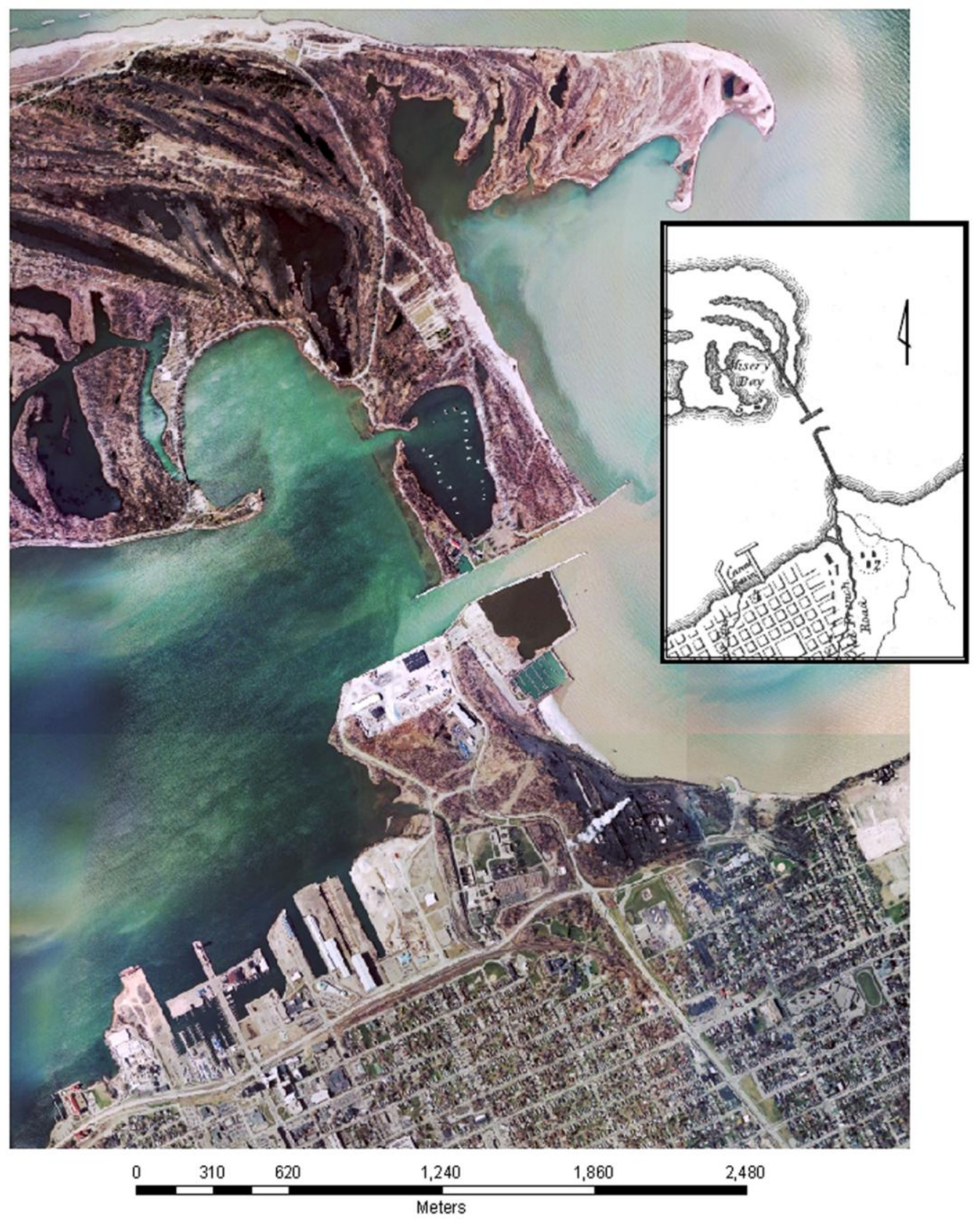

Figure 5: Entrance to the harbor as illustrated in a PA Map image acquired 2005 (www.pasda.psu.edu). Inset is an artist rendering of the harbor entrance 1836 (Swisher, 1979). 


\section{Mid-19 ${ }^{\text {th }}$ to Mid-20 ${ }^{\text {th }}$ Century Developments in Transportation}

By the Mid-19 ${ }^{\text {th }}$ Century, the harbor associated with the peninsula began to develop around the shipping industry associated with the Great Lakes. Harbor improvements such as storage and stevedoring facilities were constructed, promoting and attracting increased shipping activity (Schaney, 2003). Increases in shipping activity were driven by the completion of the Erie Canal in 1825 which linked Lake Erie and the Great Lakes with the Hudson River and the east coast port city of New York (Birdsall et al, 2009). The connection to the east coast was paramount to the development of Great Lakes ports as it was the first time in United States history the barrier of the Appalachian Mountains was eliminated in an effort to annihilate space by time. Additionally, a second canal, the Erie Extension Canal completed in 1844, directly connected Erie with Pittsburgh and coal fields of central Pennsylvania and West Virginia (Schaney, 2003). Completion of the Erie Extension Canal connected Presque Isle harbor to Pittsburgh coal creating an important link for Lake Erie shipping (Schaney, 2003).

However, early connections to the east coast afforded by the construction of the canals were quickly undermined by continued efforts to increase turnover time of capital. By the early 1860s, railroads had established a connection which linked Erie to the eastern seaboard (Schaney, 2003). By 1871, increased railroad competition and difficult maintenance initiated the abandonment of the canal system. Once abandoned, the railroads absorbed the devalued former canal right of way and harbor facilities associated with Presque Isle which in turn, increased all aspects of shipping and storage facilities associated with the harbor (Schaney, 2003). 
Advancements in overland transportation connections from the Great Lakes to the east coast exemplify contradictions that arise in order to overcome spatial barriers and annihilate space with time. With respect to the canal system, long term, high cost spatial structures of fixed capital investments and the production of a specific set of space relations has acted as a barrier to further capitalist accumulation (Harvey, 1990). As a result, revolutions in temporal and spatial relations, the development of the railroad, effectively destroyed social practices, ways of life and a wide range of physical assets embedded in the landscape built around preceding time - space systems (Harvey, 2002a). Once railroad connections were established to the harbor, overland revolutions in transportation were limited to advancements in railroad technology (iron to steel rail, standardization of rail gauges and steam to diesel engines). Overland transportation routes, with respect to harbor connections, would not be seriously challenged until the mid- $20^{\text {th }}$ Century by developments in the St. Lawrence Seaway, highway development and airplane freight services.

By the mid- $19^{\text {th }}$ Century, continued advancements in shipping technology began to emerge on the Great Lakes. The first iron vessel on the lakes was the USS Michigan built in Erie (Whitlark, 1959). By 1882, the prototype to modern bulk freighters, the vessel Onoko, was built in Cleveland, Ohio. The Pittsburgh Steamship Company built the first steel $150 \mathrm{~m}(500 \mathrm{ft})$ bulk freighter in 1900. Standard $180 \mathrm{~m}(600 \mathrm{ft})$ Great Lake bulk freighters appeared in 1906. Presently, $200 \mathrm{~m}(700 \mathrm{ft})$ bulk freighters regularly travel throughout the Great Lakes system (Whitlark, 1959).

In many cases, rapid revolutions in transportation and technology have had the contradictory effect of destroying ways of life and social practices built around preceding 
time - space systems, as well as a wide range of physical assets embedded in the

landscape. In the case of rapid revolutions in transportation technology from canal to rail from a landward perspective and sailing vessels to stream ships and bulk freighters from a maritime perception, the City of Erie and the presence of the Presque Isle has provided industry with a "natural" competitive edge. This advantage has enabled the local economy to overcome economic crisis and transition on multiple aspects of industry and reproduce structured coherence in the wake of advancements in technology and transportation that would otherwise undermine that advantage.

\section{Presque Isle Migration and Early Breaches in the Neck}

Although the development of a deep entrance to the harbor was undertaken to stimulate economic exchange and continued growth of Erie's shipping related economy, Geomorphic forces behind eastward migration of the landform, and the closely related forces behind early breaches in the neck provide the first evidence in the transformation of Presque Isle from its initial pristine state, to one that reflects more and more a product of social production (Smith, 1984). It is during this early period in Erie history that provides an illustration into the beginnings of how the production of nature not only serves dominant social interests, but how capitalism has commodified, constructed and reconstructs the peninsula landform in particular profit motivated ways (Castree, 1995).

Even though the improved harbor entrance increased shipping and storage capacity, engineering efforts to stabilize dynamic geomorphic forces influencing the Presque Isle shoreline would continue. A combination of longshore drift, lake level and erosion and re-deposition has resulted in the eastward migration of the peninsula (Figures 
6 and 7) (Schaney, 2003). This migration would continue today unchecked, were it not for the stabilization activities being carried out on the peninsula by Pennsylvania and the USACE. Eastward migration of the peninsula combined with historic breaches in the neck, are directly responsible for continued engineering efforts by the USACE to maintain an effective platform for further capitalist accumulation.

In addition to eastward migration, breaches in the neck have continually affected the stability of the landform. Breaches in the neck of the peninsula were viewed as detrimental to the continued economic vitality of the economy associated with the City of Erie and Presque Isle. Additionally, breaches were perceived as potentially destroying the natural competitive advantage that has allowed the city of Erie to absorb revolutions in transportation and efforts by capitalists to annihilate space by time. As a result, aggressive action had been taken to close historic breaches, as illustrated below, and have continued to play an important role in present day engineering activities associated with the peninsula.

Historically, breaches have been associated with seasonally high lake levels, which coincide with early winter storms, and high energy destructive waves (Schaney, 2003). The neck of Presque Isle is most vulnerable to breach during the limited period in November, April and May when strong seasonal storms and ice-free conditions occur simultaneously (Thomas et al, 1987).

During the winter of 1828-29 (no specific date found), the first recorded breach of the peninsula neck occurred (Schaney, 2003). Once filled, this breach provided 


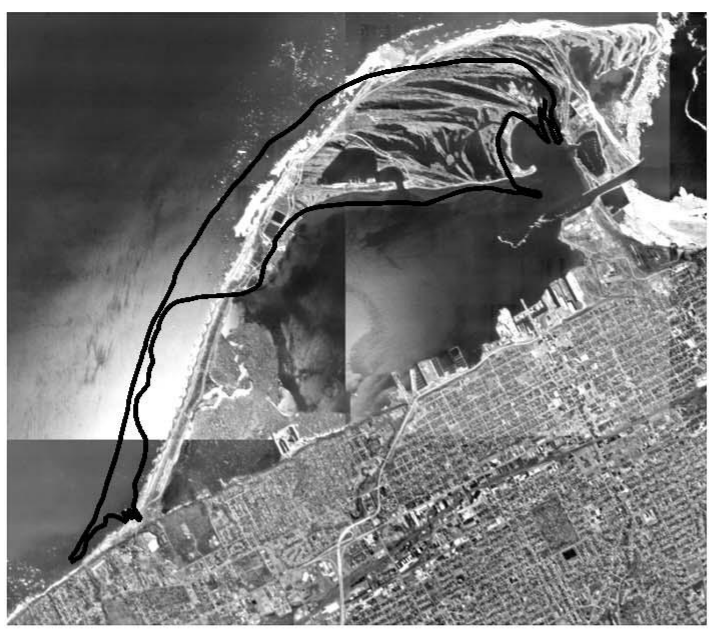

1819

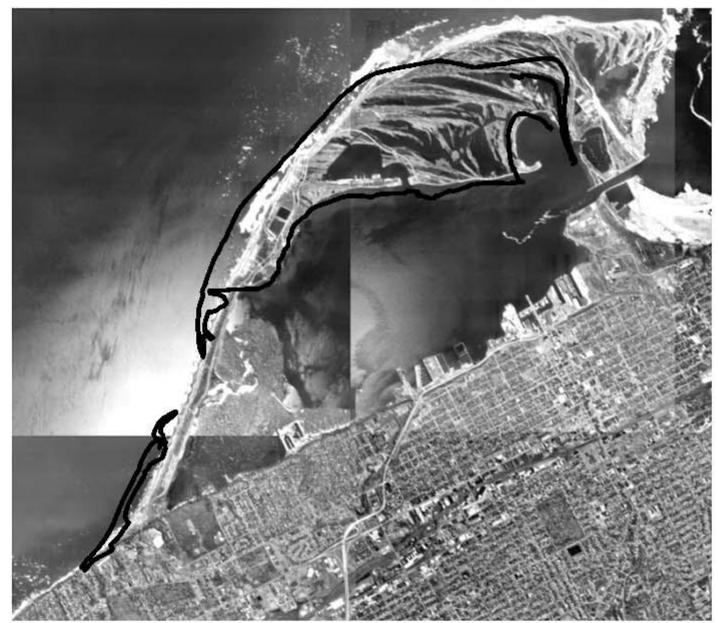

1839
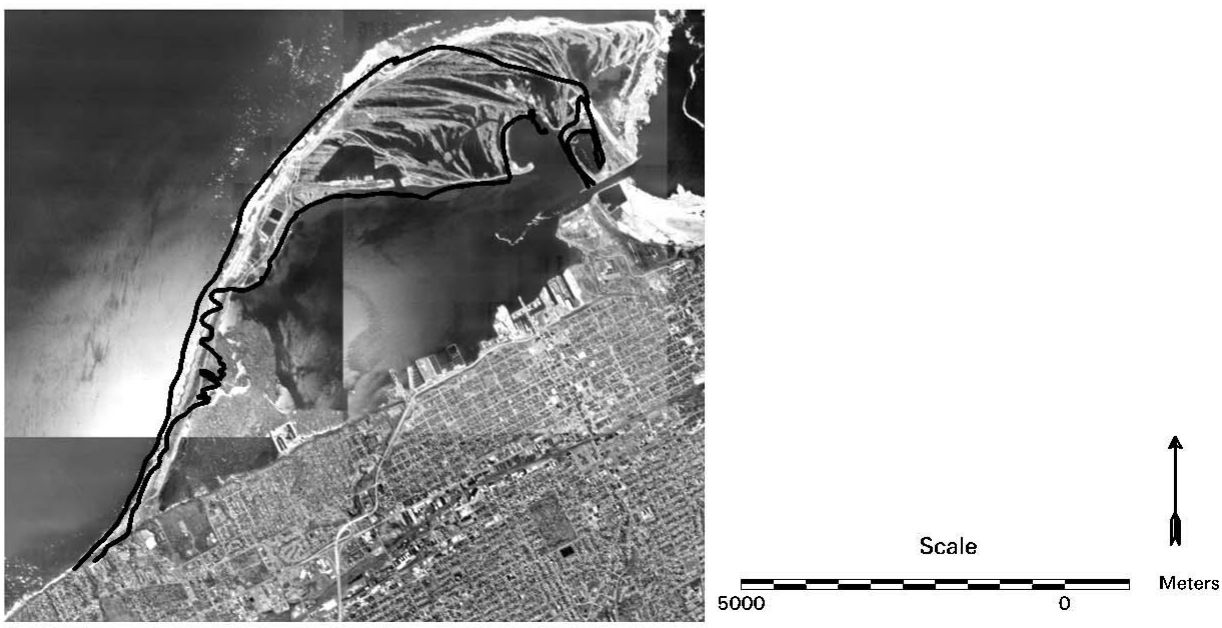

1865

Figure 6: Digitized shorelines of 1819, 1839 and 1865 overlaid on a 2002 aerial photography mosaic documenting the eastward migration of Presque Isle (Schaney, 2003). 

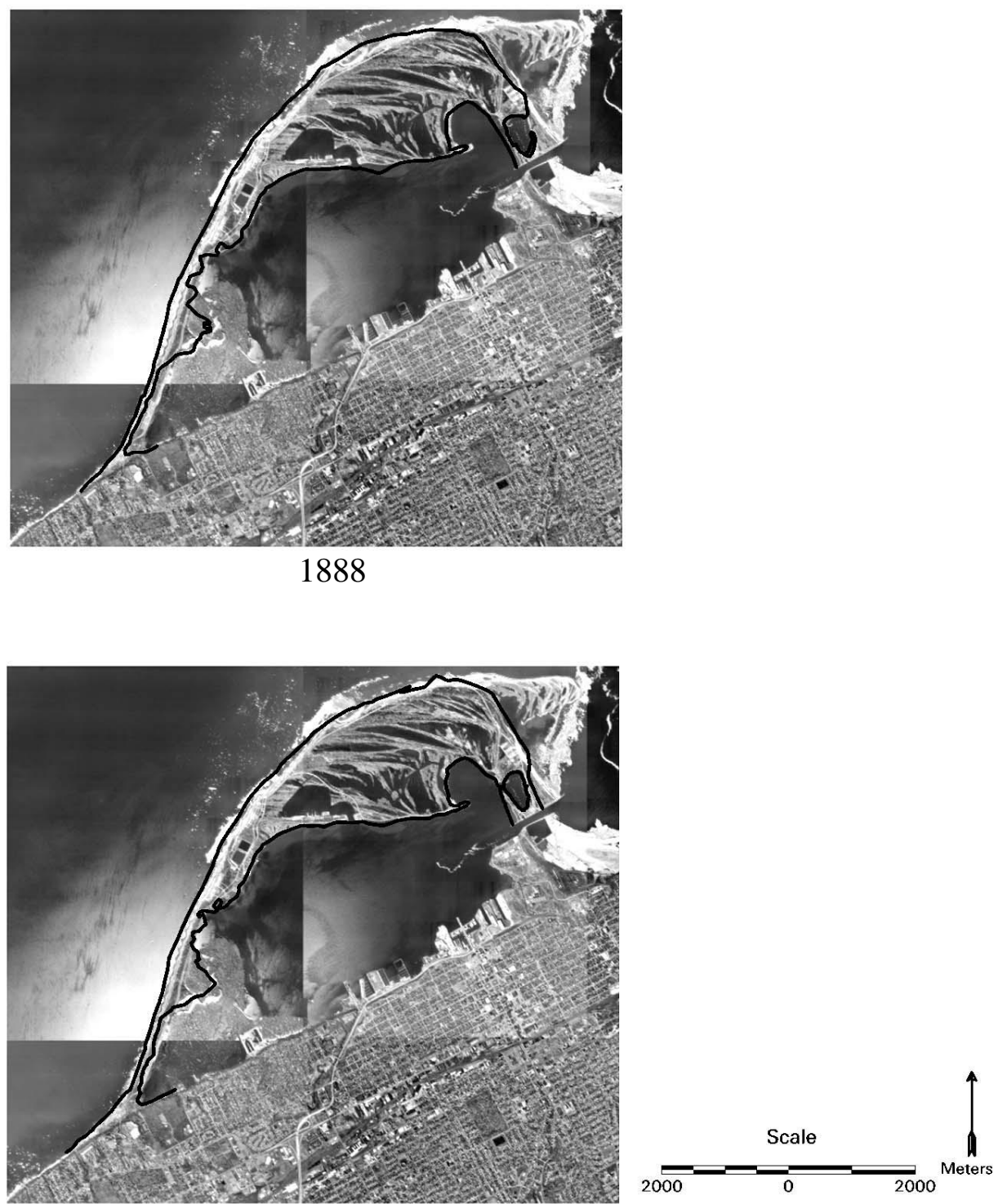

1907

Figure 7: Digitized shorelines of 1888 and 1907 overlaid on a 2002 aerial photography mosaic documenting the eastward migration of Presque Isle (Schaney, 2003). 
the initial impetus for USACE to maintain the peninsula shoreline and the connection to the mainland (Schaney, 2003).

Despite earlier engineering efforts, storms during the winter of 1832-33 (no specific date found) caused a second breach in the peninsula neck (Figure 8). Between 1835 and 1857 several engineering techniques were used in an attempted to close the breach (Schaney, 2003). By 1864, despite several engineering efforts, the breach was reportedly closed by natural long shore depositional processes (Schaney, 2003).

\section{Mid-19th - Early 20th Century Industry}

As engineering activities by the USACE continued in an effort to transform Presque Isle into an effective economic platform, advancements in industrial and manufacturing capacity of the northeastern United States continued to increase. Erie's position on the Great Lakes allowed for continued utilization of the harbor as an important transportation hub for the distribution of freight and natural resources used in manufacture. As a result, during this time period Erie began to establish itself as an important manufacturing / industrial location.

As work on stabilizing and maintaining Presque Isle continued, an iron foundry established in 1833 by Hinkleym Harvis and Company was the initial industry that launched Erie as a center of industrial importance (FWPCOP, 1938). The foundry smelted iron which, from Erie, was transported south to Pittsburgh (FWPCOP, 1938).

As iron industries gained prominence within the harbor, continued success of the railroads contributed to the growth of shipping in Erie. By the 1880s, three bulk shipping companies operated out of Erie dominated by iron ore, coal, grain, limestone, salt, paper 


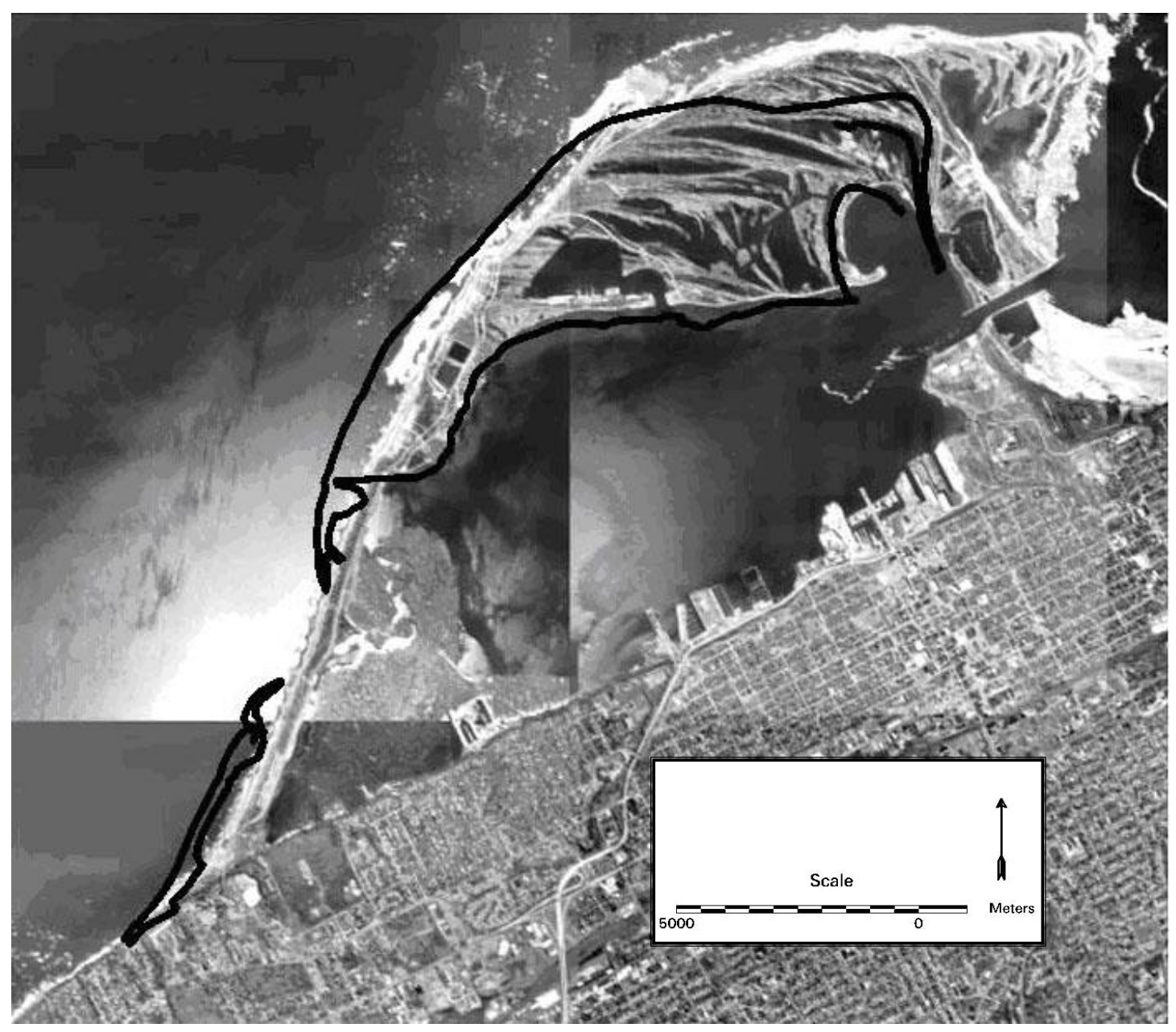

Figure 8: Digitized 1839 shoreline overlaid on a 2002 aerial photography mosaic illustrating second breach in the neck of the peninsula (Schaney, 2003). 
and wood (MacDonald and Frew, 1996). The expansion of the shipping industry through Erie continued to expand the harbor facilities associated with the harbor (Schaney, 2003).

By the beginning of the $20^{\text {th }}$ Century, several small local Erie shipping companies had become established within the harbor. However, the depression associated with the 1930s, had resulted in the demise of local Erie shipping companies (Schaney, 2003). The effect of the depression on the local shipping industry marked a general transition to large regional specialized bulk shipping (Schaney, 2003).

\section{Continued Breaches on Presque Isle}

As the harbor facilities were being expanded during the mid- $19^{\text {th }}$ Century to accommodate growth in commodities and industry utilizing the harbor, the peninsula neck was breached for the third time in November of 1874 which was closed in 1875 (Schaney, 2003). Maintenance of the peninsula required continual work because the construction materials and techniques used to stabilize the peninsula were not able to withstand the severe winter storms. By 1880 groins were used on the peninsula for the first time in an effort to stabilize westward migration and maintain shoreline integrity (Schaney, 2003).

In October1917, a severe storm created the fourth and final breach, which was closed in 1922 (Schaney, 2003). Also in 1922, Presque Isle was turned into a Pennsylvania State Park. 


\section{Mid-20 ${ }^{\text {th }}$ Century Developments in Transportation}

Throughout the early period of Erie's history, the advantage provided by presence of Presque Isle on the Great Lakes enabled the City of Erie to connect with larger regional economic patterns of resource use, networks of labor demand and supply, interindustry linkages and physical and social infrastructures through the peninsula. As a result, the presence of the peninsula and its harbor allowed for the reproduction of structured coherence in wake of advancements in transportation technology. However, during the mid-20 ${ }^{\text {th }}$ Century, continued advancements in transportation technology driven by continued efforts to reduce the cost of movement over the landscape began to erode traditional industry / market networks and advantages afforded by Presque Isle.

Until the 1930s most of the shipping on the Great Lakes was internal packaged freight and bulk trade carried by inland fleets of Canada and the United States (Whitlark, 1959). However, the effects of the depression of the 1930s initiated restructured shipping traffic from a closed Great Lakes system to one that incorporated international bulk shipping. By the 1950s the United States in a partnership with Canada agreed to build the St. Lawrence Seaway (Seaway), which would link the Great Lakes with the Atlantic Ocean through the Welland Canal and the St. Lawrence River. Opening of the Seaway would allow ocean freighters into the Great Lakes, greatly increasing the variety and quantity of bulk commerce. It was thought that the construction of the Seaway would benefit all ports on the Great Lakes. Large harbors would have a direct line with international trade and small ports would benefit by regular shipping services (Whitlark, 1959). 
By the mid-20 ${ }^{\text {th }}$ Century, it was clear that shipping would be confined to larger ports along the Great Lakes. Major areas of commerce on the Great Lakes include; iron ore, from the Lake Superior region, shipped to ports in Gary, Indiana and Chicago, Illinois on Lake Michigan and Ashtabula, Cleveland, Conneaut, Lorain, Huron, Ohio, and Buffalo, New York on Lake Erie (Whitlark, 1959). Others include coal, from the coal fields of Pennsylvania, Ohio, Kentucky and West Virginia which is shipped north via railway to Lake Erie ports such as Toledo, Conneaut, Ohio and Buffalo, New York. Limestone from the Lake Huron region traveled to lower lake ports such as Calcite, Alpena, Port Inland, Port Dolomite, Drummond Island. Grain acquired from fields in the mid-west, traveled east through the Seaway to receiving elevators in Buffalo, New York and Toronto, Montreal and Quebec in Canada. Petroleum which is the lesser of the five bulk commodities is mainly centered on refineries associated with Imperial Oil Limited of Sarnia, Ontario (Whitlark, 1959).

In addition to the completion of the Seaway, the region underwent a second major development in transportation with the completion of interstate (I) highways I-79 and I90 through the City of Erie. The first of the two to be completed was I-90. Construction began in 1958 of $74 \mathrm{~km}$ (46 mi) through northwest Pennsylvania from the border of Ohio in the west to the New York border in the east (Amvets, 2006). In October 1960, the entire length of interstate within Pennsylvania was open to local traffic. Construction of the highway was designed to remove the heavy traffic burden from local city streets and to diversify economic and resource opportunities within the City of Erie (Amvets, 2006).

In 1953, the Pennsylvania State Legislature authorized the Pennsylvania Turnpike Commission to construct two north and south spurs of I-79 off of I-76 north of 
Pittsburgh, Pennsylvania (Raymond P. Schafer Highway I-79 2008 (R.P. Schafer, 2008)).

The northern extension was constructed from the Pennsylvania Turnpike north to Erie and the southern section connected I-76 to points south in West Virginia. The final section of I-79 opened in September 1976, creating a continuous interstate from Charleston, West Virginia to Erie (R.P. Schafer, 2008).

In 1982, construction began to extend the terminus in Erie of I-79 into the city center, eliminating a temporary connection to Pittsburgh Avenue (R.P. Schafer, 2008). Construction of the extension to the lakefront known as the Bayfront Parkway opened in October 1990. Construction was designed to spur economic development around the Flagship Niagara, Erie Maritime Museum and Library Complex and the Erie Convention Center located on the harbor (R.P. Schafer, 2008).

\section{End of an Industrial Focus}

Completion of the Seaway in 1959 was initially thought to be the beginning of a major expansion in trade between Europe, Canada, and the central United States (Schaney, 2003). However, intense competition from larger port cities in the Great Lakes system and increased efficiency of large bulk freighters halted the construction of ocean going vessels in the City of Erie (Schaney, 2003).

The second major aspect to the decline of an industrial focus of the harbor was the completion of I - 79 and I - 90. Originally designed to remove the traffic burden from local city streets and to diversify economic and resource opportunities within the City of Erie, the construction of the highway system had the unfavorable result of eliminating regular shipping services furthering the decline of shipping related activity in the harbor. 
As shipping and other industries declined in Erie during the latter half of the $20^{\text {th }}$ Century, Erie industrialists began to utilize the recreational aspects of the peninsula, transitioning economic activity from a focus on industrial activity to one based on a recreational based service economy.

This chapter has been constructed as a narrative to provide historical context of the dynamic relationship between the complementary / contradictory relationship between socio-environmental forces at play within the City of Erie. Geomorphic processes, as well as capitalist developments in transportation and technology have continuously threatened the structured coherence of the region. During the early period of Erie's industrial history, the presence of Presque Isle had enabled the economic base to respond positively to these challenges and reproduce structured coherence through production of the physical, as well as the built environment. However, during the mid $20^{\text {th }}$ Century revolutions in transportation began to undermine locational advantage exemplified by Presque Isle.

\section{Natural Processes and Place}

This chapter has examined the history of Presque Isle and the industrial activities associated with the City of Erie from its incorporation in 1795 through the mid $-20^{\text {th }}$ Century. Overcoming the initial geomorphic challenges of the peninsula, through the construction of a deep entrance to the harbor enabled the City of Erie to fully take advantage of the presence of the peninsula. From that initial Presque Isle development, social / economic forces have used the harbor for competitive advantage. These forces have dictated a static Presque Isle landform found within a dynamic lakeshore 
environment. This dichotomy between a natural and social / economic equilibrium has been responsible for 192 years of engineering attempts designed to neutralize shoreline processes and create a stable environment for industry. The economic advantage the natural harbor provided was soon challenged by continued geomorphic processes at work on the peninsula.

The most detrimental geomorphic affect on the peninsula to a stable social / economic environment were continual breaches in the neck during last two-thirds of the $19^{\text {th }}$ Century and the beginning of the $20^{\text {th }}$ Century. Breaches in the neck of the peninsula have been responsible for the long term stabilization efforts by USACE. Between 1828 and 1917 four breaches occurred along the neck of the peninsula. During those 89 years, the peninsula was disconnected from the mainland for 45 years, approximately 51 per cent of the time. Interesting to note, the second breach from 1832-33 through 1864, closed naturally once lake shore processes reached a state that was conducive to sedimentation, achieving a state of equilibrium.

The instability of the landscape has been continually contradictive to social / economic exploitation. As a direct result, engineering practices employed throughout the industrial era were designed to correct inherent instability and provide a stable platform for continued industrial growth. The engineering practices throughout the duration of Presque Isle's history have been reflective of greater economic forces exhibited within the City of Erie. 


\section{Social Processes and Place}

In addition to the influence of lake shore processes on landscape design, capitalist developments in transportation and technology have had a profound effect on the physical manifestation of structured coherence of the region. These developments are responsible for the creation and continued evolution of the profit driven landscape associated with Presque Isle and the City of Erie.

The economy associated with the city has been able to incorporate changes in transportation and technology throughout the industrial era. From Erie's incorporation in 1795 , shipping and shipbuilding associated with the city has been associated with a widening social / economic region. This widening region was directly influenced by developments in transportation and technology. Erie's first industry, salt, had influence

overland south to Pittsburgh and points along the Ohio River. Throughout the $19^{\text {th }}$ Century, developments in transportation (sailing vessels, steamship, canal, railroad, bulk shipping) continued to widen the social / economic region to include connections to the Atlantic Seaboard, as well as, the Great Lakes system as a whole. This ever widening social / economic net resulted in changes in the City of Erie's landscape with the development and expansion of harbor facilities. The development and expansion of harbor facilities continued until the depression of the 1930s which resulted in a contraction of shipping activities, and a transition from locally owned shipping to nonlocal bulk shipping.

Since the 1930s advancements in shipping technology (super freighters) continued, and were associated with the development of the Seaway and the construction of the interstate highway system. As a result, inter-lake shipping began to be diverted 
towards interstate trucking, and bulk shipping began to be diverted away from smaller ports such as Erie for larger markets associated with Buffalo, Cleveland and Chicago. In the wake of the restructured economic framework associated with shipping, industrial based structured coherence with respect to the City of Erie began to be more heavily reliant on recreation.

\section{Natural / Social Interdependencies and Place}

Due to the presence of Presque Isle, the economic base has been able to respond to challenges brought by advancements in transportation and technology and reproduce the structured coherence of the City of Erie through the production of the physical, as well as, the built environment. Strong evidence of natural / social interdependency has been demonstrated throughout the industrial era and is substantiated by the engineering efforts conducted to create a stable landform. The industrial era, has been defined by continual efforts of the USACE to achieve balance between the natural forces at work on the peninsula, that initially created the harbor environment, with contradictory forces at work on the peninsula, that undermine social exploitation.

Additionally, this chapter has illustrated the slow transformation of Presque Isle from its initial first nature state to one that, through human labor, has been converted into a landform that reflects a product of social production. This conversion to a second nature landscape continues as the economy of Erie transitions from one based on an industrial focus to one that is more heavily involved in a recreation driven service economy. 


\section{Chapter 5: Recreation Era City of Erie / Engineering History}

As alluded to in the previous chapter, Presque Isle has been viewed by the citizenry of Erie as serving the dual purpose of supporting economic exchange and industrial activities for the City, as well as a recreation destination to be enjoyed. Prior to the mid- $20^{\text {th }}$ Century, recreational activities were considered secondary with regard to providing a safe and secure harbor in promotion of economic exchange. This chapter has been designed to illustrate the changing perceptions of the designed use of Presque Isle from one focused on industrious activities to recreation. Recreation era shoreline maintenance and stabilization activities have be examined to illustrate this changing perspective. Furthermore, economic activity during the latter half of the $20^{\text {th }}$ Century has been investigated to illustrate how the produced environment of the peninsula has enabled the City of Erie to transition from an economy based on industrial economic exchanges to a place oriented around recreation driven service.

\section{Recreational Beginnings}

Perceptions of the peninsula, not unlike its economic uses, have changed throughout the history of Erie. Views of nature as held by the citizenry of Erie exemplify the evolution of the conception of an external view of nature. Early in Erie history, the peninsula was viewed from a both perspectives of external nature, which from one perspective viewed the wilderness as the antithesis of civilization, and the other which viewed social infringement on nature as inherently negative. This dual perception of an 
external view of nature held by the citizenry has been demonstrated throughout Erie's history.

Presque Isle has always been viewed from the dual perspectives of either serving economic interests or a unique natural feature to be preserved and enjoyed. By the late 1860s, a disparity in the perception of nature and its intended use began to influence politics and control over the peninsula.

Industrial development of the harbor dominated the landscape by 1913. In response an external, back to nature perspective with concern for a more natural aesthetic began to emerge. For example, John Nolan, a wealthy shipbuilder in Erie, voiced his dissatisfaction with the industrial state of the waterfront associated with the harbor.

\footnotetext{
"Yet at present the arrangement of piers and docks is chaotic and wasteful and such very meager facilities as exist are owned and controlled by the Pennsylvania Railroad system. The whole development is cheap and disorderly and appears to tend to become more so. The city owns none of the waterfront, except the street ends, the water works property and some undeveloped land and water lots at the east end of the harbor. This represents a loss of one of the great natural advantages of the city, which ought to be used to place Erie ahead of cities without a water frontage" (Nolen, 1914).
}

Nolen (1914) envisioned Erie's waterfront with a developed harbor that served a dual purpose which contributed to the success of business and provided pleasure for its citizenry (Schaney, 2003). He proposed to divide the harbor into recreational activity to the west of Erie, and industrial to the east (Schaney, 2003). Nolan's remarks demonstrate a concern that Erie's industrial use of the harbor had reached a state that fell out of harmony with the natural aspects of the peninsula. Nolan suggested the natural aesthetic of the harbor needed to be reemphasized in order to achieve a social / natural balance. 
Early Erie industrialist John Reed viewed the Peninsula from a combined external, nature as the antithesis of civilization / universal, nature viewed as a garden in need of tending perspective. Reed (1925) stated:

\footnotetext{
"Presque Isle peninsula has long been a wilderness into which only the hardy dared venture. It is now being converted into one of the most picturesque parks in the land with ponds, drives, boulevards, and shrubbery in profusion. Here picnickers will delight to come for a summer outing; and here will the tourists and summer visitors delight to ride and stroll by the shores of the lake or along the equally delightful margin of the harbor" (Reed, 1925).
}

Although the view of Presque Isle as a wilderness into which only the hardy dare enter may be a bit extreme, Reed's view of a universal harmony, of a nature that needs to be gardened is clear.

Throughout the $19^{\text {th }}$ and early $20^{\text {th }}$ Centuries, residents of the City of Erie contested the uses of the peninsula from one primarily served the purpose of industry to one that incorporated recreational aspects. Although the industrial focus of the peninsula began to wane in the mid $20^{\text {th }}$ Century, the debate on the dichotomy of external / universal perceptions of nature concerning the peninsula continued.

\section{Creation of a State Park}

In 1922, Presque Isle became a Pennsylvania State Park that was to be controlled by Pennsylvania. By 1930, the Federal Government entered into a partnership with the Pennsylvania that would serve the dual purpose of continuing Federal involvement with regard to protecting the industrial integrity of the harbor through continued shoreline maintenance and stabilization activities, as well as contribute to the recreational appeal afforded by a State Park (Schaney, 2003). The creation of a State Park and the 
dichotomy between protecting industrial integrity while maintaining recreational appeal has been the center of hotly contested debate well into the late $20^{\text {th }}$ Century.

\section{Recreation Era Shoreline Maintenance}

By the mid- $20^{\text {th }}$ Century, the state of the peninsula once again became a subject of debate between universal and external nature perceptions. However, the external position began to move from an obstacle to overcome and conquer in path to progress to a position that expressed a need to return to its natural origins. By 1954, Pennsylvania established a cooperative beach protection program with the Federal Government (Schaney, 2003). This act signified a compromise between the competing viewpoints of the USACE to protecting the peninsula solely for the purpose of maintaining a stable harbor, and the Commonwealth's desire to incorporate a more natural aesthetic for recreational uses.

During the mid-20 ${ }^{\text {th }}$ Century, sediment size used for the cooperative beach protection program by USACE can be used to illustrate competing viewpoints between industry and the recognition of recreational applications of the peninsula. Sediment size used for beach replenishment activities became central to the debate between USACE and the Pennsylvania.

Initially, USACE used sand from inside the bay to replenish the beaches (Schaney, 2003). However, bay sized sediments were finer grained than those found naturally on the beaches, consequently erosion of bay sediment was faster than expected and discontinued. From 1960 - 1977, coarser material dredged onshore from Holocene 
post-glacial beach ridge deposits of sand with gravel was found to be more resistant to erosion than bay sediment (Stransky and Greene, 1989).

By 1977, concerns for a return to a "natural" state continued to be refined. Even though onshore sediment had the useful effect of slowing beach erosion, it detracted from the recreational appeal of the beaches (Schaney, 2003). As a result of the adverse effects of onshore sediment to recreational activities, by 1987, offshore areas containing finer grained sediment and recreational appeal were used for beach replenishment (Pope and Gorecki, 1982).

Throughout Erie's history, the perception of nature held by citizens and politicians of Erie had incorporated each contradiction contained within the external perspective of a nature. By the end of the $20^{\text {th }}$ Century, the debate on the state of the peninsula began to shift to incorporate a universal perspective of nature viewed as a garden to be tended in order to bring it on-line with human / social experience, combined with external views from a perspective of getting back to nature and returning the peninsula to a more natural state began to dominate. It is this dichotomy between a universal perception of nature and an external vision that has dominated the politics of peninsula to present.

\section{Breakwaters}

By the second half of the $20^{\text {th }}$ Century, local politicians began to argue for a permanent solution to the erosion problems facing the peninsula. Between 1968 and 1985 numerous methods of shoreline sustainability had been considered by the USACE and evaluated for economic feasibility (Gorecki and Pope, 1993). Consideration of 
methods of stabilization included; let nature take its course, construct additional bulkheads and extend the groin field to encompass the entire peninsula shoreline, construct a continuous offshore breakwater, continue beach replenishment or construct a segmented breakwater system (Pilkey and Dixon, 1996). In June 1978, the decision was made to construct three proto-type breakwaters parallel to the shoreline of Presque Isle (Figure 9).

The prototype breakwaters were constructed as an experiment to investigate the spatial variation of littoral transport shoreward of breakwaters (USACE, 2001). The purpose of the proto-type breakwaters was to test the feasibility of a proposed 58 rubblemound segmented breakwater system (Figure 10). The proto-types were also designed to evaluate continued recreational aesthetic of the peninsula while protecting the shoreline by reducing wave energy expended on the beaches (Gorecki and Pope, 1993). Other requirements of the breakwaters included; allowing sand to continue to be transported via longshore drift, an important aspect of breakwater design (Pilkey and Dixon, 1996). USACE hypothesized that, although in reduced volume, sand would continue to be transported behind the breakwaters, preventing the formation of tombolos (Figure 11) resulting in annual sand replenishment activities that would be greatly reduced.

Despite public concerns over aesthetic appeal, and questions concerning their overall effectiveness in shoreline stabilization, Water Resources Development Act of 1986 authorized the construction of a 'permanent solution' to shoreline stabilization with the construction of a 58 rubble mound offshore breakwater system (Figure 10). The construction of the breakwater system sparked intense debate on the future state of the peninsula. Breakwaters were seen by the USACE as a passive, permeable, non-intrusive 


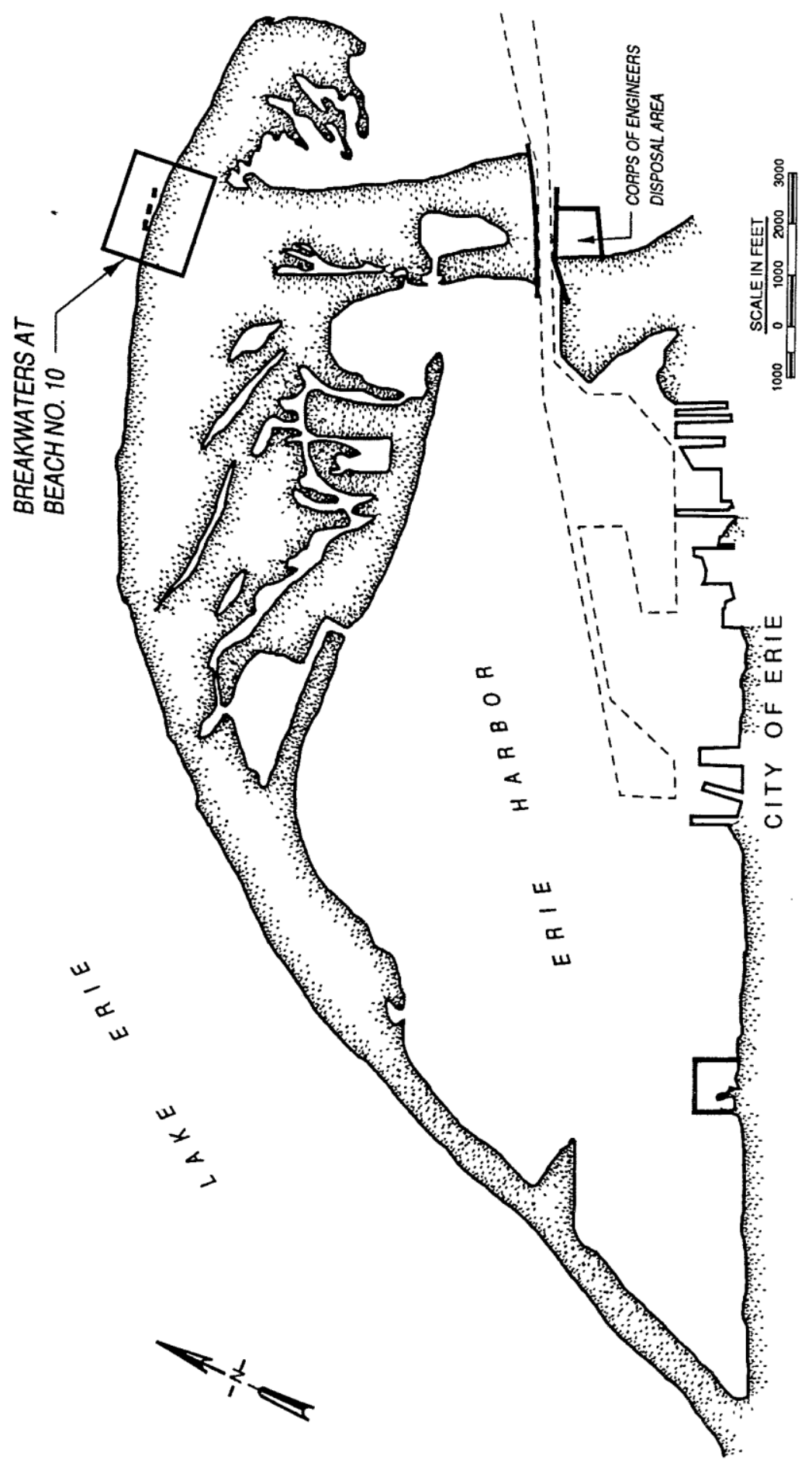

Figure 9: Location of three proto-type breakwaters at beach 10 (Gorecki and Pope, 1993). 


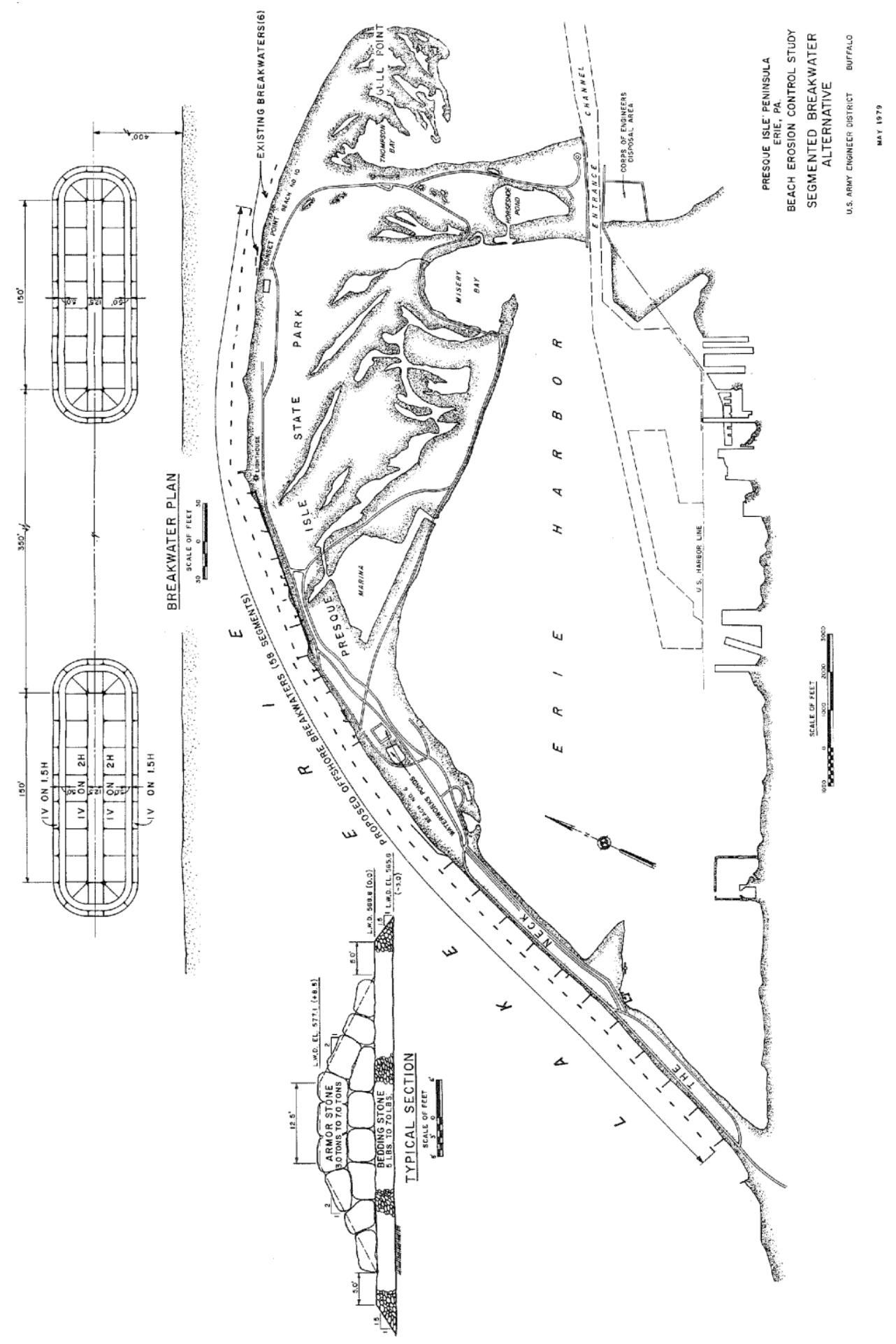

Figure 10: Map of Presque Isle produced by U.S. Army Engineers Buffalo District, highlighting 58 segmented rubblemound breakwater position and construction (Gorecski and Pope, 1993). 


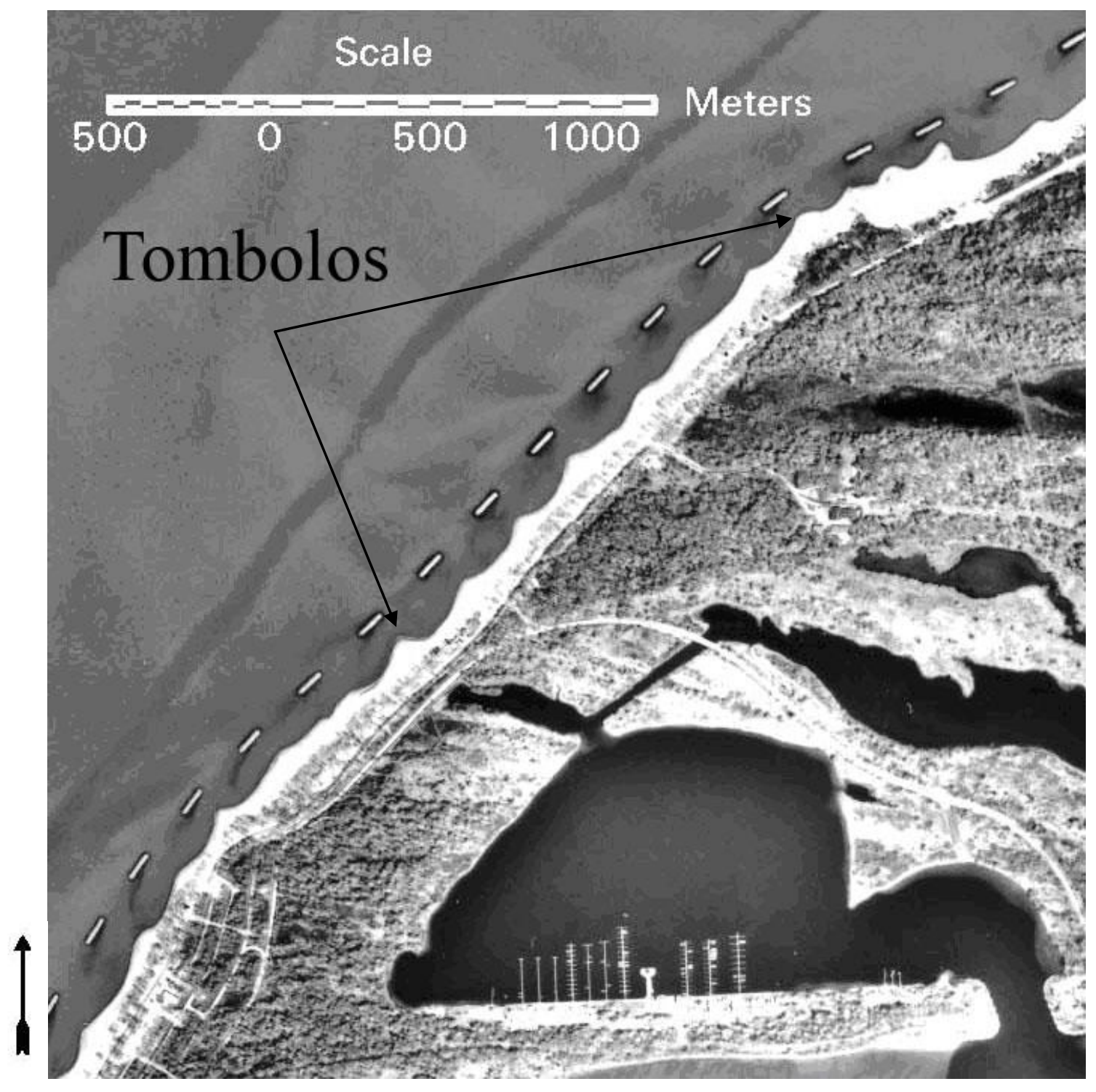

Figure 11: Creation of tombolos shoreward of the breakwaters along the peninsula shoreline (Schaney, 2003) 
permanent solution that would slow, but not stop longshore current (Pilkey and Dixon, 1996). The position of USACE was the breakwaters were advantageous to other methods such as let nature take its course, continued construction of groins, construction of a continuous breakwater and continued beach replenishment (Pilkey and Dixon, 1996). It was believed that natural eastward flow of sand by longshore drift had been significantly reduced due to the construction of Federal harbor structures 20 miles to the west of Presque Isle at Conneaut, Ohio (Gorecki and Pope, 1993). Presence of these structures effectively blocks any littoral material exchange with shorelines to the east. Therefore, the peninsula was considered an area closed to the west and open to the east. Due to the closed nature of the system sedimentation from fluvial, onshore movement of offshore sands or bluff recession sources were viewed as inadequate to sustain the current configuration of the peninsula (Gorecki and Pope, 1993). In light of these factors, USACE formed the position that breakwaters were a permanent, economically sound, environmentally harmless solution for the peninsula (Pilkey and Dixon, 1996).

Opponents of the offshore breakwater system feared that construction of the breakwaters would intrusively violate the park's sanctuary, and disturbance to Gull Point would be detrimental to fragile ecosystems studied by various biologists and environmentalists (Pilkey and Dixon, 1996). Opponents also held the position that a do nothing approach, with exception to periodic nourishment activities would be a more responsible position given the parks natural and environmental sensitivities. According to Pilkey and Dixon (1996): if the USACE would stop all stabilization efforts

\footnotetext{
"yes, erosion would continue, and trees and land would be eroded, but the beach would not be lost". "Doing almost nothing may be a good choice for Presque Isle, where recreational activities are a high priority". "Although shoreline retreat and occasional breaches in the neck would continue, a beach would always be present" (Pilkey and Dixon, 1996).
} 
Proponents of the USACE included then United States Representative from Erie Tom Ridge who was responsible for acquiring funding for the breakwater system (Pilkey and Dixon, 1996). Various other state and local representatives were outspoken in their desire to express their concern and support of saving the peninsula for future generations. The engineering community at large was also staunch supporters. The Buffalo District (responsible for stabilization and maintenance of the peninsula) were awarded the Outstanding Engineering Achievement award by the Michigan Society of Professional Engineers. As summarized in Pilkey and Dixon (1996), the National Society of Professional Engineers announced its award in a 1994 news release stating;

One of the largest projects of its kind, the segmented breakwater design is the result of over 22 years of planning and engineering studies. The project allows the natural movement of littoral sediments and growth of the environmentally sensitive Gull Point to continue. The resulting shoreline is appealing and blends with the natural environment" (Pilkey and Dixon, 1996).

Opponents to the breakwater system included a wide array of Federal, State and Local authorities, as well as the Presque Isle Advisory Committee all of which expressed concern over the aesthetic and functional appeal of the design. Joseph Miller, of the National Park Service, expressed concern over the ecologically sensitive Presque Isle stating; "one of the few areas in the world where ecologists may study the succession of plant life from a sand and water environment to a climax forest within a span of less than one mile" (Pilkey and Dixon, 1996). James Bissell, of the Cleveland Museum of Natural History, was concerned the design would "severely curtail or eliminate the dynamics required for survival of unique beach ecosystems". United States Congressmen Peter Kostermayer of Pennsylvania asked, "Will management strategies stabilize the beach area at Presque Isle and enhance the recreational and intrinsic value of the peninsula, or 
will the projected system destroy the unique geological and ecological features of the peninsula that made it a National Natural Landmark to begin with"? Finally, Pennsylvania State Senator Anthony Andrezeski spoke out against the breakwater design asking the question, "What good will the breakwaters be if they are protecting beaches people can't use" (Pilkey and Dixon, 1996)?

The breakwaters, completed in 1992, were built approximately $120 \mathrm{~m}$ (394 ft) lake - ward of the peninsula shoreline (USACE, 2001). Each structure was positioned in a trough between first and second offshore sandbars, parallel to the shoreline. Each

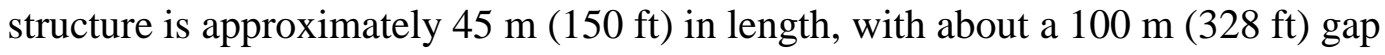
between structures. In addition, 380,000 cubic meters $\left(\mathrm{m}^{3}\right)\left(500,000\right.$ cubic yards $\left.\left(\mathrm{y}^{3}\right)\right)$ of sand fill was placed along the shoreline to provide a recreational beach berm.

Construction of the 58 offshore breakwaters was completed at a cost of approximately 23 million dollars (USACE, 2001).

Since the completion of the breakwaters, a distinctive pattern of erosion and accretion has developed. Accretion of sediment occurs behind the breakwaters causing the shoreline to extend out to the breakwater, a feature known as a tombolo (Figure 11) (USACE, 2001). This pattern of accretion and erosion is undesired because longshore transport is diverted lake - ward of the breakwaters, bypassing the beach and causing down - drift erosion (USACE, 2001). The solution to down - drift erosion has been to excavate material from the zones of unwanted accretion, and recycle the material into the areas of chronic erosion (USACE, 2001). 


\section{Shoreline Response}

Since the construction of the system along the shoreline of the peninsula an erosion / deposition pattern has developed with the formation of tombolos extending lake - ward to the breakwaters (Mohr et al, 1999). The presence of tombolos is detrimental to the Presque Isle shoreline as longshore currents are diverted lake - ward of the breakwater. The result of diverted longshore current causes down-drift erosion and increases the loss of sediment into deep water. Although the formation of tombolos is an undesired effect of breakwater construction, the pattern of erosion and deposition has resulted in a fairly predictable sediment placement program. Since tombolo development, material from areas of unwanted accretion has been excavated and recycled into the areas of chronic erosion (USACE, 2001). As a result of this predictable deposition / erosion pattern, there has been a significant decrease in the annual sand replenishment required on the beaches. Between 1993 and 2001, 26,000 $\mathrm{m}^{3}\left(34,000 \mathrm{y}^{3}\right)$ of sand was placed on the peninsula annually, an order of magnitude less than the preceding decade with a total of over $2,000,000 \mathrm{~m}^{3}\left(2,600,000 \mathrm{y}^{3}\right)(\mathrm{USACE}, 2001)$.

Since construction, the neck (breakwaters 1-19), the shoreline has been stable with no required sediment placement (Mohr et al, 1999). Sediment is typically required around breakwaters in the apex (breakwaters 20-21, 28-30) through the project terminus (breakwaters 34-36, 39-40, 44-58). Through the apex or zone of greatest curvature (breakwaters 20-34), there is more fluctuation in shore position with a range of approximately 44 to $52 \mathrm{~m}$ (144 to $170 \mathrm{ft}$ ). The average distance of the shoreline from the breakwater line throughout the apex is $74 \mathrm{~m}(242 \mathrm{ft})$. Transition from the Apex into the project Terminus (breakwaters 34-58), display significant fluctuation in shoreline 
position, increasing in breadth toward breakwater 58. There is a significant range (94 to $119 \mathrm{~m}(308$ to $390 \mathrm{ft}))$ in the distances from the breakwater to the shore for individual breakwaters and for a single breakwater from year to year (Mohr et al, 1999). From 1975 through 1990, approximately 127,600 cubic meters $(\mathrm{cm})(55,760$ cubic feet (cf)) of beach fill was placed annually (Mohr et al, 1999). During construction (1990-1992), a total of $406,300 \mathrm{~cm}(177,551 \mathrm{cf})$ of initial fill and annual nourishment was placed. From 1993 to 1999, an average annual nourishment quantity of $29,000 \mathrm{~cm}(12,672 \mathrm{cf})$ has been placed. The sediment budget with the project predicted that with the breakwaters, the required annual nourishment amounts would be approximately one-quarter of previous quantities. Comparison of pre- and post-project nourishment quantities reveal that annual nourishment with the project is about 23 per cent of pre-project amounts (Mohr et al, 1999).

\section{SHOALS Analysis}

Three Scanning Hydrographic Operational Airborne Light Detection and Ranging (LIDAR) Survey (SHOALS ${ }^{*}$ ) surveys have been conducted at Presque Isle: in August 1995, July 1997 and June 1998, in order to more completely understand the shoreline response to the detached breakwater system. Data was collected on the dry beach, through the swash zone, onto the breakwaters, and to approximate depths of $7 \mathrm{~m}(23 \mathrm{ft}), 5$ $\mathrm{m}(16 \mathrm{ft})$ and $8 \mathrm{~m} \mathrm{(26ft)}$ for the 1995, 1997 and 1998 surveys respectively. The data has uncovered an erratic coastal system of constantly evolving offshore bars that have been modified by breakwater construction (Mohr et al, 1999). The SHOALS data has revealed offshore bathymetry that is contradictory to earlier studies. Research conducted by

\footnotetext{
${ }^{*}$ For a description of SHOALS operation see Appendix A
} 
Nummedal et al (1984) for example, calculated longshore sediment transport rates under the assumption that offshore bathymetry along Presque Isle consisted of simple shoreparallel contours. However, as shown by the more recent SHOALS analysis, offshore bathymetry is a complex, evolving system.

Offshore bathymetry uncovered by SHOALS analysis along Presque Isle shoreline is as follows; Neck - from the mainland connection of Presque Isle through the vicinity of breakwater 20 , the offshore bars contours parallel the shore in a linear continuous shore-parallel bar system (Figure 12) (Mohr et al, 1999). Patterns of erosion and accretion offshore of the Neck parallel the orientation of the shore with sand transported onshore though the breakwater gaps. The breakwaters enhance the bar field resulting in a stabilized beach. There is little fluctuation in the shoreline and no requirement to replace sediment on associated beaches since project construction (Mohr et al, 1999).

Apex - From breakwater 23 though breakwater 40 the SHOALS data reveal a near shore pattern of shore-oblique linear ridges and troughs as demonstrated by undulating contours (Figure 13) (Mohr et al, 1999). These features are low relief (1 m (3.28 ft)) sand waves that migrate, maintaining the same, approximate 45 degree $\left({ }^{0}\right)$ orientation and a spacing that increases toward the north (higher numbered breakwaters). The result is a linear pattern of annual erosion and accretion in the offshore and greater fluctuation in the nearshore (Mohr et al, 1999).

Terminus - The bathymetry offshore of breakwaters $40-58$ and beyond is progressively more disorganized until the re-curved bar field, unique to Gull Point (Figure 14) (Mohr et al, 1999). The contours suggest an irregular pattern of shoals and 


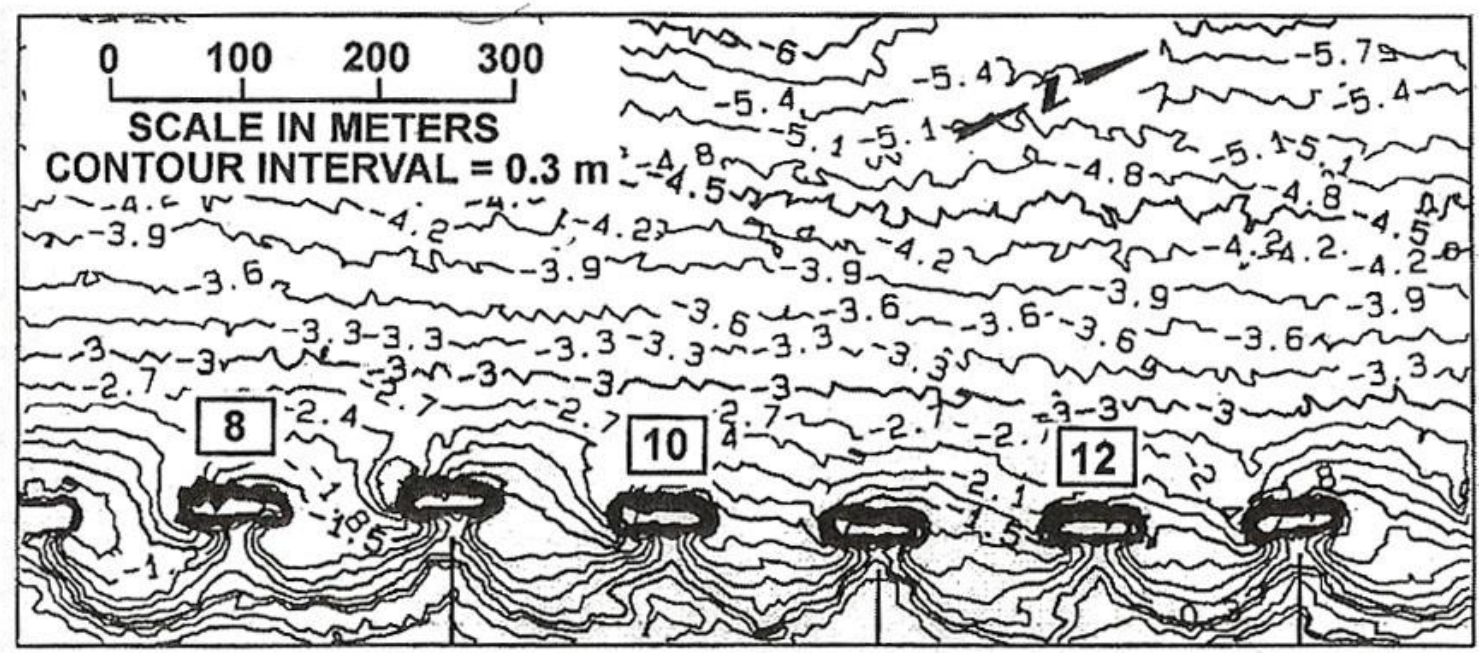

Figure 12: Shoreline bathymetry of the neck of the breakwater system (mainland connection - 20) (Mohr et al, 1999).

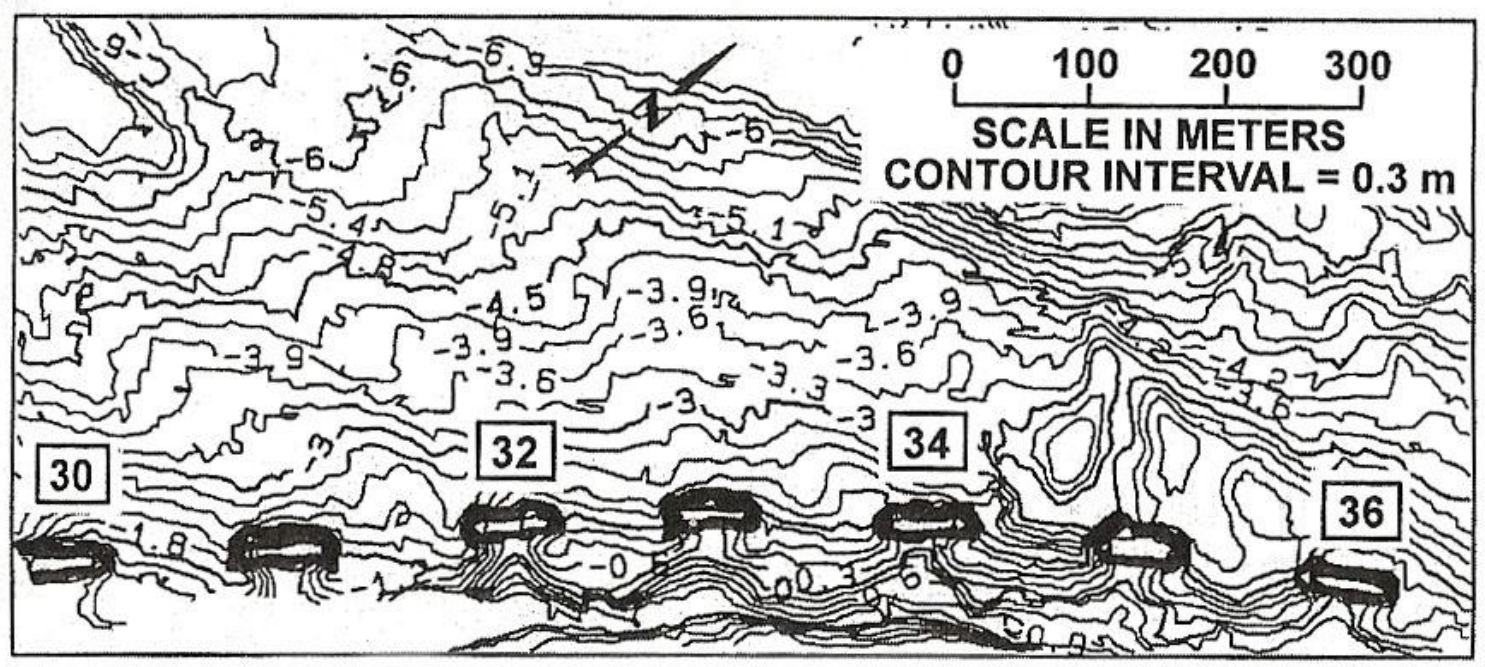

Figure 13: Shoreline bathymetry of the apex of the breakwater system (23-40) (Mohr et al, 1999). 


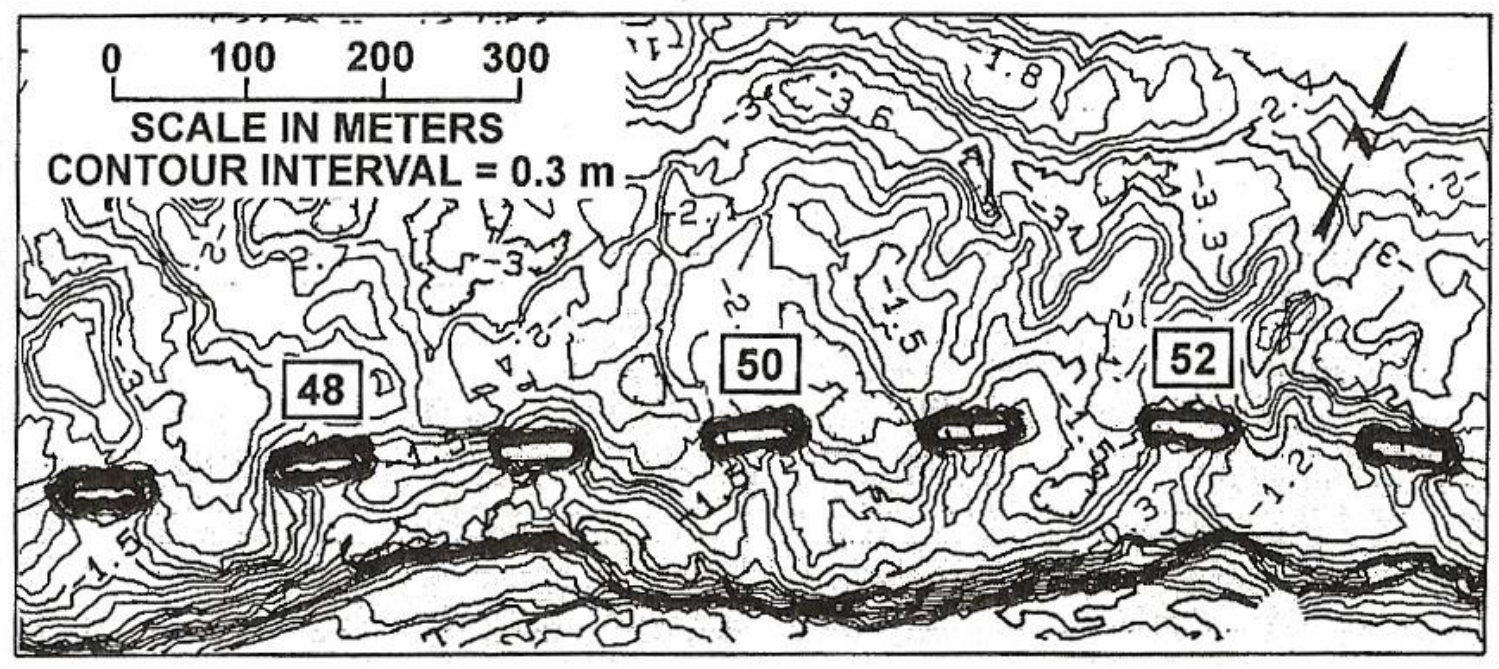

Figure 14: Shoreline bathymetry of the terminus of the breakwater system (40-58) (Mohr et al, 1999). 
depressions that annually change position and shape. The shoals appear to migrate both parallel to and perpendicular to the shore. Four tombolos (at breakwater 44 / 45, 49, 55 and 58) have a tendency to form resulting in a breakwater influence on the nearshore that is reduced by the influences of bathymetry (Mohr et al, 1999)

\section{Focus on Recreation Driven Service Activity}

From the incorporation of Erie until the mid to late $20^{\text {th }}$ Century, the built environment of the City of Erie, made use of the peninsula's inherent maritime capabilities, designed to aid fluidity of resources, commodities and labor from the Great Lakes region, as well as inland points south and west. Rapid revolutions in technology and transportation (canal to railroad, steamship to bulk shipping) tended to undermine structured coherence associated with the harbor. However, each time the economic base was threatened, Erie responded by reproducing the structured coherence associated with Presque Isle, as well as the City of Erie, in order to accommodate revolutions in technology. During the second half of the $20^{\text {th }}$ Century developments in the highway system and the Seaway began to divert industry and commerce away from the harbor signifying and end to predominantly industrial activity associated with the harbor. As the industrial focus began to wane, economic exploitation of the peninsula ushered in a focus on a recreation driven service economy. Evidence of this transition is illustrated by aerial photography of the harbor acquired 6/23/1970, 5/11/1983 and 04/09/1987, from the Eros Data Center (www.eros.usgs.gov) and photography acquired 04/07/1993 and 8/26/2006 from PASDA (www.pasda.psu.edu). ${ }^{*}$

\footnotetext{
* For description of aerial photography, see Appendix B
} 
These aerial photographs illustrate the development of the harbor in response to a recreational focus through the development of the Cascade Docks (Figures 15 and 16). The photograph from 1970 portrays dock facilities that still bear the imprint of past industry. By 1983, recreational dock facilities began to appear to the east of the Cascade Docks. However, during this time period, the Cascade Docks still illustrate an industrially dominant footprint as illustrated by large bulk freighters docked on the western periphery. By 1987, the recreational dock facilities have expanded to the eastern edge of the Cascade Docks, signifying an increasing dependence on recreation and a decrease in an industrial focus. By 1993, recreational dock facilities have completely taken over the Cascade Docks rendering industrial usage of the facilities outmoded. Additionally, the Bayfront Parkway, designed to increase access to the harbor and associated recreation facilities, can be viewed for the first time. By 2006, Cascade Docks had been completely transformed to reflect an economic focus driven by recreation. Although the peninsula was produced and maintained primarily to support industrial based economic exchanges, the produced environment of the peninsula has enabled the City of Erie to reproduce the structured coherence of the region as a place oriented around recreation and service.

In response to the economic transition towards a recreation driven service economy, the City of Erie exemplified its cultural and physical forms. These cultural / physical forms highlight Erie's maritime tradition, manufacturing history, the geo-history of natural processes, unique natural ecosystems, as well as engineering activities associated with the peninsula. All of these place specific attributes give the City of Erie a uniqueness that has enabled the economy to adapt and evolve in the wake of crisis. 

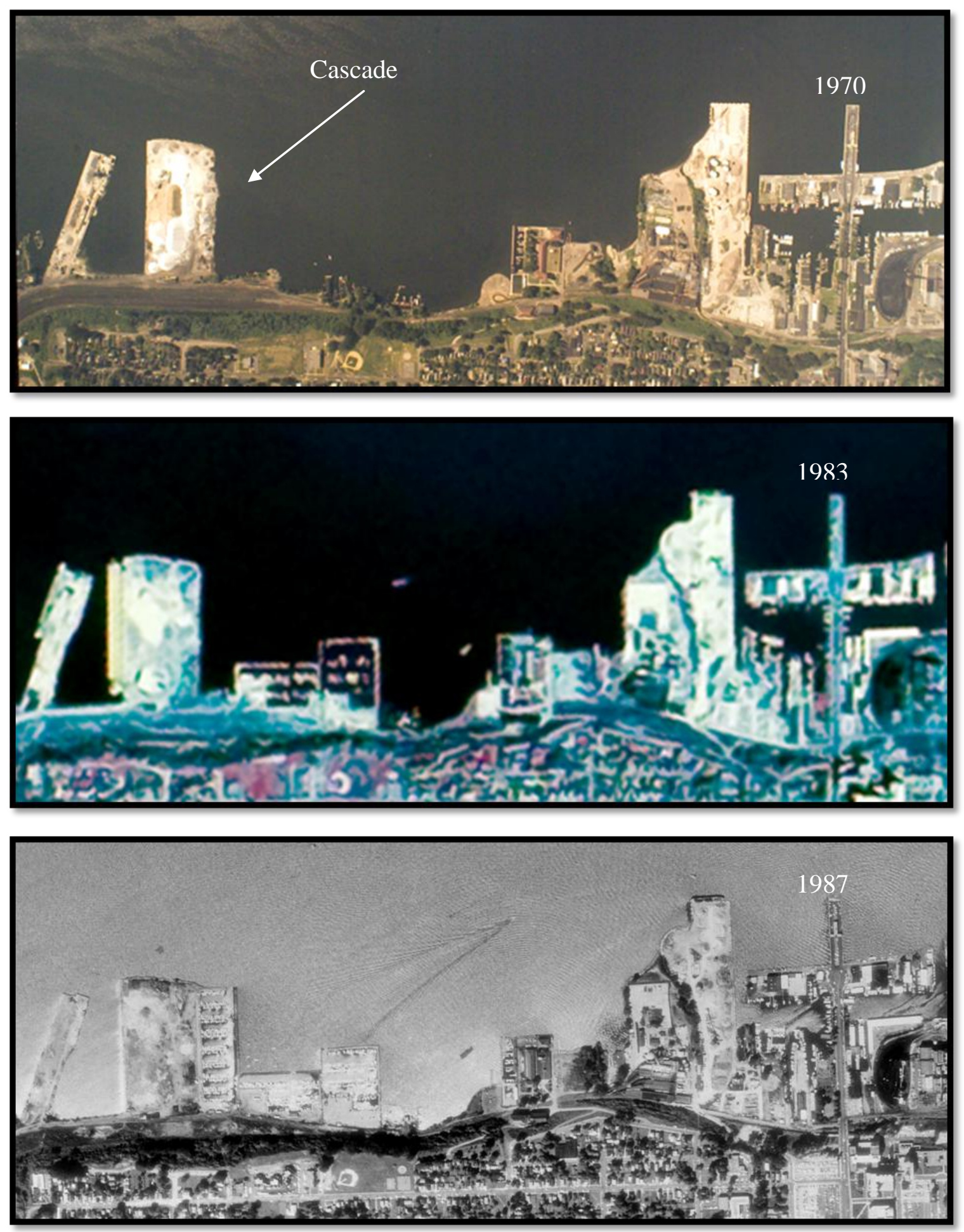

Figure 15: Aerial photography from 1970, 1983 and 1987 illustrating the transition from industrial to recreational usage of the harbor (www.eros.usgs.gov). 

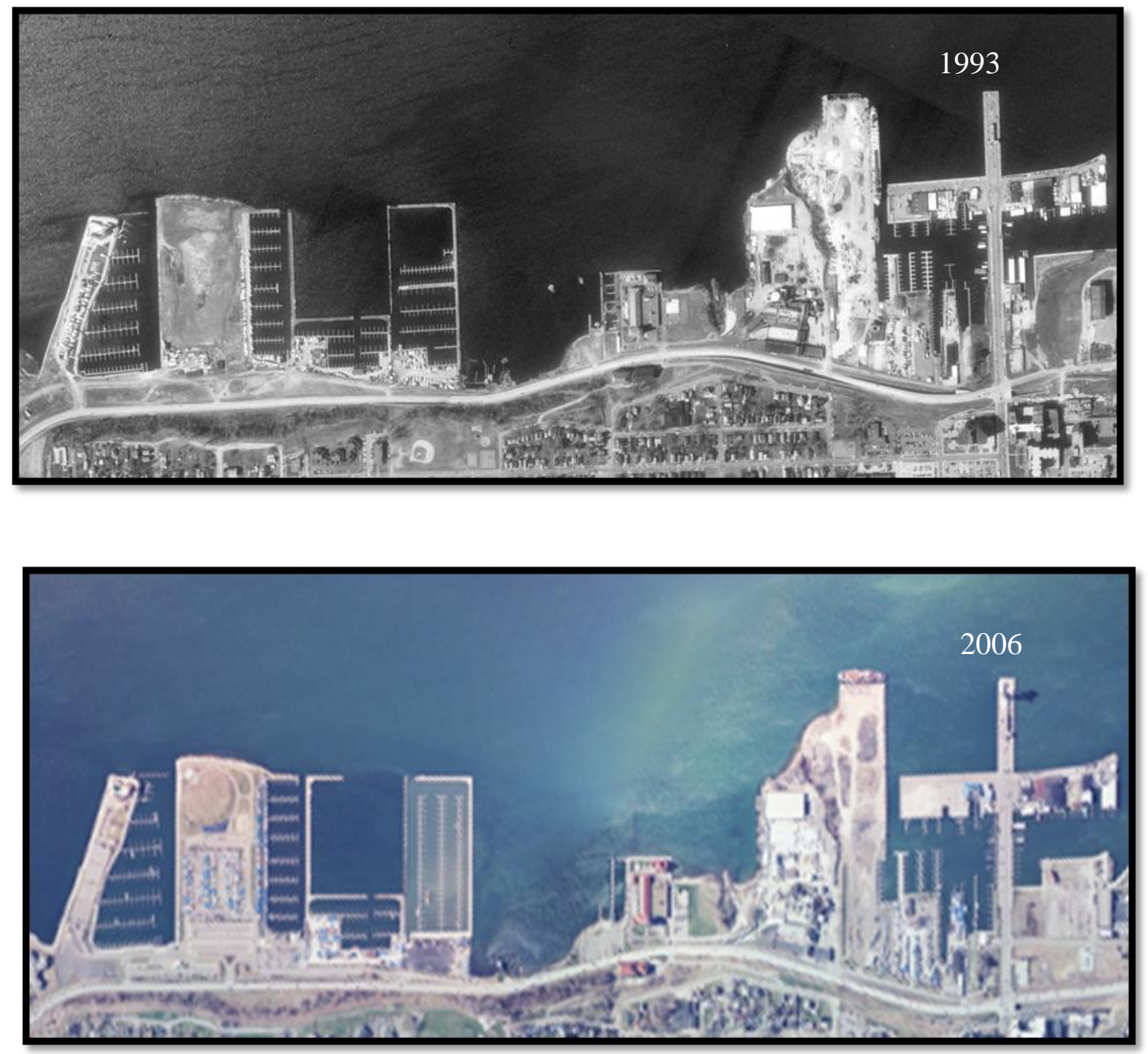

Figure 16: Aerial photography from 1993 and 2006 illustrating the transition from industrial usage to recreational usage of the harbor (www.pasda.psu.edu). 
In addition, the pressures of globalization and associated decline of traditional Fordist based industry within the larger Great Lakes region, the City of Erie was forced to reinvent itself and promote a good business climate. In response, Erie and Presque Isle have become an important recreation destination catering up to four million visitors each year. Presque Isle harbor is now home to a multi-million dollar waterfront development and the new Erie Maritime Museum, which houses the U.S. Brig Niagara, the flagship of the fleet built in Erie during the War of 1812. Service based economic activity on the harbor continues with the biggest development project in Erie's history. Construction began in April 2001, when former Governor Tom Ridge and Pennsylvania presented the Erie County Convention Center Authority with $\$ 32$ million to fund the Bayfront Convention Center.

Evidence of the growth of a recreation driven service economy within the City of Erie, predominantly in the form of shopping areas, chain restaurants and gaming has been illustrated by the use of Geographic Information Systems (GIS) and remote sensing technologies ${ }^{*}$. Additionally, evidence of this transition is illustrated by aerial photography of major service areas acquired 6/4/1977 and 5/11/1983, from the Eros Data Center (www.eros.usgs.gov) and photography acquired 04/07/1993 and 04/16/2005 from PASDA (www.pasda.psu.edu) ${ }^{\dagger}$

These aerial photographs illustrate the development of service in response to a recreational focus through development along the interchange of I-79 and Peach Street (Peach), as well as along the interchange of I-90 and Peach. The photograph from 1977 portrays the retail area associated with the Millcreek Mall between Peach and I-79

\footnotetext{
${ }^{*}$ For a description of GIS and remote sensing technology used for this research see Appendix B

${ }^{\dagger}$ For description of aerial photography, see Appendix B
} 
(Figure 17). The 1977 photograph also shows limited development along the interchange of Peach and I-90. The Photograph from 1983 illustrates a similar service oriented footprint at the interchanges of I-90, 79 and Peach (Figure 18). By 1993 however, service begins to expand along the I-90 / Peach interchange (Figure 19). This change is illustrated by the growth in development on the western side of Peach. Furthermore areas of growth can be seen south of the Millcreek Mall complex on the eastern side of Peach. By 2005, major expansion in service areas can be viewed along the interchanges along I79 and 90 (Figure 20). The Millcreek Mall has expanded westward to I-79 right of way. Additionally major service areas have expanded east of Peach along the I-90 interchange, as well as, south of I-90 and Peach. Growth of service oriented areas between 1983 and 1993 is evidence of an increasing dependence on a recreation driven service economy in response to a waning industrial focus. Although not shown on the aerial photography, the completion of Presque Isle Downs and Casino February 28, 2007 at the interchange of State Street (State) and I-90 three miles to the east further illustrate this transition.

Investigation of changes in the built environment associated with the City of Erie and surrounding municipalities (Figure 21) have employed two Landsat 5 Thematic Mapper (TM) images dating October 3, 1984 and September 17, 2007. These dates were chosen because they effectively illustrate the time period of the last economic transition from an industrial economic focus to one centered on recreation driven service. The 1984 image was chosen because it represents the beginning of the physical transformation in land use within the harbor associated with City of Erie from an economy dominated by industry to one that reflects the current recreational / service focus. 


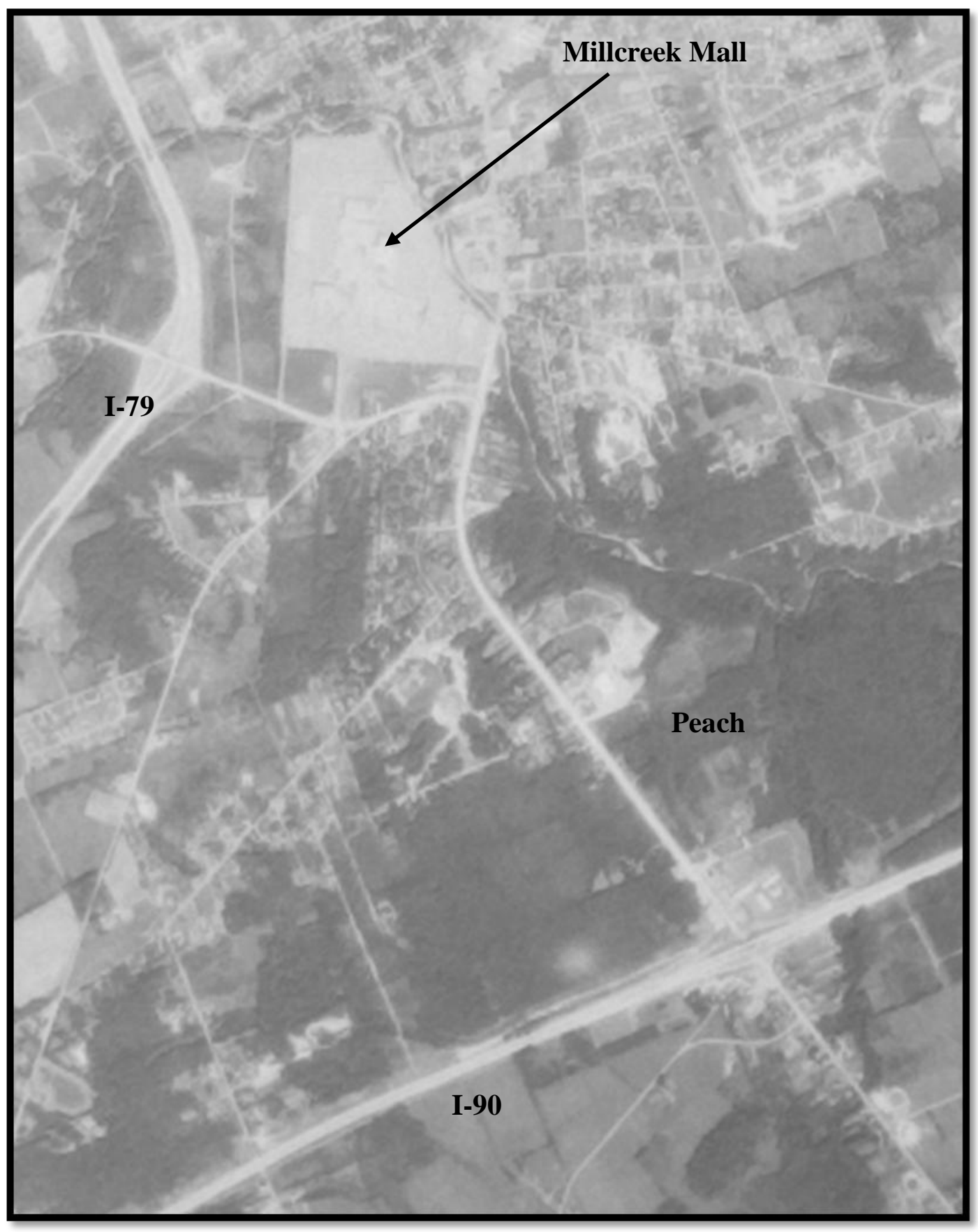

Figure 17: Aerial photography from 1977 illustrating major areas of service along the I79, 90 and Peach corridors (www.eros.usgs.gov). 


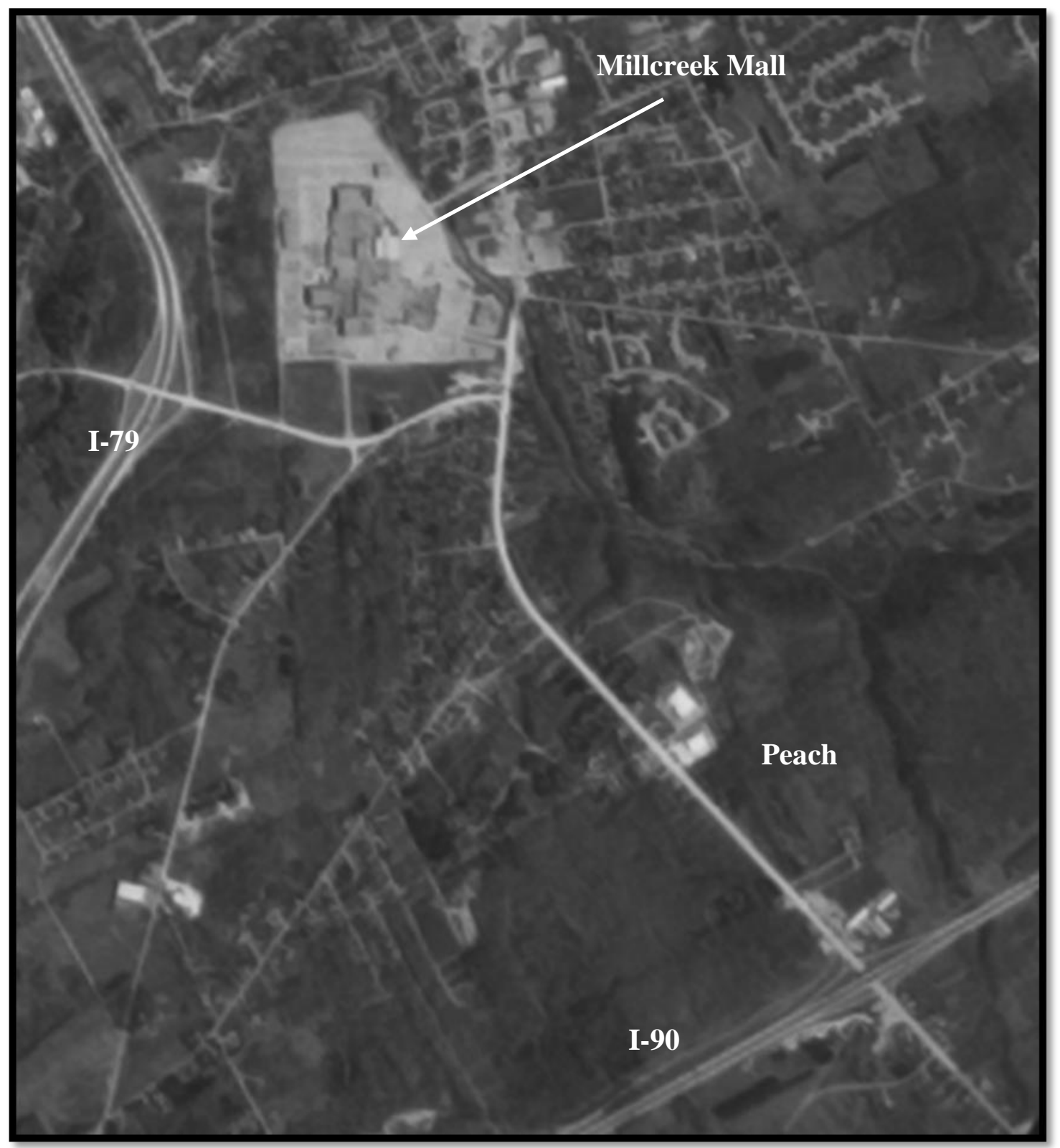

Figure 18: Aerial photography from 1983 illustrating major areas of service along the I79, 90 and Peach corridors (www.eros.usgs.gov). 


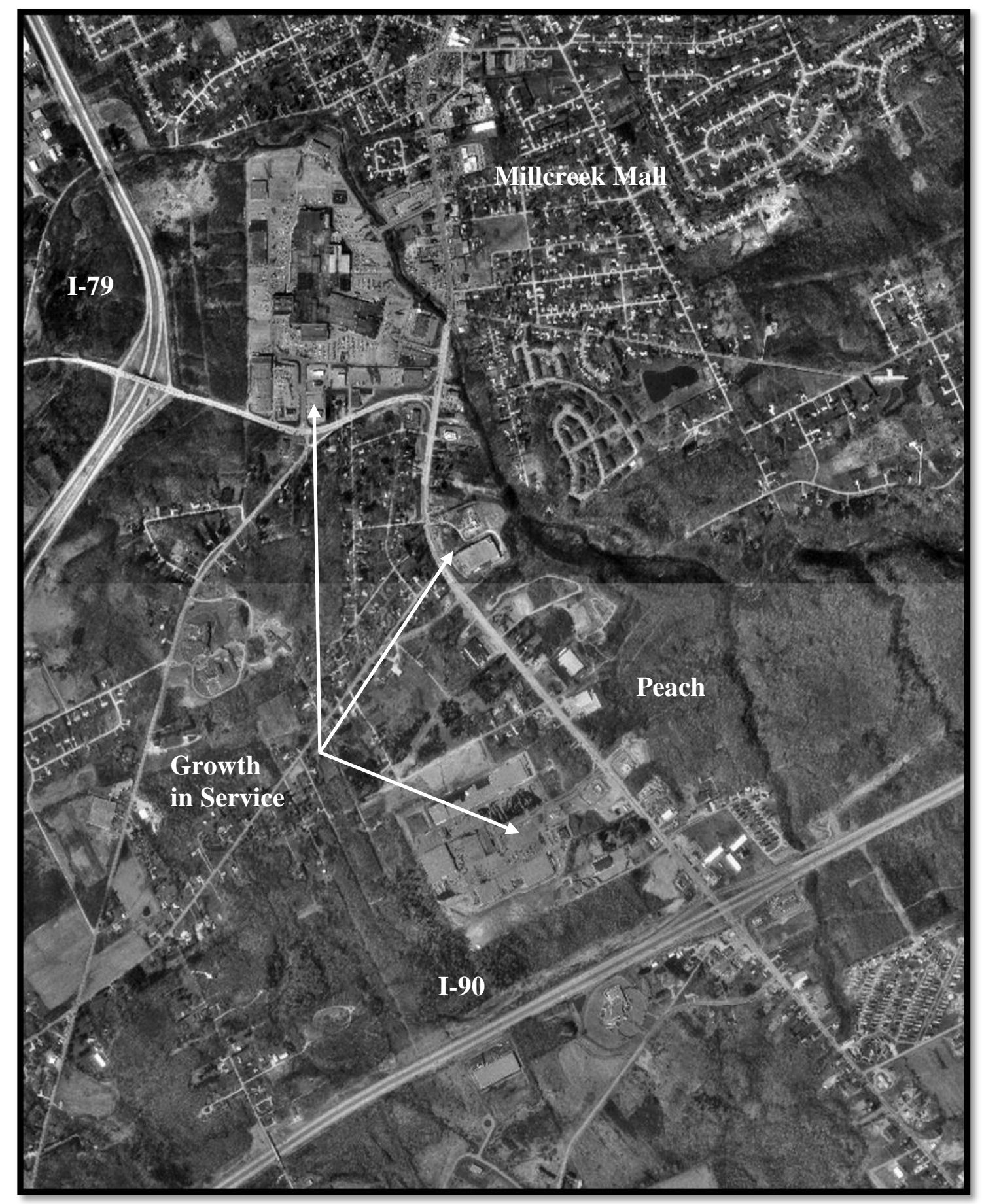

Figure 19: Aerial photography from 1993 illustrating growth of major areas of service along the I-79, 90 and Peach corridors (www.pasda.psu.edu). 


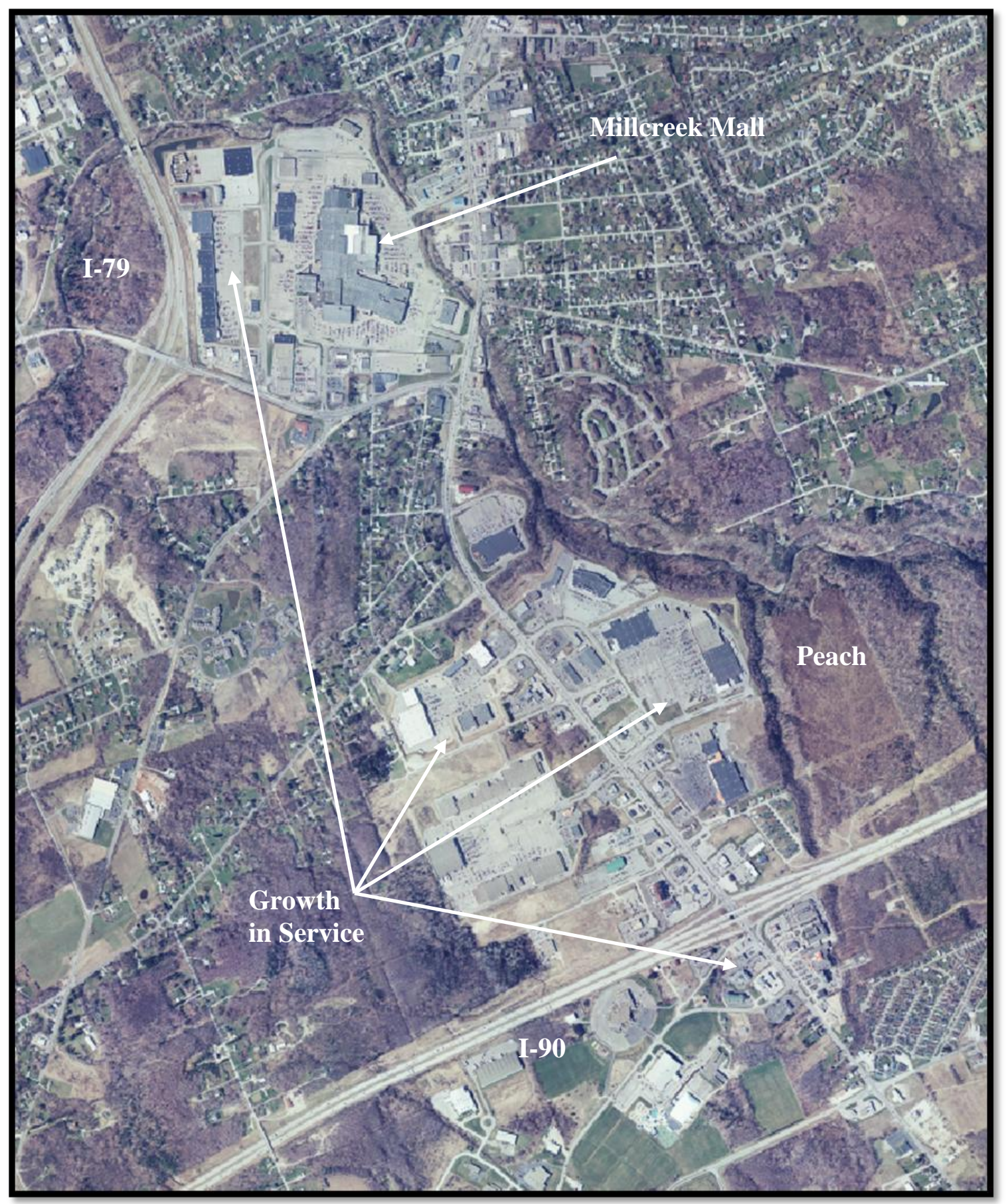

Figure 20: Aerial photography from 2005 illustrating growth of major areas of service along the I-79, 90 and Peach corridors (www.pasda.psu.edu). 


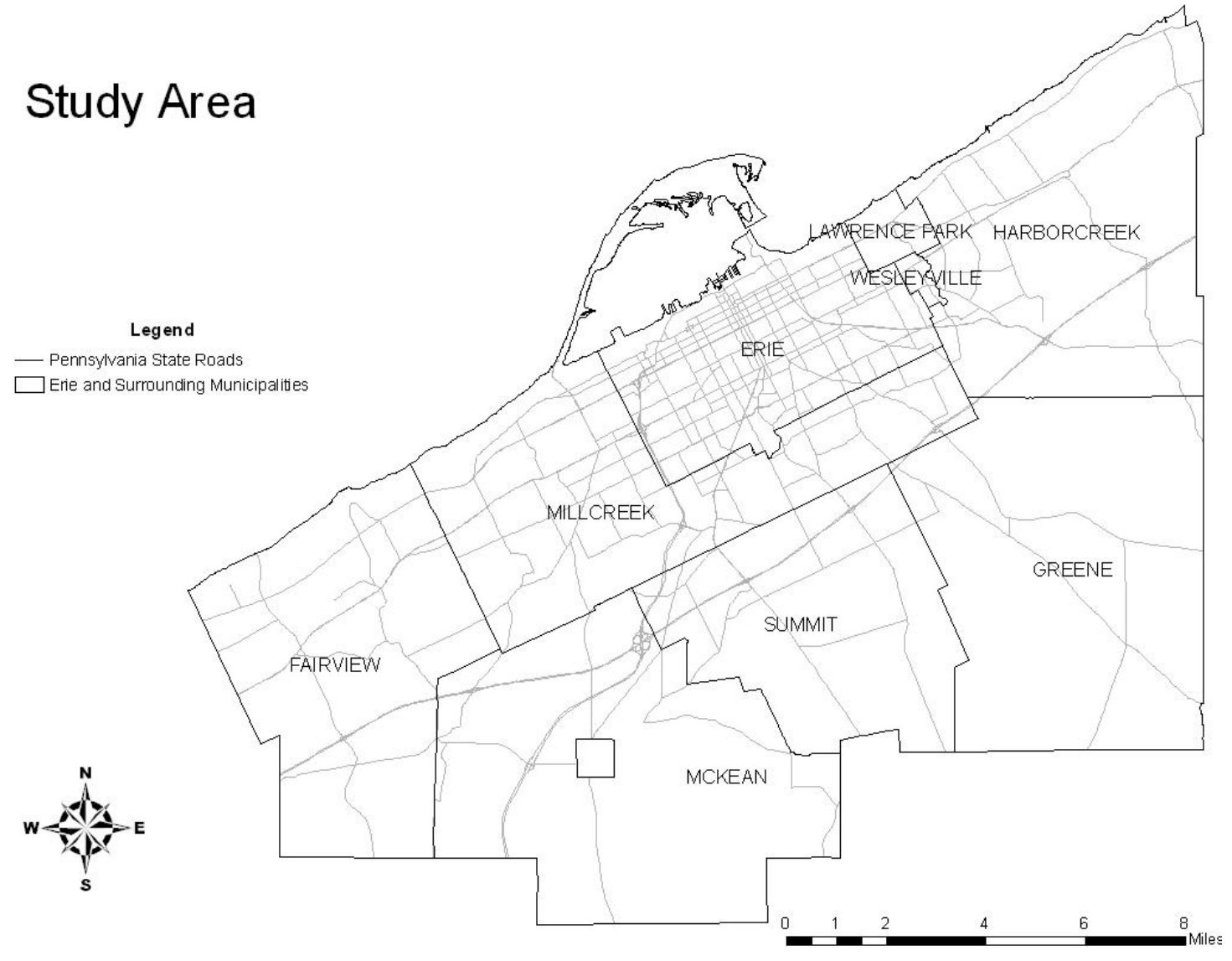

Figure 21: Study Area. 
Although the 1983 aerial photography (Figure 15) demonstrates a small recreational facility within the harbor area, industrial facilities remain unaffected by the transition to recreation. The $1984 \mathrm{TM}$ image was found to be appropriate documentation of land use within the City of Erie reflective of an industrially focused economy. The 2007 TM image was chosen because the last major recreational / service development, Presque Isle Downs and Casino completed in February of 2007, is represented on the image. The 2007 image represents a "snapshot" of land use associated with the current state of recreational based service economy that dominates at present. As stated above, these TM images served as bookends representative of land use / land cover changes within Erie. Polygons delineating industry and service areas with in the City of Erie were constructed based on a-priori knowledge of the economic framework associated with the City of Erie, as well as the above mentioned aerial photography.

Using the above techniques to delineate and identify the land use in 1984, an industrial footprint was still dominant within the harbor as illustrated through aerial photography. Other major concentrations of industry were found, along Route (Rte) 5 and State (Figure 22). Major industrial areas within the City of Erie in 1984 comprised an area approximately 6,869,500 square meters (sm) (1,690 acres (a)). Major areas of service in 1984 tended to be located around the periphery, focused on I-79 and Peach St. Major areas oriented around service comprised approximately 954,500 sm (235 a). The total area of combined major industrial / service land use in and around the City of Erie in 1984 was approximately 7,824,000 sm (1,930 a). 


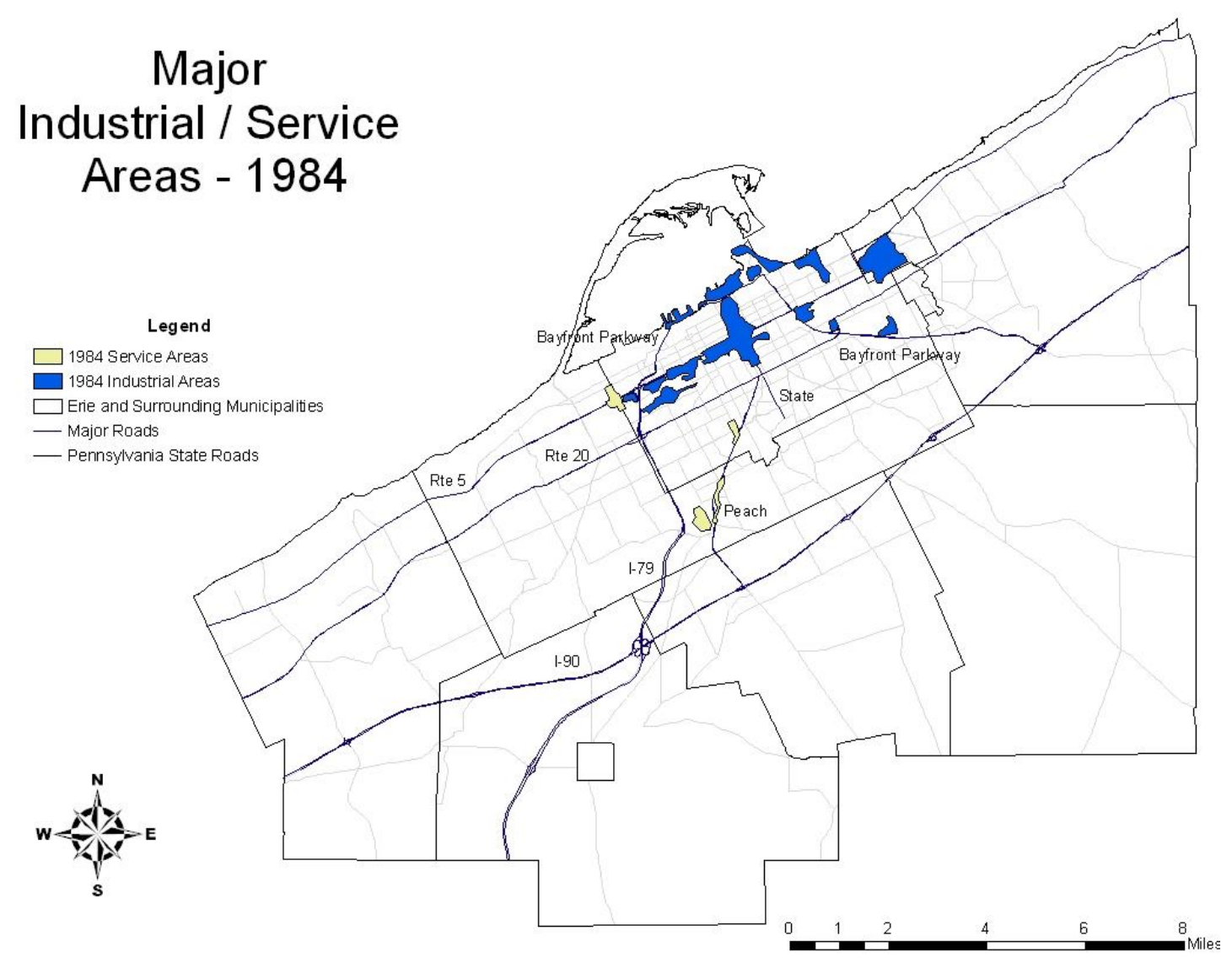

Figure 22: Major areas of Industrial / Service land use locations - 1984. 
By 2007, the old industrial footprint of the harbor had been completely transformed into a place focused on recreation (Figure 16). Industrial areas in 2007 in and around the City of Erie have contracted to approximately 5,989,880 sm (1,480a) (Figure 23). Concentrations of industry are still located on Rte 5 and State. Over the same time period, major areas in and around the City of Erie dedicated to service increased to $6,016,890 \mathrm{sm}(1,490 \mathrm{a})$. Major areas of service are still located around the periphery. However, service based land use has expanded to include areas on I-90 and Peach, I-79 and Peach and I-90 and State. The total area of combined major industrial / service land use in and around the City of Erie has increased to approximately 12,006,770 $\operatorname{sm}(2,970 \mathrm{a})$.

Erie's response to destabilized structured coherence brought about by the affects of globalization and revolutions in transportation, diverted commerce away from the harbor associated with the peninsula. The economic response by the City of Erie has been to diversify and develop recreation driven service based economic opportunities. This transition is manifested by a transformation of the harbor from an industrial focus to recreation, as well as an expansion of service oriented land use within the greater region surrounding the City of Erie. Overall, the response of the City, in an attempt to reproduce the structured coherence of the region during the last economic transition, has been to divert recreation driven economic activity away from the harbor (Figure 24). In 1984 the mean center of service based economic activity was located approximately 4.3 $\mathrm{km}(2.7 \mathrm{mi})$ south of the harbor. By 2007 the mean center of commerce had shifted southward to approximately $5.1 \mathrm{~km} \mathrm{(3.2} \mathrm{mi)} \mathrm{south} \mathrm{of} \mathrm{the} \mathrm{harbor.} \mathrm{Over} \mathrm{all,} \mathrm{for} \mathrm{the} \mathrm{time}$ 


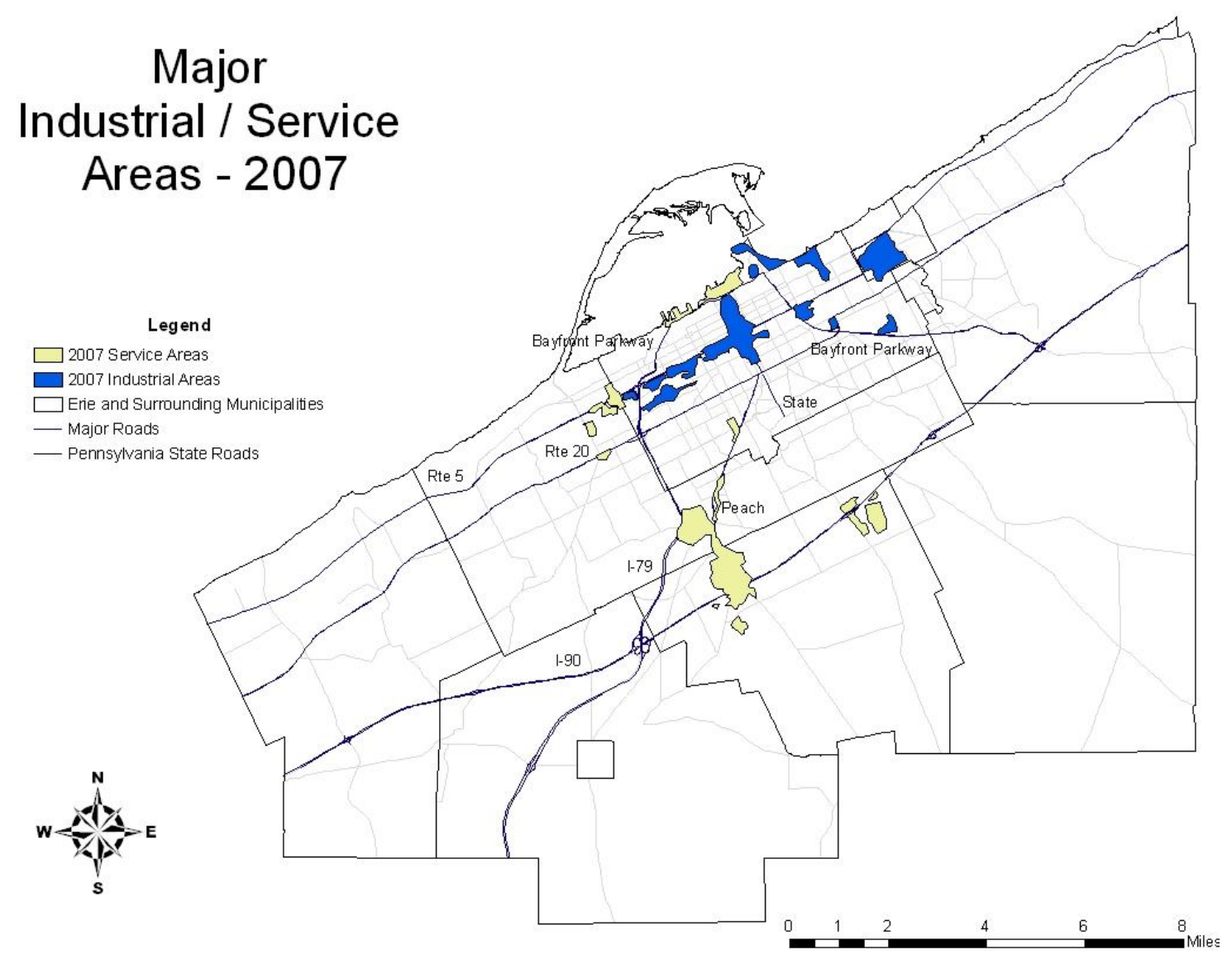

Figure 23: Major areas of Industrial / Service land use location - 2007. 


\section{Mean Center of Industry / Service}
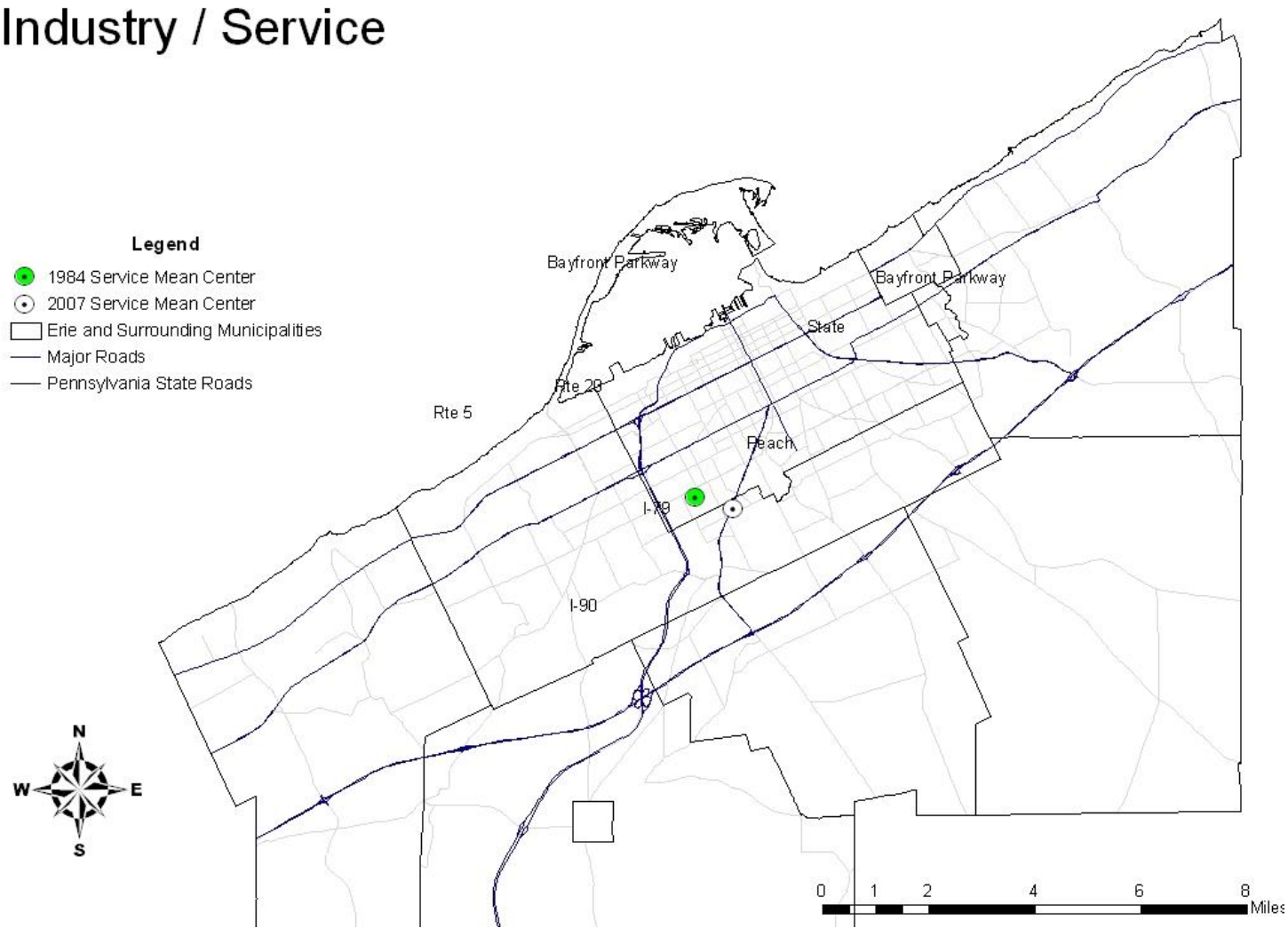

Figure 24: Mean center of Industry / Service 1984 / 2007. 
period of 1984 to 2007 the mean center of commerce had shifted southward approximately $1.9 \mathrm{~km}(1.2 \mathrm{mi})$ reflecting the transition to service based economic activity

In conclusion, understanding the production of space in context of the City of Erie and its dependence on Presque Isle cannot be fully understood without investigation of historical - geography of place. Illustrating real versus perceived views of nature within a greater capitalist framework, the ability to overcome crisis, reproduce structured coherence within the context of place, have formed the basis of shifting perceptions toward the natural aspects of the peninsula.

\section{Natural Processes and Place}

During the Industrial era, engineering practices performed on Presque Isle were driven by shoreline armoring techniques. These techniques included hard shoreline protection structures included; groins, riprap, tree planting and gravel size sediment. During the Recreation era, these approaches were modified to incorporate recreational activities in support of a service based economy. These techniques included continued shoreline armoring practices with the construction of 58 rubblemound breakwaters, as well as, an incorporation of soft approaches in the form of sand replenishment, sensitive to recreational needs. Although natural processes are still taking place on the peninsula, its connection to Erie's economic vitality and continued structured coherence has not been diminished with the wane of an industrial focus. Instead, engineering practices on the peninsula have been modified to reflect changing social / economic exploitation. 


\section{Social Processes and Place}

Although Presque Isle has always played an important role in the continued economic success of the City of Erie, since the mid- $19^{\text {th }}$ Century, public perception of the use - value of the peninsula shifted from a primarily industrial use, to one more focused on recreation. This increased reliance on a recreation driven service economy is evident on the landscape by the growth and distribution of service based areas, in and around the City of Erie. The use of GIS technologies has been an effective tool illustrating the effect of the economic transition on the landscape. Between 1984 and 2007, land dedicated to service based land use grew 5,062,390 sm (1251a), while areas dedicated to industrial based land use over the same time period, contracted by $879,620 \mathrm{sm}$ (217 a). In addition, economic activity has shifted away from the harbor, southward approximately $1.9 \mathrm{~km}$ (1.2 mi). Southward movement of economic activity associated with Erie is reflective of the importance of the interstate highway system. A majority of the new service dominated areas are located on I-90 and 79. This transition of economic areas from one location to another has been the most dramatic example of social / economic impact and the production of place during the last economic transition.

Additionally, the exemplification of Erie's cultural forms during this time period is further evidence of this social / economic transition. During the last economic transition the harbor front of Presque Isle has been transformed from heavy industry closely associated with shipping to one that exemplifies Erie's rich maritime tradition. Further evidence of the completeness of this transition can be seen in the opposition demonstrated against the decision by USACE to construct 58 rubblemound breakwaters. From the average citizen, to scientists and politicians it was feared that damage caused by 
the construction would negatively affect the sensitive natural resources found on the peninsula, as well as unique recreational activities.

\section{Natural-Social Interdependencies and Place}

The story of the construction of place within the City of Erie can only be developed through careful examination of the creation of place and the built environment structured within the dynamics of a capitalist framework in light of a physical setting that, in the case of Erie, promotes the reproduction of structured coherence in the wake of economic crisis. During the economic crisis of the latter half of the $20^{\text {th }}$ Century the economy of Erie transitioned from one dominated by industrial activity to one focused on a recreation driven service economy. This transition has been made possible by the dual role the peninsula has played throughout Erie's history. The ability of the peninsula to annually attract up to four million visitors has enabled the City of Erie to develop a service based economy catering to those visitors. Although recreation based developments have taken place within the harbor, the service based development within the City of Erie has primarily taken place along the interstate highway system south of the harbor.

Set within the construct of a constellation of relations, in the context of competing views of external and universal perceptions of nature, the produced environment of Presque Isle has been transformed from a first nature state to one that reflects the combination of competing attitudes towards a landform constructed solely for the purpose of serving industrial interests with viewpoints aimed at preserving a "natural" aesthetic of the landscape in order to serve the pleasure of its visitors. Each of these 
viewpoints have come together to form an ideology that has constructed not only the social production of Presque Isle, but also changes in urban form associated with the City of Erie. 


\section{Chapter 6: Conclusion}

This research has been designed to demonstrate the interconnectivity of social processes associated with the City of Erie and natural process at work on Presque Isle. The emphasis on the above interconnectivity has been to demonstrate how the two have converged to produce space and create place. From a historical perspective, this research illustrates that the ability of the City of Erie to adapt to changing economic patterns and reproduce structured coherence has been in large part, due to the presence of Lake Erie and more specifically Presque Isle.

The changing role of the peninsula as driver of economic activity and the reproduction of structured coherence has also had a dramatic effect on how the peninsula shoreline has been used and maintained. During industry dominant use of the harbor, shoreline maintenance structures were constructed with the intention of maintaining a stable environment for industrial activities. As the industrial period began to wane in the latter half of the $20^{\text {th }}$ Century, new engineering techniques were initiated that incorporated a recreational vision of the landscape.

In addition to socio-economic forces, natural physical forces that shape the peninsula and the coastline such as erosion, lake level, longshore drift, etc. play an important role in the reproduction of structured coherence. As seen in the case of Erie and the region, the devaluation of capital in association with crisis does not necessarily destroy the use value. The physical resource, in this case the peninsula, combined with socially produced space has been historically devalued several times, only to emerge as devalued capital which has been paramount in the reproduction of structured coherence 
and renewed accumulation. In the case of Erie, place specific context of physical processes combined with the socio-economic forces associated with capitalism examined together achieve a more holistic understanding of the production of space.

The use of spatial technologies in this research, have aided the historical understanding of place and how the transition from industry to service has manifested itself during the period of the last economic transition. The use of Landsat imagery in a GIS environment in cooperation with an a priori knowledge of the City of Erie and surrounding region allowed for useful identification of areas of industry and service over the last economic transition.

In conclusion, I feel that this geographical research is a valuable resource with regard to continued conceptualization of the relationship between social and physical processes, the creation of place and the production of space. Through the use of spatial technologies, this research has strived to improve our understanding of the dynamic environment of urban form in the context of an examination of the relationship between physical process and temporally specific economic activities associated with Presque Isle and the City of Erie.

I feel that this research has made a positive contribution to geographic literature through conceptualization of the merging of an understanding of how capitalist activity actively creates socially produced, profit driven landscapes that are maintained in order to facilitate continued capitalist activity. In addition, the temporal framework within which this research was constructed, demonstrates the resistance of genuinely natural forces to conform to the capitalist ideal. 
In closing, I believe that the investigation of Presque Isle and the City of Erie performed for this research offer insight into landscape modification within a greater capitalist context. Although recent geographic thought has treated issues associated with social and physical processes as separate entities, I feel that this research has made a valuable argument that understanding the evolution of space cannot be removed from an investigation of both processes in our attempts at reconstructing a more complete conceptualization of place. 


\section{$\underline{\text { References }}$}

Agnew, J. 1987. Place and politics: the Geographical mediation of state and society. Allen and Unwin, Boston, Massachusetts.

Agnew, J. 1993. Representing space: space, scale and culture in social science. In Place / Culture / Representation. Duncan, J. and D. Ley Eds. Routledge, New York. pp. $251-71$.

AMVETS Memorial Highway I-90. http://www.pahighways.com/interstates/I90.html.

Assel, R. A., F. H. Quinn and C. E. Sellinger 2004. Hydroclimatic factors of the recent record drop in Laurentian Great Lakes water levels. American Meteorological Society 85(8): 1143-1151.

Ballert, A.G. 1953. The Great Lakes coal trade: present and future. Economic Geography,29,1. pp. 48-59.

Birdsall, S.S, E.J. Palka, J.C. Malinowski and M.L. Price 2009. Regional Landscapes of the United States and Canada. $7^{\text {th }}$ Ed. John Wiley and Sons.

Bloom, A.L. 1991. Geomorphology: A Systematic Analysis of Late Cenozoic Landforms. Prentice Hall. Edgewood Cliffs, New Jersey.

Buyce, R. M. 2005. Lake Erie Bluff Geology. Mercyhurst College Erie, PA: Powerpoint Presentation.

Carter, C. H., W. J. Neal, W. S. Haras and O. H. Pilkey Jr. 1987. Living with the Lake Erie Shore. Duke University Press, Durham, NC.

Castree, N. 1995. The nature of produced nature: materiality and knowledge construction in Marxism. Antipode 27:1.

Castree, N. 2001. Social Nature: Theory, Practice and Politics. Castree, N. and Braun, B. eds. Blackwell Publishers Inc. Malden, Massachesetts.

Congalton, R. G. and K. D. Green 1999. Assesing the Accuracy of Remotely Sensed Data: Principles and Practices. Lewis Publishers, Boca Raton, FL.

Cusmano, M.A. 1985. TheJjapanese automobile industry. Harvard University Press, Cambridge, Massachusetts.

Dawson, S.A. and J.E. Evans. 2001. Geological Causes of Local Variation in Coastal Bluff Recession Rates, Northeast Ohio Shoreline of Lake Erie. Environmental Geosciences, Vol. 8 No. 1. 
DeGeorge, J.E. 1975. The commercial development of Erie County 1810-1825. The Journal of Erie Studies. Vol. 4, No. 1.

Drescher N.M. 1982. Engineers for the Public Good: A History of the Buffalo District U.S. Army Corps of Engineers. J.R Martin-Diaz (Ed.) Buffalo, New York: United States Army Corps of Engineers, Buffalo District.

Erie County Unit of the Federal Writers' Project of the Works Progress Administration for the Commonwealth of Pennsylvania. 1938. Erie; A Guide to City and County. The William Penn Association; Philadelphia, Pennsylvania.

Gorecki, R.J and J. Pope 1993. Coastal geologic and engineering history of Presque Isle Peninsula, Pennsylvania. U.S. Army Corps of Engineers, Buffalo District Buffalo, New York.

Goudie, A.S. 2000. The dictionary of physical geography. Thomas, D.S.G. and A.S. Goudie eds. Blackwell, Malden, Massachusetts.

Guenther, G.C., Brooks, M.W. and P.E. LaRocque 2000. New capabilities of the SHOALS airborne LIDAR bathymeter. Remote Sensing of the Environment. vol. 27 no. 2, pp. 95-108.

Guy, D.E. Jr. 1995. A preliminary assessment of recession rates on the bluff at Painesville-on-the-Lake. In D.W. Folger ed., Proceedings of the 3rd Annual Lake Erie Coastal Erosion Study Workshop (pp. 24-28). St. Petersburg, Florida: U.S. Geological Survey Center for Coastal Geology.

Fung, T. 1990. An assesment of TM imagery for land-cover change detection. 1EEE Transactions on Geoscience and Remote Sensing 28: 681-684.

Harvey, D. 1985. The geopolitics of capitalism. St. Martin's Press, New York.

Harvey, D. 1987. Flexible accumulation through urbanization: reflections on 'postmodernism' in the American city. Antipode 19(3): 260-286.

Harvey, D. 1990. Between space and time: reflections on the geographical imagination. Annuls of the Association of American Geographers 80(3): 418-434.

Harvey, D. 2002a. The Urban Process Under Capitalism: A Framework for Analysis. Blackwell Publishers, Malden, MA,.

Harvey, D. 2002b. From Managerialism to Entrepreneurialism: The Transformation in Urban Governance in Late Capitalism. Blackwell Publishing, Malden, MA.

Harvey, D. 2003. The New Imperialism. Oxford University Press, Oxford, U.K. 
Innes, J. 1992. Forest decline. Progress in Physical Geography. 16.

Jensen, J. 1981. Urban change detection mapping using Landsat digital data. The American Cartographer 8: 127-147.

Jensen, J. R. 1996. Introduction to Digital Image Processing: A Remote Sensing Perspective. Prentice Hall, Upper Saddle River, New Jersey.

Jensen, J. R. and D. C. Cowen 1999. Remote sensing of urban / suburban infrastructure and socio-economic attributes. Photogrammetric Engineering and Remote Sensing 65(5): 611-622.

Johnston, R.J. 1991. A question of place: exploring the practice of human geography. Blackwell, Oxford, U.K.

Johnston, R.J. 2000. The Dictionary of Human Geography. Johnston, R.J, D. Gregory, G. Pratt and M. Watts eds. Blackwell Publishers, Malden, Massachusetts.

Khorram. S., Brockhaus, J. A., Chesire, H. M. 1987. Comparison of Landsat MSS and TM data for urban land-use classification. IEEE Transactions on Geoscience and Remote Sensing. GE-25(2): 238-243.

Lillesand, T. M. and R. W. Kiefer 2000. Remote Sensing and Image Interpretation. 4th ed. John Wiley \& Sons, New York.

Lillesand, T.M., R.W. Kiefer and J.W. Chipman 2004. Remote Sensing and Image Interpretation. 5th ed. John Wiley \& Sons, New York.

Littler, C.R. 1982. The development of the labour prossess in capitalist societies. Heinemann Educational Books, London.

Lunetta, R. S., Ed. 1999. Applications, Project Formulation, and Analytical Approach. Remote Sensing Change Detection: Environmental Monitoring Methods and Applications. Taylor and Francis, Inc., New York.

MacDonald, R. J. and D. Frew 1996. Home Port Erie, Voices of Silent Images. Erie Pa, Erie County Historical Society.

Mas, J. F. 1999. Monitoring land-cover changes: a comparison of change detection techniques. International Journal of Remote Sensing 20(1): 139-152.

Masek, J. G., F. E. Lindsay and S. N. Goward 2000. Dynamics of urban growth in the Washington D.C. metropolitan area, 1973-1996, from Landsat observations.

International Journal of Remote Sensing 21(18): 3473-3486. 
Merrifield, A. 1993. Place and space: a Lefebvrian reconciliation. Transactions Institute of British Geographers. 18, pp. 516-31

Massey, D. 1993. Power-geometry and a progressive sense of place. London, Routledge.

Massey, D. 1997a. A global sense of place. In Barnes, T and D. Gregory eds. Reading human geography: the poetics and politics of inquiry. Arnold, London.

Massey, D. 1997b. The political place of locality studies. In McDowell, L. eds. Undoing place? A geographical reader. Arnold, London.

Miller, J. 1909. A Twentieth Century History of Erie County Pennsylvania: A Narrative Account of its Historical Progress, its People, and its Principle Interests. Vol.1, The Lewis Publishing Company, Chicago

Mohr, M.C., Pope, J. and J.K. McClung 1999. Coastal response to a detached breakwater system; Presque Isle, Erie, PA, U.S.A. In Kraus, N.C and W.G. McDougal, eds Coastal Sediments '99. Vol. 2. American Society of Civil Engineers.

Monroe, J.S. and R. Wicander 2006. The Changing Earth: Exploring Geology and Evolution. 4th ed. Thomson Brooks / Cole. Belmont, CA

Moore, L. J. 2000. Shoreline mapping techniques. Journal of Coastal Research 16(1): 111-124.

Nolen, J. 1914. Greater Erie 1913, Plans and Reports for the Extension and Improvement of the City. Erie, Pennsylvania: Chamber of Commerce and Board of Trade.

Nummedal, D., D.L. Sonnenfeld and K. Taylor 1984. Sediment transport and morphology at the surf zone of Presque Isle, Lake Erie, Pennsylvania. Marine Geology. 60, 99-122.

Parson, L.E., Lillycrop W.J. and J.K. McClung 1999. Regional sediment management using high density LIDAR data. In Kraus, N.C. and W.G. McDougal, eds. Coastal Sediments '99. Vol. 2. . American Society of Civil Engineers.

Pennsylvania Historical and Museum Commission. The Battle of Lake Erie. http://www.phmc.state.pa.us/ppet/erie/page1.asp?secid=31.

Pilkey, O.H. and R. Thieler 1992. Erosion of the United States shoreline. In C.H. Fletcher III and J. Wehmiller eds. Quaternary coasts of the United States: Marine and lacustrine systems (pp. 3-7). SEPM Special Publication 48. Tulsa, Oklahoma: Society for Sedimentary Geology.

Pilkey, O.H and K.L. Dixon 1996. The Corps and the Shore. Island Press, Washington, DC. 
Pope, J. and R. J. Gorecski 1982. Coastal Geologic and Engineering History Presque Isle Peninsula, Pennsylvania. U.S. Army Corps of Engineers, Waterways Experiment Station. Buffalo, New York.

Pred, A. 1984. Place as historically contingent process: sturcturation and the timegeography of becoming places. Annals of the Association of American Geographers. 74 (2), pp. 279-97.

Raymond P. Schafer Highway I - 792008. http://www.pahighways.com/interstates/I79.html

Reed, J.E. 1925. History of Erie County Pennsylvania. Vol. 1. Historical Publishing Company; Indianapolis, Indiana.

Ritter, D.F., Kochel, R.C. and J.R. Miller 1995. Process Geomorphology. 3rd Ed. Wm. C. Brown. Dubuque, Iowa.

Ryznar, R. M. and T. W. Wagner 2001. Using remotely sensed imagery to detect urban change: Viewing Detriot from space. Journal of the American Planning Association 67(3): 327-336.

Sayer, A. 1986. New developments in manufacturing: the just-in-time system. Capital and Class. No. 30. 43-72.

Sayer, A. 1989. The 'new' regional geography and problems of narrative. Environment and Planning D: Society and Space. Vol. 7. 253-276

Schaney, C. R. 2003. The History of Presque Isle and the City of Erie: A Remote Sensing Case Study. Department of Geology and Geography. Morgantown, WV, West Virginia University. Master of Arts: 65.

Schoenberger, E. 1988. From fordism to flexible accumulation: technology, competitive stratagies, and international location. Environment and Planning D(6): 245-262.

Scott, A. 1997. The cultural economy of cities. International Journal of Urban and Regional Research 21(2): 323-329.

Shoshany, M. and A. Degani 1992. Shoreline detection by digital image processing of aerial photography. Journal of Coastal Research 8(1): 29-34.

Singh, A. 1989. Digital change detection techniques using remotely-sensed data. International Journal of Remote Sensing 10(6): 989-1003.

Smith, N. 1984. Uneven Development: Nature, Capital and the Production of Space. Blackwell Publishers, New York. 
Smith, N. 1996. The production of nature. in Future Natural. Robertson, G., Mash, M., Tickner, L., Bird, J., Curtis, B., and T. Putnam Eds. Routledge, London, New York.

Stransky, T.E., and Greene, B.H. 1989. Presque Isle Peninsula: A Case Study in Beach Cementation. Bulletin of the Association of Engineering Geologists. v. 26 pp. 3 325332

Swisher, C. 1979. The Erie Story. Clare Swisher Editorial Services. Erie, Pennsylvania. 6-9

Thieler, E. R. and W. W. Danforth 1994. Historical shoreline mapping (I): improving techniques and reducing positioning errors. Journal of Coastal Research 10(3): 549-563.

Thomas, D.J., Delano, H.L., Buyce, R.M., and Carter, C.H. 1987. 52nd Annual Field Conference of Pennsylvania Geologists. Harrisburg, Pennsylvania: Field Conference of Pennsylvania Geologists c / o Department of Environmental Resources. pp. 5-38.

Thomas, D.S.G. and N.J. Middleton 1994. Desertification: exploding the myth. Wiley, Chichester.

Toll, D. 1985. Effect of Landsat Thematic Mapper Sensor Parameters on

Land Cover Classification. Remote Sensing of the Environment. 17: 129-140.

United State Corps of Engineers, Great Lakes and Ohio River Division. Historical Overview: Great Lakes and Ohio River Division.

http://www.lrd.usace.army.mil/what_we_do/

United States Army Corps of Engineers 2001. Presque Isle Shoreline Erosion Control Project: Monitoring Data Summary to Fall 2001. Buffalo NY: U.S. Army Corps of Engineers.

United States Army Corps of Engineers 2007. November 2007 Great Lakes Water Level Summary. United States Army Corps of Engineers, Detroit District. Detroit, Michigan.

Urry, J. 1986. Capitalist production, scientific management and the service class. in Scott, A.J. and M. Storper Production, Work and territory. Allen and Unwin, Hemel Hempstead, Herts. 41-66.

Vallejo, L. E. and R. Degroot 1988. Bluff response to wave action. Engineering Geology 26(1): 1-16.

Vogelmann, J. E., T. Sohl and S. M. Howard 1998. Regional characterization of land cover using multiple sources of data. Photogrammetric Engineering and Remote Sensing 64(1): 45-75. 
Whitlark, F.L. 1959. Introduction to the Lakes: An Introduction to the Great Lakes and St. Lawrence Seaway. Greenwich Book Publishers, New York.

Williams, M.A.J., D. Dunkerley, P. De Deckker, P. Kershaw and J. Chappel 1998. Quaternary Environments 2nd Ed. Arnold, London.

Wilson, D. and J. Wouters 2003. Spatiality and Growth Discourses: The Restructuring of Americas Rust Belt Cities. Journal of Urban Affairs(25): 123-138.

Woodroffe, C. D. 2003. Coasts: Form Process and Evolution. Cambridge, Cambridge University Press.

Xiuwan, C. 2002. Using remote sensing and GIS to analyze land cover change and its impacts on regional sustainable development. International Journal of Remote Sensing. 23(1), pp. 107-124. 


\section{$\underline{\text { Appendix A }}$}

\section{Scanning Hydrographic Operational Airborne Light Detection and Ranging Survey (SHOALS)}

Developed in the mid-1980s and put into operation by the USACE in 1994, Scanning Hydrographic Operational Airborne Light Detection and Ranging (LIDAR) Survey (SHOALS) consists of an airborne data collection system and a ground based data processing system that conducts surveys on shoreline position as well as bathymetric surveys of the nearshore bottom (Parson et al, 1999). The pulsed laser transmitter consists both green and infrared (IR) out put beams (Guenther et al, 2000). Green is used because it is at a wavelength that can penetrate water (up to $60 \mathrm{~m}$ in clear water, or two to three times the visible depth) with the least amount of interference. IR laser pulses are sent simultaneously and are used to detect the water surface. The vertical accuracy measured for the SHOALS system was measured to be $0.28 \mathrm{~m}(.92 \mathrm{ft})$ at a 95 per cent confidence level. Horizontal accuracy is based on three components; the location of the aircraft, which is accomplished through the use of GPS, the location of the LIDAR surface spot with respect to the aircraft and the location of the LIDAR bottom spot with respect to the surface spot location (Guenther et al, 2000). The resulting image is represents the bathymetry of the nearshore bottom, which can be used not only to aid in delineating the shoreline position, but to also glean information on shoreline deposition and erosion associated with breakwaters (Parson et al, 1999). 


\section{$\underline{\text { Appendix B }}$}

\section{Satellite Imagery}

This research used two temporally distinct remotely sensed Landsat scenes. Landsat TM data has been found to be useful and effective when evaluating large areas such as metropolitan areas (Toll, 1985; Khorram et al, 1987; Vogelmann et al, 1998; Jensen and Cowen, 1999) and it has been found to be particularly useful when estimating land cover change across large metropolitan areas (Jensen, 1981; Fung, 1990; Masek et al, 2000; Ryznar and Wagner, 2001; Xiuwan, 2002).

The entire study area is within the Landsat scene Path 18, Row 31. Both scenes were acquired from the Ohio View website (www.ohioview.org). The first scene was captured on October 3, 1984 by theThematic Mapper (TM) instrument onboard the Landsat 5 satellite, measuring 7 multispectral bands. The second scene was captured on September 17, 2007, also by the TM instrument onboard the Landsat 5 satellite, measuring 7 multispectral bands. Both Images have a $30 \mathrm{~m}(98.4 \mathrm{ft})$ pixel resolution. Band combinations 1, 2 and 3 (blue, green and red) for both images were chosen for the analysis.

\section{Aerial Photography}

Aerial photography taken June 23, 1970 was acquired from Eros Data Center (www.eros.usgs.gov). Scale of the photography is 1:10,512.

Aerial photography taken June 4, 1977 was acquired from Eros Data Center (www.eros.usgs.gov). Scale of the photography is 1:80,000. 
Aerial photography taken May 11, 1983 was acquired from Eros Data Center

(www.eros.usgs.gov). Scale of the photography is 1:80,000

Aerial photography taken September 4, 1987 was acquired from Eros Data Center (www.eros.usgs.gov). Scale of the photography is 1:12,000.

Aerial photography taken April 7, 1993 was acquired from PASDA

(www.pasda.psu.edu). Scale of the photography is 1:12,000.

Aerial photography taken August 26, 2006 was acquired from PASDA

(www.pasda.psu.edu). Scale of the photography is 1:12,000.

\section{Software}

Several software packages were used in this research. Erdas Imagine was used to import subset and display TM imagery in a GIS environment. ArcGIS 9.0 and ArcView 3.3 were used to spatially assign data by location, query and display. Microsoft Excel was also used for additional formatting, analysis and display. 